\author{
UNIVERSIDADE DE SÃO PAULO \\ FACULdADE DE FILOSOFIA, LETRAS E CIÊNCIAS HuMANAS \\ DEPARTAMENTO DE GEOGRAFIA \\ Programa de Pós-Graduação em Geografia Humana
}

\title{
Geografia EleitoraL \\ Reforma Política e Uso do TERRITÓRIo BRAsILEIRo
}

Doraci Elias Zanfolin

Orientadora: Professora Doutora María Laura Silveira

Dissertação apresentada ao Programa de Pós-Graduação em Geografia Humana, do Departamento de Geografia da Faculdade de Filosofia, Letras e Ciências Humanas da Universidade de São Paulo, para obtenção do título de Mestre. 


\section{AGRADECIMENTOS}

Gostaria de agradecer a todos aqueles que compartilharam comigo essa caminhada.

Aos meus pais, Durvalino e Lavina, meus irmãos, sobrinhos e minha esposa.

Aos amigos, todos! Muito obrigado a cada um de vocês.

Agradeço à Capes pela bolsa de mestrado, fundamental para o desenvolvimento desta pesquisa.

O convívio acadêmico na Universidade - com os orientadores, professores dos cursos assistidos, professores, colegas e funcionários do Departamento de Geografia da Universidade de São Paulo.

À Professora Maria Adélia por me acompanhar durante toda este caminhar que se iniciou na época da graduação. Sem sua generosidade e, sobretudo, paciência não conseguiria realizar este trabalho. Seu amor pela geografia e seu conhecimento foram fundamentais em todos os momentos.

À Professora María Laura Silveira, por sua acolhida e generosidade, carinho e amizade. Sua dedicação à geografia e seus conhecimentos foram sempre referências valiosas durante toda à pesquisa. 


\section{Resumo}

Os partidos políticos participam do uso do território brasileiro disputando o controle de suas porções. Quando ganham um cargo, seja legislativo ou executivo, potencializam suas possibilidades de intervenção no território, participando da construção de novas materialidades, ora promovendo ora coibindo novos usos. Um novo sistema normativo, como é o caso da proposta de reforma política, pode significar outras possibilidades de uso do território pelos partidos políticos, beneficiando uns ou outros, porque estabelece novas regras para a concorrência eleitoral e para o financiamento das campanhas e quais alianças territoriais serão permitidas. Essas novas regulamentações podem influenciar, junto com outros fatores, futuras distribuições do poder dos partidos políticos pelo território.

Ao mesmo tempo, o território usado participa não só da criação dessas novas normas como da sua eficácia, caso sejam adotadas, determinando se as novas leis serão apenas formas vazias, que perpetuam o mosaico político-territorial vigente, ou se promoverão novos arranjos territoriais.

A reforma política não pode ser entendida como uma variável autônoma da regulamentação das ações político-partidárias, independentemente da totalidade do uso do território. As regulamentações, ou seja, as normas são mediadoras e mediadas pela relação intrínseca entre ação política e materialidade. Dessa forma, o intuito de nossa pesquisa foi o de buscar compreender algumas propostas da reforma política a partir do território e seu uso, participando do debate da geografia política e eleitoral.

PalAVRAS-Chave: uso do território, reforma política, normas e normatização do território, sistema político-eleitoral, geografia eleitoral 


\section{Abstract}

Political parties participate in the use of the Brazilian territory competing for the control of its portions. Winning a seat in the legislative body or a position in the executive branch increase exponentially their possibilities of intervention in such territory, allowing them to participate in the building of new materialities by either promoting or preventing its new use.

A new system of norms, as in the case of the political reform proposal, might turn into new possibilities for the use of territory by political parties yielding benefit to some because it establishes new rules for electoral competition as well as for campaign financing in which territorial alliances shall be allowed. These new regulations might influence, together with other factors, future distribution of the political parties' power over territory.

At the same time, the territory used takes part not only in the making of these new norms but also in its efficacy, when they are adopted, determining whether the new laws will be no more than empty forms which perpetuate the prevailing political territorial mosaic, or they may promote new territorial organization.

The Political Reform should not be seen as an independent variable of the setting of norms of the political parties' actions, apart from the totality of territorial use. Norms are both mediators and mediated by the intrinsic relation between political action and materiality. Thus, the objective of this study was to reach an understanding of some political reform proposals based on territory and its use and by so doing, take part in the debate concerning political and electoral geography.

KEY WORDS: use of territory, political reform, norms and setting of norms of territory, political-electoral system, electoral geography. 
ÍNDICE

APRESENTAÇÃO

INTRODUÇÃO

Capítulo 1: Uma periodização do uso do território brasileiro pelo sistema eleitoral

1.1. A integração nacional e a nacionalização dos partidos políticos

1.2. A instalação do meio técnico-científico sob a centralização política do território

1.3. A retomada da democracia e a recomposição da diversidade políticapartidária no uso do território

Capítulo 2: O período atual

2.1. A geografia eleitoral da globalização e novas formas de uso corporativo do território

2.2. A informatização das eleições e modernização do território

2.3. A atual regulamentação do sistema político-eleitoral brasileiro e as primeiras propostas de reforma política

2.4. A cláusula de desempenho e as conseqüências territoriais para a geografia partidária brasileira

Capítulo 3: Reforma política e uso do território

3.1. Algumas propostas e suas intencionalidades

3.2. Territorialização do voto e a questão das listas pré-ordenadas

3.3. Voto distrital, só o enunciado é territorial? 
3.4. Financiamento público de campanha: uma tentativa de minimizar os usos corporativos do território

3.5. Nacionalização do partidos e a proporcionalidade territorial das 69 representações políticas

CONCLUSÃO

BIBLIOGRAFIA

GLOSSÁRIO

1. Sistemas Eleitorais

1.1. Sistema majoritário

1.2. Sistema proporcional

1.3. Sistema misto

Anexos

ANEXO 1: Doações da Empresa Itaú na Campanha Eleitoral - 2002

ANEXo 2: Doações da ARACRUZ CELULOSE S.A. na Campanha Eleitoral 2002

ANEXo 3: Doações da CONSTRUTORA NORBERTO ODEBRECHT S.A. na Campanha Eleitoral - 2002

ANEXO 4: Doações da CONSTRUTORA NORBERTO ODEBRECHT S.A. na Campanha Eleitoral - 2002 


\section{ÍNDICE DE TABELAS}

Tabela 1: Presidentes da República Eleitos - 1945-1960

Tabela 2: Presidentes da República Eleitos - 1989-1998

Tabela 3: Resultado Eleitoral de 1998 - Eleição para a Câmara dos

Deputados Federais

Tabela 4: Resultado Eleitoral de 2002 - Eleição para a Câmara dos

Deputados Federais

Tabela 5: Doações da CONSTRUTORA NORBERTO ODEBRECHT S.A. por

partido na Campanha Eleitoral - 2002

Tabela 6: Doações da CONSTRUTORA NORBERTO ODEBRECHT S.A. por tipo de Candidatura na Campanha Eleitoral - 2002

Tabela 7: Doações da CONSTRUTORA NORBERTO ODEBRECHT S.A. por

Estado na Campanha Eleitoral - 2002

Tabela 8: Doações das CONSTRUÇÕES E COMERCIO CAMARGO CORREIA SA na Campanha Eleitoral - 2002

Tabela 9: Doações do BANCO ITAÚ por Estado na Campanha Eleitoral 2002

Tabela 10: Doações do BANCO ITAÚ por tipo de Candidatura na Campanha Eleitoral - 2002

Tabela 11: Doações do BANCO ITAÚ por Partido na Campanha Eleitoral 2002

Tabela 12: Doações da ARACRUZ CELULOSE S.A. na Campanha Eleitoral 2002 


\section{APRESENTAÇÃo}

Pretendemos com esta dissertação de mestrado dar continuidade à pesquisa iniciada no final da graduação (realizada no Departamento de Geografia da Universidade de São Paulo) que resultou no TGI (Trabalho de Graduação Individual) "Geografia eleitoral, voto eletrônico e visibilidade do poder no território brasileiro", desenvolvido sob a orientação da Professora Doutora Maria Adélia de Souza.

No referido trabalho (TGI) buscamos enfocar a informatização das eleições como sendo um fenômeno possível de ser compreendido a partir de uma leitura geográfica, enxergando-o através de conceitos como território e poder. Desse modo, procuramos entender o significado dessa informatização para o território, considerando-a como um fenômeno do período atual.

A informatização das eleições participava, naquele momento histórico da década de 1990, de um conjunto de modernizações relativas ao sistema político eleitoral e do discurso da modernização do território.

Nosso objetivo era estudar um aspecto da modernização política no território brasileiro analisada pelo prisma eleitoral. Dessa forma não era o sistema eleitoral per si que estávamos estudando, mas a implicação de uma modernização do território através de novos objetos técnicos e novas formas do fazer eleitoral sobre a manutenção do poder político e poder territorial, que são sinônimos em nossa história. Isto porque nosso edifício metodológico fundava-se na equivalência que M. Santos faz entre as noções de território usado e espaço geográfico. Segundo o autor (1994, p. 16) "o território usado são objetos e ações, sinônimo de espaço humano, espaço habitado".

O estabelecimento desta equivalência permitiu-nos trabalhar com o conceito de território usado, enquanto um conjunto indissociável de sistemas de objetos e sistemas de ações (M. Santos, 1991; 1996, p. 51), em permanente movimento.

De um lado as ações criam, constróem e utilizam os objetos (naturais e artificiais) e, de outro, os objetos viabilizam e autorizam esta ou aquela ação. "Sistemas de objetos e sistemas de ações interagem. De um lado, os sistemas de 
objetos condicionam a forma como se dão as ações e, de outro lado, o sistema de ações leva à criação de objetos novos ou se realiza sobre objetos preexistentes. É assim que o espaço encontra sua dinâmica e se transforma" (M. Santos, 1996, p. $52)$.

A partir desta compreensão do território, podíamos enxergar como um novo sistema de objetos modernos, as urnas eletrônicas, participava em novas formas de ações, novos modos de fazer as eleições. O controle da apuração dos votos mudava de local e de mãos; os resultados das eleições ganharam rapidez diminuindo assim os tempos de especulação quanto à nova constituição do poder político no território - aspecto bastante interessante para os setores hegemônicos da sociedade, sedentos por velocidade, dependentes das políticas estatais -, e, também, a organização informatizada dos financiamentos das campanhas e disponibilizada para a consulta pública, entre outros.

Ainda durante essa pesquisa nos defrontamos com a discussão sobre uma nova proposta de regulamentação do sistema político-partidário e eleitoral do país. Ficava evidente que o processo de modernização do sistema político-eleitoral não se limitava a informatização das eleições mas também incluía a implantação de novas normas de funcionamento do sistema político-eleitoral. As propostas de reforma política, seja a questão das formas de representatividade, da expressão nacional mínima dos partidos políticos ou do financiamento público ou das campanhas, tanto são resultado de um dado arranjo territorial do poder político-eleitoral vigente como podem significar novas possibilidades ou não de uso do território brasileiro pelos partidos políticos.

A opção de um país por um determinado sistema político e eleitoral viabiliza a implementação de um projeto de uso do território, condizente com os interesses de uma parcela dos agentes sociais que o escolheram. Por essa razão, decidimos trabalhar em nossa pesquisa de Mestrado o sistema de ações que pretende mudar o sistema político-eleitoral e, conseqüentemente, a estruturação do território para receber esse sistema eleitoral, depois de um primeiro momento de modernização do território relativa ao sistema eleitoral atual que aconteceu com a informatização do território para as eleições. 


\section{INTRODUÇÃO}

O surgimento, nesta última década, de novas propostas de regulamentação do sistema político-eleitoral brasileiro oferece um panorama instigante sobre os novos rumos da geografia do poder dos partidos políticos nacionais e o uso do território que promovem ou que almejam através das eleições.

A reforma política, entre as reformas anunciadas seja pelo governo Fernando Henrique como pelo atual governo, aparece hoje como uma prioridade. Todavia, a proposta apresentada pela Comissão Especial de Reforma Política estava parada na Comissão de Constituição e Justiça desde 2004, esperando parecer desta comissão para ser enviada ao plenário da Câmara dos Deputados. Isso só ocorreu no final do primeiro semestre de 2005, por conta da crise política desencadeada pela denuncia de compra de votos de Deputados da base aliada ao governo para votar nos seus projetos enviados a Câmara dos Deputados.

Acreditamos que a modernização do sistema político em curso, como aconteceu com a modernização do voto através da urna eletrônica, contribui para um novo arranjo na cultura política, na estrutura de poder e nos usos do território que viabiliza ou inibe. Daí, nossa preocupação em analisar as atuais propostas de reforma do sistema político eleitoral brasileiro a partir do uso efetivo do território pelo sistema eleitoral e quais novas formas de usos podem ser possibilitadas ou freadas, significando modificação ou manutenção da atual territorialização do poder político.

Por estas razões, o intuito de nossa pesquisa de mestrado, nascida do Trabalho de Graduação Individual, é o de compreender os impactos da reforma política (em algumas de suas propostas) na disputa pelo uso do território promovida pelos partidos políticos nacionais.

O conceito de território possui muitas definições dentro da Geografia, e é considerado por vários autores como central para os estudos geográficos. Uma das definições mais freqüentes é aquela onde o território aparece como a área de um Estado, fixando os limites político-administrativos de sua atuação soberana. M. C. Andrade (1995, p. 19) coloca que "o conceito de território não deve ser confundido com o de espaço ou de lugar, estando muito ligado à idéia de domínio ou de gestão 
de determinada área". Para o autor a noção de território é relacionada à noção de instância político-administrativa.

Buscamos, contudo, trabalhar com a concepção de território usado de $\mathrm{M}$. Santos (1994a, 1998, 2001). Para o autor, a importância de se estudar uma dada situação ou fenômeno através do território está no uso que se faz do território, e não na análise do território em si (1994a, p. 15). "É o uso do território, e não o território em si mesmo, que faz de objeto de análise social. Trata-se de uma forma impura, um híbrido, uma noção que, por isso mesmo, carece de constante revisão histórica. O que ele tem de permanente é ser nosso quadro de vida". O território usado pressupõe "a interdependência e a inseparabilidade entre a materialidade, que inclui a natureza, e seu uso, que inclui a ação humana, isto é, o trabalho e a política" (M. Santos e M. L. Silveira, 2001, p. 247).

Para M. A. A. de Souza (2003, pp. 17-18), "o conhecimento do território tornou-se indispensável dada a sua importância nos processos de globalização e fragmentação que se verificam no mundo contemporâneo. O território, modernamente, é entendido não apenas como limite político administrativo, senão também como espaço efetivamente usado pela sociedade e pelas empresas. $O$ território tem, pois, um papel importante na formulação social brasileira, havendo ainda muito pouca compreensão sobre essa dimensão nova dos estudos a seu respeito. É bom lembrar que tudo passa, mas os territórios, espaços efetivamente usados, permanecem".

Apesar de C. Raffestin (1993) diferenciar espaço de território, sua definição de território ajuda-nos também a compreender como o uso do território é constituído de usos conflitantes, conformando o território num campo de relações de poder. Para C. Raffestin (1993, p.60), "o território é o espaço político por excelência". Diferenciando espaço de território, coloca que "o território se forma a partir do espaço, é o resultado de uma ação conduzida por um ator sintagmático (ator que realiza um programa) em qualquer nível. [...] O território, nessa perspectiva, é um espaço onde se projetou um trabalho, seja energia e informação, e que, por conseqüência, revela relações marcadas pelo poder" (p 143). Na diferenciação entre espaço e território, proposta por C. Raffestin (1993, p.144), o território aparece como 
sendo "uma produção a partir do espaço". A produção congrega um conjunto de relações, que por sua vez são a manifestação do poder. Desse modo, território e poder são intrinsecamente ligados: "ora, a produção, por causa de todas as relações que envolve, se inscreve num campo de poder. Produzir uma representação do espaço já é uma apropriação, uma empresa, um controle, portanto, mesmo se isso permanece nos limites de um conhecimento. Qualquer projeto no espaço que é expresso por uma representação revela a imagem desejada de um território, de um local de relações" (p.144).

As instituições - junto com os objetos, as empresas e as pessoas participam da constituição do território usado (M. Santos, 1994), e competem entre si para usá-lo. Os partidos políticos também disputam pelo uso do território, pesando seus diferentes tamanhos e forças (política, financeira e informacional) nesse campo de forças que se estabelece. Daí, não é possível entender a reforma política sem relacioná-la com a disputa pelo território promovida pelos partidos políticos.

As atuais propostas de reforma política revelam o jogo do poder dos partidos políticos pelo uso do território. Algumas propostas demonstram claramente uma vontade de fortalecimento dos grandes partidos, coincidentemente os defensores de muitas das atuais propostas de modificação do sistema políticoeleitoral atual. E, a reforma política não pode ser entendida como uma variável autônoma da regulamentação das ações político partidárias, independentemente da totalidade do uso do território. As regulamentações, ou seja, as normas são mediadoras e mediadas pela relação intrínseca entre ação política e materialidade.

Enfocando a relação território usado e as normas eleitorais preocupamo-nos com a seguinte perspectiva: quais usos do território, do ponto de vista da distribuição e representatividade do poder político, serão promovidos com as novas regulamentações eleitorais propostas? E, qual é a utilidade da Reforma política à sociedade como um todo, ao espaço com todos os seus lugares?

Buscamos compreender possíveis implicações, no caso da implantação de cada uma das novas regulamentações propostas, para o uso eleitoral do território e, também, para a geografia do poder dos partidos políticos. Como se delineará o 
campo de forças dos partidos políticos no uso do território brasileiro se estas normas forem adotadas? Em que se baseiam os argumentos favoráveis e contrários à implantação de algumas das propostas do atual Projeto de Reforma Política? Quais partidos os defendem e quais os recusam? Quais deles serão beneficiados e quais prejudicados? Estas são algumas indagações que nortearão a pesquisa que estamos desenvolvendo.

Para nos inserirmos neste debate, procuramos compreender o conceito de normas que, mesmo sendo um conceito originariamente externo a disciplina geográfica, torna-se, sobretudo no período contemporâneo, um dado interno do território. Isto porque as normas, para M. Santos (1996, p. 19), devem ser reconhecidas no estudo das categorias analíticas internas ao espaço geográfico. "Molde para a ação, a norma, em decorrência, é criadora de território, mas este também constitui, através do seu uso, uma norma para a ação" (M. L. Silveira, 2000, p. 121). Para M. Santos (1996, p. 64), "a ação é subordinada as normas, escritas ou não, formais ou informais e a realização do propósito reclama sempre um gasto de energia. A noção de atuação liga-se diretamente à idéia de praxis e as práticas são atos regularizados, rotinas ou quase rotinas que participam da produção de uma ordem".

Buscaremos, então, entender a Reforma Política como parte de um conjunto de normas formais e escritas, resultado de interesses políticos conflitantes, que buscam regularizar as práticas eleitorais da sociedade nos regimes democráticos buscando modificar ou manter uma determinada ordem.

As normas relativas a uma reforma política referem-se a modificações no sistema político em seus vários aspectos. O sistema político abrange a forma e o regime de governo de um país (presidencialista, parlamentarista etc.), o funcionamento e características das esferas legislativa e judiciária do Estado, a organização político-administrativa do país (sistema federativo, centralizado etc.), modalidades diversas de integração entre Estado e sociedade, as instituições 
políticas partidárias ${ }^{1}$ e da sociedade civil, a cultura política ${ }^{2}$ o sistema eleitoral e sua normatização.

Segundo M. Santos (1996, pp.181-182), a norma participa do espaço geográfico como um dos elementos mediadores entre o sistema de objetos e o sistema de ações. "O fato de o sistemismo dos objetos condicionar o sistemismo das ações não significa que entre eles haja relação automática. Existem mediações e, entre elas, a lei, as normas, os costumes, a religião, as representações herdadas ou ensinadas. Mas a interação humana pode forjar novas relações, criando a surpresa e impondo novidade".

Desse modo, as normas vistas isoladamente não explicam o espaço, uma vez que elas apenas são um dos seus elementos (M. L. Silveira, 2003). A preocupação em não se perder um enfoque totalizador é muito importante para se revelar a fragilidade do discurso político que coloca a Reforma Política como solução para todos os problemas do sistema político-eleitoral brasileiro atual.

Quando procuramos entender a Reforma Política pela dinâmica do território e seu uso, estamos preocupados com a questão da totalidade. Segundo M. Santos (1992, 1985, p. 10) "o valor da variável não é função dela própria, mas do seu papel no interior do conjunto". "Fatos isolados são abstrações e o que lhes dá concretude é a relação que mantém entre si” (1992, 1985, p. 14). Destaca-se então a existência de ligações orgânicas entre as partes e o todo, que se dão através de interações.

Para K. Kosik (1976, 1963, p. 25), "cada objeto percebido, observado ou elaborado pelo homem é parte de um todo, e precisamente este todo não percebido

\footnotetext{
${ }^{1}$ As instituições políticas são o traço essencial das democracias modernas, constituindo-se "no equacionamento de duas ordens de questões. Por um lado, lograram as democracias definir regras de participação política, sobretudo através do voto, que levaram à progressiva implantação do sufrágio universal; por outro, criaram uma matriz de instituições com vistas a regular a competição política. O ideal democrático implica, assim, no campo das possibilidades históricas, a obtenção de graus crescentes de representatividade, legitimidade e eficácia governamental” (O. B. Lima Júnior, 1997, pp. 113-114).

${ }^{2}$ A cultura política são as relações entre os agentes políticos propriamente ditos: cidadãos, eleitores, candidatos, partidos, mídia etc. A cultura política é entendida como uma variável do sistema político de fundamental importância para a consolidação do regime democrático. Contudo, para J. A. Moisés (1995, p. 97), a eficácia da consolidação democrática "depende, entre outras coisas, do modo como o pacote institucional democrático é formulado e apresentado tanto às elites 'relevantes' como à massa dos cidadãos, com vista à obtenção do seu consentimento; mas as escolhas sobre a estrutura política não se separam do terreno em que convicções, influências e tradições simbólicas informam a ação dos atores que fazem essas escolhas".
} 
explicitamente é a luz que ilumina e revela o objeto singular, observado em sua singularidade e no seu significado".

Por sua vez, M. Santos (1996, p. 96) nos alerta que "para se alcançar a verdade total, é necessário reconhecer o movimento conjunto do todo e das partes, através do processo de totalização". A totalidade não é um simples somatório de pedaços autônomos. Cada uma das partes que integra um todo só possui sentido se remetida ao todo que a atinge e que por elas é atingido e transformado. Para se alcançar a totalidade social é fundamental o reconhecimento e o estudo das interações que se dão entre suas partes - que são também totalidades menores. Estas não se explicam em si, mas somente em relação ao todo. Para M. Santos (1992, 1985, p. 7), "através do estudo das interações, recuperamos a totalidade social, isto é, o espaço como um todo e, igualmente, a sociedade como um todo. Pois cada ação não constitui um dado independente, mas um resultado do próprio processo social".

Para finalizar, acreditamos que o tema de nosso trabalho se insere dentro do campo da Geografia Eleitoral, e conseqüentemente, como defendem muitos autores, um ramo da Geografia Política ${ }^{3}$.

Segundo P. J. Taylor (1994, p. 215) existe um debate, com posições completamente antagônicas, sobre a geografia eleitoral. De um lado, estão aqueles

\footnotetext{
${ }^{3}$ Um dos marcos fundacionais da Geografia Política seria a publicação, em 1897, na Alemanha, da obra Politische Geographie de autoria do geógrafo F. Ratzel (1844-1904), que influenciou não só a escola alemã, como também outras escolas de geografia, como a francesa e a norte-americana.
}

Para A. Sanguin (1977, pp. 6-7), os trabalhos do geógrafo alemão vão além da simples preocupação em se produzir uma geografia voltada para o Estado. Defende que "a inovação radical da análise ratzeliana é sua concepção de Estado como um organismo biológico vivo que nasce, cresce e declina. O desenvolvimento da teoria orgânica sobre o Estado é apenas uma parte do livro de Ratzel. O restante, isto é, o crescimento e a natureza das unidades políticas, suas fronteiras e seu acesso ao mar, é analisado em um sentido sistêmico e crítico ao mesmo tempo".

A importância do trabalho de F. Ratzel para a geografia política é reconhecida, também, pelo geógrafo C. Raffestin (1993, pp. 13-14), que considera ainda hoje relevantes vários dos seus apontamentos conceituais. Segundo o autor, F. Ratzel "concentrou os seus esforços nos conceitos espaciais e, em particular, na posição, que é um dos conceitos fundamentais da geografia política. Também as fronteiras, na qualidade de órgão periférico do Estado, durante muito tempo prenderam sua atenção (...). Da mesma forma, não negligenciou o estudo da população e da circulação, concebida como movimento dos seres e das coisas. (...) o crescimento diferencial, o centro e a periferia, o interior e o exterior, a vizinhança, entre outros". Todavia, critica duramente a falta de avanço teórico dos trabalhos de geografia política posteriores ao do geógrafo alemão: "Se Ratzel abrisse hoje os manuais de geografia política geral, não se sentiria deslocado - exceto por algumas fórmulas e índices, pois encontraria as categorias de análise utilizadas ou forjadas por ele. Essas categorias de análise seriam, aliás, procedentes, direta ou indiretamente, de um único conceito, o de Estado" (C. Raffestin, 1993, p.14). 
que a consideram como o núcleo da Geografia Política. De outro, encontram-se os que a defendem como não sendo parte da Geografia Política. Contudo, o autor ressalva que qualquer "postura que se adote neste debate depende, em última instância, da definição de geografia política que se está utilizando". Dentro deste debate, argumenta que geografia política das eleições tem um papel chave na escala da ideologia, defendendo que os estudos de geografia eleitoral sejam feitos de uma forma diferente daqueles trabalhos de geografia eleitoral com influência da geografia quantitativa. Segundo ele, grande quantidade de trabalhos acerca da geografia eleitoral peca por ser análises isoladas, que examinam uma dada eleição de modo autônomo.

Para W. M. da Costa (1992, p. 261), a geografia eleitoral passou a fazer parte dos novos temas da geografia política da década de 1970, assim apontados pelo autor: "os novos temas da geografia política, tais como a análise da gestão administrativa interna dos espaços nacionais em seus vários níveis, a organização do poder público, o problema da autonomia regional e local, o comportamento político-eleitoral das diversas regiões, etc., passaram a ser abordados com maior insistência a partir de meados da década, por vários autores”.

Na história do pensamento geográfico, a Geografia Eleitoral tem como um de seus pioneiros o geógrafo A. Siegfried, da escola francesa de geografia. A. Siegfried publica, em 1913, seus estudos sobre a França Ocidental e a Terceira República, considerado um clássico da Geografia Eleitoral (P. J. Taylor, 1994, p. 216). Sua preocupação era a de comparar e explicar os distintos resultados eleitorais, utilizando-se de cartografia temática tanto para fatores explicativos quanto para os resultados eleitorais. Em 1918, C. Sauer teve, também, importante contribuição para a fundação da geografia eleitoral, criando a escola americana de Geografia Eleitoral (P. J. Taylor, 1994, p. 216). Nessa época, contribuiu para o debate norte-americano sobre como definir os distritos para as eleições ao Congresso, sugerindo uma representação por regiões geográficas.

As cartas eleitorais, que desde as primeiras décadas do século $\mathrm{XX}$, tão presentes nos estudos de geografia eleitoral, serão também neste trabalho um importante instrumental de pesquisa. Contudo, como já insistia F. Goguel em 1951, é 
necessário preocupar-se mais com os aspectos explicativos do que com os descritivos. Para o autor (F. Goguel, 1991, p. 43), "estudar um fenômeno social, a sociologia eleitoral, que não implica o abandono da noção de geografia mas seu aprofundamento, permite pesquisar os fatores de estrutura social, eles mesmos diferenciados no espaço, que correspondem à repartição espacial de opiniões políticas" (p. 43). Observava, também, que certos trabalhos de geografia humana da década de 1950 foram identificados como mais sociológicos do que geográficos e a geografia humana, "até uma certa época, ignorou totalmente os fenômenos eleitorais" (p. 44). Entre as duas Guerras Mundiais, para ele, houve um maior interesse junto às Ciências Sociais por uma dimensão geográfica das questões eleitorais. Outros autores importantes, como A. Siegfried e de C. Sauer, no início do século XX (1913 e 1918, respectivamente), contribuíram para a produção intelectual sobre geografia eleitoral.

Com o aparecimento da geografia quantitativa, em meados do século $X X$, os estudos de geografia eleitoral sofreram mudanças qualitativas e as cartas eleitorais ganharam ênfase nos estudos eleitorais. "A publicação regular de diversas séries de dados eleitorais, ordenados de forma clara por áreas, proporcionou uma grande quantidade de material aos novos geógrafos de orientação quantitativa (Taylor, 1978); motivo pelo qual houve um aumento extraordinário de estudos eleitorais" (P. J. Taylor, 1994, p.217). Todavia, durante a década de 1980, a obra dirigida por Y. Lacoste, Géopolitique des régions françaises (1986), inaugura uma análise de resultados eleitorais integrando os aspectos histórico e espacial (F. Goguel, 1991). E, recentemente, o próprio F. Goguel (1991, p. 46) defende que "não podemos nos contentar em analisar os resultados eleitorais, é preciso examinar igualmente as estruturas sociais correspondentes".

Acreditamos que os estudos de geografia eleitoral são, antes de tudo, estudos geográficos. Os sistemas político e eleitoral, enquanto estrutura de poder, proporcionam determinadas possibilidades de uso do território. Isso ocorre porque o território é constituído pelos agentes sociais, com interesses diversos, com projetos de sociedade antagônicos, muitas vezes diametralmente opostos. As diferentes 
intencionalidades implicam em construções de modelos de mundo muito distintos e, conseqüentemente, distintas formações socioespaciais. 


\section{Capítulo 1: Uma periodização do uso do território brasileiro pelo sistema eleitoral}

Os objetos e normas, técnica e política são fenômenos históricos e a cada momento, tanto os sistemas técnicos quanto os normativos, autorizam uma diferente constituição e uso do território.

No espaço geográfico convivem objetos e normas de idades diversas, sendo possível datá-los, uma vez que a técnica e a política são fenômenos históricos. A datação do momento de origem ou de instalação de objetos e ações pode ser feita à escala do mundo, de um país, uma região ou um lugar. A periodização permite encontrar a existência e o valor das diferentes variáveis nos distintos momentos da história, sendo possível enxergar o que é de fato novo e o que permanece como herança no período atual.

Segundo O. B. Lima Júnior (1997, p. 114), "duas têm sido as formas históricas de mudança política: o progressivo aperfeiçoamento das instituições a partir e dentro de uma matriz original, ou a ruptura com o arranjo institucional prevalecente seguida da implantação de novas instituições que diferem significativamente do conjunto já existente". Essas mudanças são promovidas por diferentes processos, que podem ser também as transformações via normatização específica do sistema político-eleitoral, que alteram o molde para as ações políticoeleitorais.

A legislação que incide sobre o sistema político-eleitoral, é um conjunto de leis, amiúde aprovadas pelo poder legislativo, caracterizando-se como um conjunto de regras que definem os vários aspectos do sistema político e a forma de funcionamento do sistema eleitoral, estabelecendo as formas de representação, de realização do pleito, entre outros aspectos.

Sendo um dos elementos do sistema político de um país, os sistemas eleitorais são construções institucionais políticas e estrategicamente concebidas, e tecnicamente realizadas, para viabilizar e sancionar a representação política em 
regimes políticos ${ }^{4}$. Desse modo, sistema eleitoral e representação política não são sinônimos; ele viabiliza uma relação entre sociedade e seus representantes.

O sistema eleitoral pode ser entendido como o procedimento de escolha dos representantes que devem ocupar, no caso do Brasil, as cadeiras no legislativo (senadores, deputados federais, deputados estaduais e vereadores) ou chefia do executivo (presidente da república, governadores de estado e prefeitos dos municípios).

As tipologias dos sistemas eleitorais são numerosas e complexas nos seus detalhes e minúcias técnicas, sendo diferentes os modelos adotados pelos diversos países do mundo. Existe, no entanto, um certo consenso, por parte dos especialistas, sobre a existência de dois grandes modelos de representação: o sistema majoritário e o sistema proporcional, havendo também, um terceiro, que é um híbrido desses dois, conhecido como sistema misto (ver definições de cada sistema no glossário).

A modernização, através das normas, pode significar autorizações no fazer político de um país, alterando ou mantendo jogo de forças na disputa política pelo uso do território, sobretudo aquela promovida pelos partidos políticos.

Os partidos, enquanto instituições, usam o território e o disputam de acordo com sua força, tamanho e poder.

Para D. Nohlen (1994, p. 38), o sistema partidário é composto pela totalidade dos partidos políticos de um Estado. Refere-se à quantidade dos partidos, seus tamanhos, suas pautas de ações, sua composição ideológica e social e sua participação no sistema político.

\footnotetext{
4 "A representação política é uma relação entre o conjunto dos cidadãos que integram uma comunidade política nacional e os seus representantes, na qual os primeiros, enquanto comitentes e constituintes, autorizam os últimos a tomarem as decisões que obrigam em comum e universalmente a todos, nelas consentido por antecipação e assumindo, cada um, todas as conseqüências normativas derivadas das decisões do corpo de representantes como se as tivesse efetiva e pessoalmente adotado, e na qual, por outro lado, cada um dos representantes se obriga a tornar efetivos, no corpo legislativo, ao mesmo tempo, os valores fundamentais e comuns da ordem política e as concepções particulares acerca do interesse e do bem público daquele conjunto especial de constituintes que, com sua confiança, concorreram pra a consecução de seu mandato" (J. A. G. Tavares, 1994, p. 33)
} 
O cientista político brasileiro J. M. Nicolau (1996, p.9-10) agrega as diversas definições de partidos políticos em dois tipos: ampla e restrita. "As definições amplas procuram dar conta de todas as dimensões do fenômeno partidário: organizações que atuam na arena eleitoral em países democráticos, partidos únicos dos regimes fechados, partidos militantes (religiosos, étnicos, regionais, ideológicos) que operam à margem do sistema político com ação extraparlamentar". Já as definições restritas "preocupam-se exclusivamente com a dimensão competitiva; ou seja, partidos são organizações que participam das eleições em países democráticos”. O autor, citando A. Panebianco (1988, p. 6), ainda ressalva que os partidos políticos acabam adquirindo um monopólio da atividade eleitoral nas democracias contemporâneas, uma vez que eles " 'são os únicos que operam na arena eleitoral, na qual competem por votos' " (J. M. Nicolau, 1996, pp.9-10).

Segundo a definição de M. Weber, citada por N. Bobbio (1995, p. 898), o partido político é uma associação “que visa a um fim deliberado, seja ele 'objetivo' como a realização de um plano com intuitos materiais ou ideais, seja 'pessoal', isto é, destinado a obter benefícios, poder e, conseqüentemente, glória para os chefes e sequazes, ou então voltado para todos esses objetivos conjuntamente".

Para tornar mais concreta e específica esta definição de M. Weber, N. Bobbio (1995, pp. 898-899) coloca que "é usual sublinhar que as associações que podemos considerar propriamente como partidos surgem quando o sistema político alcançou um certo grau de autonomia estrutural, de complexidade interna e de divisão do trabalho que permitam, por um lado, um processo de tomada de decisões políticas em que participem diversas partes do sistema e, por outro, que, entre essas partes, se incluam, por princípio ou de fato, os representantes daqueles a quem as decisões políticas se referem. Daí que, na noção de partido, entrem todas as organizações da sociedade civil surgidas no momento em que se reconheça teórica ou praticamente ao povo o direito de participar na gestão do poder político. É com este fim que ele se associa, cria instrumentos de organização e atua”.

Ainda, para o autor, em termos gerais, o nascimento e o desenvolvimento dos partidos relacionam-se ao problema da demanda de participação no processo de formação e tomada de decisões políticas. "Tal demanda de participação se 
apresenta de modo mais intenso nos momentos das grandes transformações econômicas e sociais que abalam a ordem tradicional da sociedade e ameaçam modificar as relações do poder. É em tal situação que emergem grupos, mais ou menos amplos e mais ou menos organizados, que se propõem agir em prol de uma ampliação da gestão do poder político a setores da sociedade que dela ficavam excluídos ou que propõem uma estruturação política e social diferente da própria sociedade. Naturalmente, o tipo de mobilização e os estratos sociais envolvidos, além da organização política de cada país, determinam em grande parte as características distintivas dos grupos políticos que assim se formam" (N. Bobbio, 1985, p. 899).

Desse modo, os partidos políticos têm se mostrado, no decorrer do seu desenvolvimento histórico, como um instrumento importante de participação política da sociedade, em seus diversos segmentos.

Para N. Bobbio (1995, p. 904) aos partidos são reconhecidas duas funções: a de transmissão do questionamento político da sociedade (que são todas aquelas atividades dos partidos que têm como objetivo fazer com que as decisões políticas levem em consideração certas necessidades da sociedade) e a de possibilitar a participação das massas no processo de formação das decisões políticas (que são aqueles "atos como a organização das eleições, a nomeação de pessoal político e a competição eleitoral"). É através dessa função que "o partido se constitui sujeito de ação política e é delegado para agir no sistema a fim de conquistar o poder e governar".

Uma breve retomada de alguns períodos da história política brasileira, a partir de alguns aspectos da legislação eleitoral e dos sistemas partidários e eleitoral, será importante para a compreensão do período atual.

\subsection{A integração nacional e a nacionalização dos partidos políticos}

Para o entendimento do atual funcionamento do sistema partidário brasileiro decidiu-se por um corte histórico a partir de 1945. Neste ano a Justiça Eleitoral é restabelecida no país e, com o fim do Estado Novo, de acordo com Rogério Schmitt 
(2000, p. 7), criam-se as possibilidades para o surgimento dos primeiros partidos de

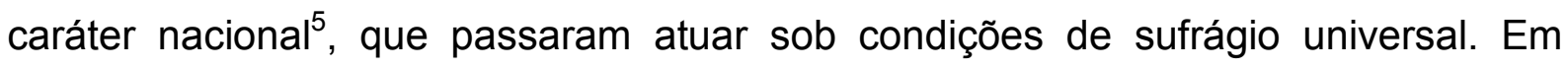
1946, a Constituição, promulgada em 18 de setembro, consagrou a exigência do caráter nacional para os partidos políticos e estabeleceu eleições diretas para presidente e vice-presidente, simultâneas, porém independentes.

Junto à crise do Estado Novo, aumentava o número de partidos e surgiam novos pactos e novas relações de poder no território brasileiro. Segundo E. L. Ferreira Neto (1995, p. 20), os partidos "surgidos após 1945 estarão compreendidos dentro de uma sociedade com uma complexidade maior e imersa numa comunidade capitalista internacional mais desenvolvida". Alguns partidos possuíam caráter de massa e pretendiam representar os diversos segmentos da sociedade.

O Partido Comunista Brasileiro (PCB), a mais antiga organização partidária do país (fundada em 1922) foi legalizada pela primeira vez em 1945. Todavia, em maio de 1947, teve o seu registro eleitoral cancelado pelo Tribunal Superior Eleitoral, por razões ideológicas. Todos os parlamentares pecebistas tiveram os seus mandatos cassados.

A consagração do caráter nacional dos partidos políticos coincidia com o início da integração do mercado e do território nacionais, dada por uma fluidez potencial (presença de infra-estruturas) e fluidez efetiva (dada pelo uso) (M. Santos e M. L. Silveira, 2001, p. 47).

Em 1950, pela Lei no. 1.164 (Código Eleitoral), o caráter nacional dos partidos passou a ser estipulado pela exigência da filiação de um mínimo de 50 mil eleitores, espalhados em cinco ou mais estados da federação, com pelo menos mil eleitores em cada um.

Com a intensificação da urbanização do país, a partir de meados da década de 1940, e com o fim do Estado Novo, o populismo destaca-se como uma nova

\footnotetext{
${ }^{5}$ Em 1945, o Decreto Lei $n^{\circ} 7.586$ (Lei Agamenon), de 28 de maio, introduz na legislação eleitoral brasileira a exigência de organização em bases nacionais para o registro de partidos políticos pelo TSE. O critério foi o de conceder o registro eleitoral provisório a todas as organizações partidárias que fossem apoiadas por lista de pelo menos 10 mil eleitores. Esse total deveria estar, por sua vez, distribuído em, no mínimo, cinco estados da federação, com não menos de 500 eleitores em cada um deles.
} 
característica importante da cultura política do país. Os pactos entre poder político e população definem-se com mais intensidade nas áreas urbanas.

Durante o período de 1945 a 1964, os representantes para os cargos do executivo eram escolhidos pelo sistema majoritário de maioria simples, sendo eleito apenas o candidato que obtivesse o maior número de votos. A eleição, portanto, definia-se em um único turno.

A tabela abaixo demonstra a porcentagem de votos atribuídos aos presidentes eleitos através do voto direto, neste primeiro período:

Tabela 1

Presidentes da República Eleitos - 1945-1960

\begin{tabular}{l|l|l}
\hline Presidente Eleito & Ano & \% de votos \\
\hline Eurico Gaspar Dutra & 1945 & 55,3 \\
\hline Getulio Vargas & 1950 & 48,7 \\
\hline Juscelino Kubitschek & 1955 & 35,6 \\
\hline Jânio Quadros & 1960 & 48,3 \\
\hline
\end{tabular}

Fonte: Que Brasil é Este, Wanderlei Guilherme dos Santos (Nicolau, 1999, p.28)

O sistema proporcional, implantado em 1945, utilizava a lista aberta nas eleições para a Câmara dos Deputados, Assembléia Legislativa e Câmara dos Vereadores. Através do voto preferencial, necessariamente dado a um candidato, o eleitor não contava com a possibilidade de escolher apenas uma legenda. $E$, a partir de 1950, a renovação do Senado Federal passou a ocorrer alternadamente por 1/3 e 2/3. Na Câmara dos Deputados, a renovação é integral. A duração dos mandatos dos senadores e deputados federais era de, respectivamente, oito e quatro anos. Entre 1945 a 1962, aproximadamente 12 partidos brasileiros concorreram a vagas legislativas do Congresso Nacional. 


\subsection{A instalação do meio técnico-científico sob a centralização política do território}

\section{A proporcionalidade da representação como estratégia de manutenção do controle do território}

Em 1964, com a implantação do Regime Militar, foram suspensos os direitos políticos e a representatividade das eleições. O Ato Institucional nำ1, de 9 de abril do mesmo ano, ao mesmo tempo, legitimava as Forças Armadas como o poder político do país e aumentou drasticamente as prerrogativas do poder executivo, restringindo as do Congresso Nacional. Por outro lado, mantinha a vigência do texto constitucional de 1946 e do calendário eleitoral.

O ambiente político em que se dava a votação e a apuração das eleições, no Brasil, de certa forma, era influenciado pela instabilidade democrática vivida pela sociedade brasileira durante o período. Havia, também, muitas denúncias de fraudes eleitorais. Estas, no entanto, há muito tempo estavam presentes na cultura política brasileira.

Em plena ditadura militar, é promulgado o novo Código Eleitoral, Lei nํㅡ. 4.737 de 15 de julho de 1965, que sistematização todo o sistema eleitoral a partir de então. Na mesma data é editada a LOPP, Lei n 4.740 (Lei Orgânica dos Partidos Políticos), que estabelecia critérios quantitativos maiores e mais abrangentes quanto a representatividade partidária no território nacional para a confirmação dos registros eleitorais dos partidos políticos existentes. Segundo a nova lei, "cada legenda deveria receber o apoio prévio de listas de eleitores totalizando, pelo menos, $3 \%$ do eleitorado que tivesse votado na última eleição para a Câmara dos Deputados. Esses eleitores deveriam estar distribuídos em 11 ou mais Estados, com um mínimo de $2 \%$ em cada um deles. Quanto ao desempenho eleitoral propriamente dito, a lei determinava que seriam cancelados os registros dos partidos que, mesmo cumprindo as cláusulas anteriores, não conseguiam eleger pelo menos 12 deputados federais, distribuídos em, no mínimo, sete estados da federação".

No mesmo ano de 1965, vários candidatos a governador apoiados pelo Regime Militar sofreram derrotas em Estados importantes. A seguir, o governo Militar 
extinguiu compulsoriamente todos os 13 partidos políticos em funcionamento legal no Brasil. Com o Ato Institucional $n^{\circ}$ 2, de 27 de outubro, as eleições presidenciais tornaram-se indiretas e, por decretos posteriores, foram abolidas as eleições diretas para os governos estaduais e para algumas prefeituras municipais (capitais, cidades consideradas áreas de segurança nacional e estâncias hidrominerais) também viriam a ser abolidas por decretos posteriores.

Ao longo dos anos da Ditadura Militar, muitas as alterações foram incluídas no Código Eleitoral Brasileiro, que visavam favorecer interesses do regime antidemocrático da época.

O Ato Complementar $\mathrm{n}^{\circ} \mathrm{4}$, de 20 de novembro, conferia aos membros do Congresso Nacional (deputados federais e senadores) a iniciativa de criar novas organizações com atribuições de partidos para a disputa das eleições congressuais de 1966. As novas exigências para as organizações partidárias impediam, indiretamente, o surgimento de várias agremiações, pois para se registrarem era necessário a filiação de no mínimo 120 deputados federais e 20 senadores. 0 resultado desta nova normatização foi a criação, no ano seguintes, de dois grupos parlamentares: Aliança Democrática Nacional (ARENA), da situação, e Movimento Democrático Brasileiro (MDB), composta pelos opositores do regime.

Como resultado do processo de filiação dos membros do Congresso Nacional às duas novas siglas, a Arena agrupou $62,8 \%$ dos parlamentares da Câmara do Deputados e o MDB 36,4\% (Kinzo, 1988 apud, R. Schmitt, 2000, p. 35). $\mathrm{Na}$ composição do Senado, a Arena representava 69,2\% das cadeiras, enquanto que o MDB 30,8\% (Anais do Senado).

Com a promulgação da Constituição de 1967, as exigências relativas ao caráter nacional dos partidos foram condicionadas à mais rigorosa cláusula de desempenho (a votação mínima por Estados requerida para o funcionamento de partidos no legislativo) de toda a história da legislação eleitoral no Brasil. A seguir, edita-se o Ato Institucional no 5, de 13 de dezembro de 1968, inaugurando o período mais repressivo do regime autoritário, quando se impõem um recesso compulsório ao Congresso Nacional. 
Dois anos depois, a Emenda Constitucional no 1 (de 17 de outubro de 1969) introduz na legislação eleitoral brasileira a fidelidade partidária aos detentores de mandatos legislativos e suaviza a cláusula de desempenho exigida dos partidos políticos. As duas modificações são mantidas na segunda versão da Lei Orgânica dos Partidos Políticos, Lei no 5.682, de 21 de julho de 1971.

Em meados da década de 1970, "a diminuição da atividade econômica que afetava o país como um todo parecia, então uma ameaça à continuidade do modelo. Para mantê-lo, era indispensável retomar a atividade, ao preço de investimentos públicos mais numerosos e mais injeção de recursos para promover a exportação, mais proteção ao grande capital, menor retribuição ao trabalho, ao preço de uma política social ainda menos generosa e, necessariamente, de uma ordem ainda maior no campo político-social" (M. Santos e M. L. Silveira, 2001, p. 48)

A partir de 1974, O MDB começa a aumentar sua participação no Congresso Nacional. Frente ao crescimento eleitoral da oposição, o governo militar promulga-se, em julho de1976, a Lei no 6.339 (Lei Falcão), que impunha severos limites às campanhas eleitorais no rádio e na televisão, em vigor até o pleito de 1982.

Nessa nova conjuntura, várias medidas são decretadas com o intuito de deter o avanço da oposição no Congresso. Com o propósito da manutenção do equilíbrio de forças favorável à situação, a Emenda Constitucional no 8, de 1977 criou a figura do senador biônico para as eleições de 1978 e aumentou a representação na Câmara dos Deputados dos estados das regiões Norte e Nordeste, onde a Arena tinha, comparativamente às demais regiões, um melhor desempenho eleitoral. Aqui, fica evidente a mediação das normas no uso do território. Tanto os dados do uso efetivo do território condicionam a formulação de normas, em benefício de um grupo político; como as normas, assim elaboradas, possibilitam a construção ou manutenção de um equilíbrio de forças na disputa pelo uso do território nacional promovida por instituições políticas. 


\subsection{A retomada da democracia e a recomposição da diversidade política- partidária no uso do território}

Com o aumento da pressão de setores da sociedade civil pela abertura política, entre outros fatores, começa um processo de democratização do sistema eleitoral brasileiro. No final do ano de 1979, promove-se uma Reforma Partidária, Lei no 6.767, muito significativa, que alterava vários dispositivos da lei Orgânica dos Partidos Políticos, Lei no 6.767. Uma das deliberações mais importantes foi a reinauguração da liberdade para a formação de partidos, desde que conseguissem, na legislatura seguinte para a Câmara dos Deputados, $5 \%$ dos votos nacionais e 3\% em nove estados diferentes e, por outro, tivessem entre os seus fundadores $10 \%$ dos deputados federais e $10 \%$ dos senadores. Até o final daquela legislatura, em março de 1983, qualquer número de congressistas poderia se agrupar em blocos parlamentares e requerer o registro de partido político.

Após a Reforma Partidária, surgiram seis novos partidos, todos com representantes na Câmara dos Deputados. Já a composição do Senado ficou distribuída entre 3 partidos apenas (PDS, PMDB e PP).

Em 1980, foram restabelecidas as eleições diretas para os governadores de todos os estados da federação (Emenda Constitucional no 15 , de 19 de novembro de 1980). Nas eleições de 1982, por razão da Lei no 6.978 , era obrigatório o chamado voto vinculado: o eleitor só poderia votar, sob pena de nulidade, em candidatos do mesmo partido para todos os cargos em disputa (de vereador a governador). E outra cláusula desta legislação, estipulava que, dentro de cada estado, um partido somente estaria apto a concorrer às eleições se lançasse candidatos para todos os cargos eletivos sendo disputados (de vereador a governador). Caso contrário, a legenda não poderia participar do processo eleitoral naquela unidade da federação.

No pleito de 1982, três partidos ganharam as disputas para governadores: PDS (12 candidatos eleitos), PMDB (9 candidatos eleitos) e PDT (com 1 candidato vitorioso). As mesmas agremiações conseguiram representantes no Senado e na Câmara dos Deputados, onde dividiram as vagas também com o PT e o PTB. 
No ano de 1985, marco da conquista da abertura política, realizaram-se eleições indiretas para a presidência da República ${ }^{6}$, onde o candidato do PMDB, Tancredo Neves, ganhou por uma larga margem de votos o candidato do PDS, Paulo Maluf. Depois da morte de Tancredo Neves, que não chegou a assumir o cargo, o vice-presidente eleito, José Sarney toma posse em 15/03/1985, como o primeiro presidente civil depois do Regime Militar.

No mesmo ano, a Emenda Constitucional $n^{\circ} 25$, restabeleceu as eleições presidenciais diretas e retirou da Constituição o dispositivo referente à fidelidade partidária. Ratificou-se, também, a autorização para a livre criação de novos partidos políticos e a reorganização de todas as siglas que tivessem tido os seus registros indeferidos, cancelados ou cassados durante a vigência do regime autoritário e modificou-se a cláusula de desempenho, tornando-a mais branda do que a que estava em vigor até então, para a representação dos partidos políticos nas duas casas do Congresso. O PCB, que atuava na clandestinidade desde 1947, foi legalizado.

Com Lei nำ 7.454, todos os partidos com registro provisório ou em formação puderam concorrer às eleições congressuais de 1986, que elegeram os parlamentares da Assembléia Nacional Constituinte (ANC), responsável pela formulação da nova e democrática Constituição Brasileira.

\footnotetext{
${ }^{6}$ O Colégio Eleitoral compunha-se de 686 membros: os 479 deputados federais e 69 senadores no exercício do mandato e mais 138 delegados, representando os partidos majoritários em cada Assembléia Legislativa Estadual (seis delegados por estado).
} 


\section{Capítulo 2: O período atual}

\subsection{A geografia eleitoral da globalização e novas formas de uso corporativo do território.}

Hoje, com a globalização, "o território ganha novos conteúdos e impõe novos comportamentos, graças às enormes possibilidades da produção e, sobretudo, da circulação dos insumos, dos produtos e do dinheiro, das idéias e informações, das ordens e dos homens" (M. Santos e M. L. Silveira, 2001, pp. 52$53)$.

Como duas variáveis centrais deste período, o dinheiro e a informação (M. Santos 1994b, 1996, 2000) ajudam-nos a entender os campos de forças que se delineiam e as ações e objetos que os condicionam e são por eles condicionadas.

Neste período do chamado meio técnico-científico-informacional ( $M$. Santos), fase avançada do modo de produção capitalista, as ações no território são rigorosamente programadas pelos agentes hegemônicos, contando amiúde com a colaboração fiel da ação estatal.

As normas eleitorais não fogem a esta regra. Nesse sentido perguntamonos: quais partidos serão os decididores ${ }^{7}$ da proposta de lei vencedora? Quais interesses partidários e sócio-econômicos serão os beneficiários das novas normatizações das ações eleitorais? Outra questão refere-se a uma das principais propostas da atual Reforma Política: financiamento privado ou público das campanhas eleitorais.

Uma nova normatização da prática eleitoral não significa necessariamente novas formas mais representativas das vozes dos cidadãos de uma nação, de suas regiões ou lugares, uma vez que hoje é possível a construção de uma opinião pública ao nível nacional ou mundial, ou vinculada aos interesses dos atores hegemônicos, que dominam as variáveis-chave do período, entre elas a produção da informação. Vemos que, nas últimas duas décadas, as campanhas eleitorais

\footnotetext{
${ }^{7}$ Para M. Santos (1996, p. 65), os agentes socioespaciais decididores distinguem-se dos outros. Para o autor, "um decididor é aquele que pode escolher o que vai ser difundido e, muito mais, aquele capaz de escolher a ação que, nesse sentido, se vai realizar".
} 
transformaram-se, rapidamente, em verdadeiras campanhas publicitárias, esvaziando-se de seu conteúdos políticos mais genuínos. 


\subsection{A informatização das eleições e modernização do território}

A informatização do processo eleitoral com a implantação da urna eletrônica foi avaliada por muitos como sendo uma contribuição positiva para o sistema eleitoral brasileiro por facilitar o ato de votar, sobretudo para eleitores dos lugares com menor grau de instrução, e assim estimular o exercício do direito de escolha de seus representantes. Percebemos ao longo do trabalho que o voto eletrônico pode ser entendido como uma técnica que facilita o ato de votar. Essa facilidade pode servir, talvez, ao funcionamento de um sistema democrático mais direto e participativo, baseado em referendos ou plebiscitos que expressem da vontade dos cidadãos. Todavia, um objeto técnico em si não aumenta ou diminui a consciência política das pessoas ou a cultura política de uma nação. Mas, de alguma forma, ao participar do sistema político esses objetos técnicos influenciam o processo e os seus outros elementos. Por isso, a informatização das eleições interfere na construção da atual cultura política brasileira, seja na tentativa de lisura das eleições, seja no saneamento dos títulos de eleitor.

A informatização das eleições vista, então, como parte do processo de modernização do território alterava a fluidez e o tempo de produção das informações essenciais para a geografia eleitoral do país.

Com o voto manual, os votos eram contabilizados nos locais de atuação do candidato. Dessa forma, a informação estava segura nos locais das contagens permitindo, muitas vezes, um controle ou manipulação do voto. O mapismo possibilitava a alteração de dados no momento do preenchimento dos boletins de urna. Outra forma de fraude ficou conhecida como quebra de linha. Tratava-se do lançamento de dados na linha inferior ou superior ao campo destinado ao candidato no boletim de urna, muito comum nas apurações, devido ao cansaço dos apuradores, ou a atitude fraudulenta. Com a urna eletrônica e sua rede territorial, essa etapa do processamento das informações eleitorais, localizada territorialmente, deixa de existir. Instala-se uma nova fluidez, talvez, nesse caso mais benéfica ao exercício da democracia. Quando se institui o processo da fluidez, ou seja, da rapidez do deslocamento da informação, algumas formas de manipulação das 
eleições são coibidas, já que o candidato perde a possibilidade de exercer seu poder local e não tem controle sobre a essa fluidez eleitoral, que passa a ser dos tribunais eleitorais. Da mesma forma, a produção de informações cada vez mais instantâneas é também benéfica aos atores hegemônicos que se alimentam da especulação da informação para as suas ações políticas e econômica no território. 


\subsection{A atual regulamentação do sistema político-eleitoral brasileiro e as primeiras propostas de reforma política}

Em 1988, com a Promulgação da nova Constituição, pelo artigo 17, ratificase a liberdade para a criação e extinção de partidos políticos e é resguardado o direito à autonomia destas instituições.

"Art.17. É livre a criação, fusão, incorporação e extinção dos partidos políticos, resguardados a soberania nacional, o regime democrático, o pluripartidarismo, os direitos fundamentais da pessoa humana e observados os seguintes preceitos:

I - caráter nacional;

II - proibição de recebimento de recursos financeiros de entidades ou governos estrangeiros ou de subordinação a estes;

III - prestação de contas à Justiça Eleitoral;

IV - funcionamento parlamentar de acordo com a lei.

1 - É assegurada aos partidos políticos autonomia para definir sua estrutura interna, organização e funcionamento, devendo seus estatutos estabelecer normas de fidelidade e disciplina partidárias.

2 - Os partidos políticos, após adquirirem personalidade jurídica, na forma da lei civil, registrarão seus estatutos no Tribunal Superior Eleitoral.

3 - Os partidos políticos têm direito a recurso do fundo partidário e acesso gratuito ao rádio e a televisão, na forma de lei.

4 - É vedada a utilização pelos partidos políticos de organização paramilitar”.

O Código Eleitoral Brasileiro em vigor é ainda aquele estabelecido pela Lei $n^{\circ}$. 4.737, de 1965, considerando-se, contudo as inovações que foram introduzidas ao longo das últimas quatro décadas. Destacaremos, aquelas mais recentes e que definem as atuais regras do sistema eleitoral brasileiro atual.

Quanto ao atual sistema eleitoral brasileiro, os chefes do Executivo (presidente, governadores e prefeitos) e os senadores são eleitos pelo sistema eleitoral majoritário e os ocupantes das demais cadeiras do legislativo (deputados 
federais, deputados estaduais e vereadores municipais) são eleitos pelo sistema proporcional.

A partir de 1988, por deliberação constitucional, as eleições majoritárias para presidente da república, governadores de Estado e prefeitos de municípios com mais de 200 mil eleitores passaram a ser realizadas pelo sistema de dois turnos.

A tabela abaixo demonstra os resultados das urnas em 1989, 1994 e 1998, obtidos pelos presidentes da república nas eleições, segundo as novas regras eleitorais instituídas com a constituição de 1988:

Tabela 2

Presidentes da República Eleitos - 1989-1998

\begin{tabular}{l|l|l|l}
\hline Presidente Eleito & Ano & $\begin{array}{l}\text { \% de votos primeiro } \\
\text { turno }\end{array}$ & $\begin{array}{l}\text { \% de votos segundo } \\
\text { turno }\end{array}$ \\
\hline Fernando Collor de Mello & 1989 & 30,5 & 53 \\
\hline Fernando Henrique Cardoso & 1994 & 54,3 & $-0-$ \\
\hline Fernando Henrique Cardoso & 1998 & 53,1 & $-0-$ \\
\hline
\end{tabular}

Fonte: Tribunal Superior Eleitoral

Nas eleições presidenciais de 1989, Fernando Collor de Mello obteve 30,5\% dos votos no primeiro turno, e 53\%, no segundo. Nas eleições de 1994 e de 1998 não houve segundo turno, pois o candidato Fernando Henrique Cardoso foi eleito em primeiro turno com mais de $50 \%$ dos votos válidos, respectivamente, $54,3 \%$ e $53,1 \%$ dos votos. Nas eleições de 2002 o candidato Luiz Inácio Lula da Silva foi eleito em segundo turno com $60 \%$ dos votos válidos.

Só realiza-se um segundo turno quando nenhum candidato obtém mais da metade dos votos.

A Emenda Constitucional $\mathrm{n}^{\circ}$. 16, de junho 1997, introduziu o direito à reeleição para presidente da República, governadores de estado e do Distrito Federal e prefeitos, vigorando a partir das eleições de 1998.

Quanto ao sistema proporcional, a partir de 1986, são implantadas duas inovações. Uma das novidades é que o eleitor além de continuar podendo efetuar o seu voto, escolhendo o candidato de sua preferência (voto preferencial), tem a 
opção de indicar a legenda do partido (voto de legenda). Neste último caso, o voto é contabilizado para efeito da distribuição das cadeiras, mas não é computado para nenhum dos candidatos da lista. Outra novidade do sistema de lista aberta brasileiro é "a formação de uma única lista de candidatos quando diferentes partidos estão coligados. Os candidatos mais votados, independentemente dos partidos ao qual pertençam, ocuparão as cadeiras eleitas pela coligação" (Nicolau, 1999, p. 53).

Posteriormente, a Lei 9.504/97 determina como inválidos os votos brancos, excluindo-os, assim, do quociente eleitoral usado para o cálculo da distribuição de cadeiras nas eleições proporcionais.

Quanto ao financiamento das campanhas eleitorais, a lei $n^{\circ}$. 8.713/93 introduziu o dispositivo de contribuição de pessoas jurídicas, que passaram a poder doar até $2 \%$ de seu faturamento anual ou 300 mil UFIRs, o que fosse maior.

A lei $n^{\circ}$. 9.100/95 estabeleceu uma cota, de no mínimo $25 \%$, das vagas de cada partido ou coligação a ser preenchida por candidaturas de mulheres. Isso entrou em vigor nas eleições de 1996, e, a partir das eleições de 2000, o percentual passou para $30 \%$.

A partir de 1995, a Lei Orgânica dos Partidos Políticos (LOPP), Lei nº. 9.096/95, regulamentou sobre a constituição e o funcionamento do partidos políticos. Com a LOPP, os partidos políticos tiveram confirmado o seu novo estatuto de pessoa jurídica de direito privado (e não mais de direito público).

Para J. Dirceu e lanoni (1999, p. 14), as novidades na legislação eleitoral eram "a autonomia partidária, inclusive no que se refere à fidelidade (que passa a ser um princípio constitucional a ser normatizado pelos partidos, sem, no entanto, poder chegar a cassação do mandato), e o estatuto de pessoa jurídica de direito privado, e não mais de direito público, dos partidos".

Pela LOPP, quanto à exigência de caráter nacional dos partidos políticos, o Tribunal Superior Eleitoral (TSE) somente está autorizado a conceder registro a novas organizações partidárias que sejam apoiadas por assinaturas de, no mínimo, $0,5 \%$ do eleitorado votante (exclusive votos nulos e em branco) na mais recente eleição para a Câmara dos Deputados. Esses eleitores devem estar distribuídos por 
pelo menos $1 / 3$ dos estados, e em nenhum deles podem ser em número inferior a $0,1 \%$. Por outro lado, a LOPP também estipulou que os partidos que, na data de sua promulgação, já tivessem o registro eleitoral definitivo estariam dispensados dessa exigência. 


\subsection{A cláusula de desempenho e as conseqüências territoriais para a geografia partidária brasileira}

O Artigo 13 da LOPP, re-insere na legislação partidária brasileira a polêmica cláusula de desempenho, relativo ao funcionamento parlamentar dos partidos registrados, conhecido como "cláusula de barreira" ou "cláusula de exclusão". O artigo determina que: "Art. 13 - Tem direito a funcionamento parlamentar, em todas as Casas Legislativas para as quais tenha elegido representantes, o partido que, em cada eleição para a Câmara dos Deputados, obtenha o apoio de, no mínimo, cinco por cento dos votos apurados, não computados os em branco e os nulos, distribuídos em, pelo menos, um terço dos Estados, com um mínimo de dois por cento do total de cada um deles".

Esse limiar restringe de forma drástica o número de partidos com possibilidades de funcionamento parlamentar. Nas eleições de 3 de outubro 1998, na qual 30 partidos políticos concorreram com candidaturas para a Câmara dos Deputados, apenas 7 deles alcançaram os índices estabelecidos. 
Tabela 3

Resultado Eleitoral de 1998 - Eleição para a Câmara dos Deputados Federais

\begin{tabular}{|c|c|c|c|c|}
\hline Partido & votação & $\begin{array}{l}\% \text { dos votos } \\
\text { válidos apurados }\end{array}$ & $\begin{array}{l}\mathrm{n}^{\circ} \text { de UF(s) em que obteve mais de } \\
2 \% \text { dos votos válidos apurados }\end{array}$ & $\begin{array}{c}n^{\circ} \text { de deputados } \\
\text { eleitos }\end{array}$ \\
\hline PAN & 62.651 & 0,09 & 0 & - \\
\hline PC do B & 869.292 & 1,31 & 4 & 7 \\
\hline PCB & 49.619 & 0,7 & 0 & - \\
\hline $\mathrm{PCO}$ & 8.067 & 0,01 & 0 & - \\
\hline PDT & 3.774 .511 & 5,67 & 18 & 25 \\
\hline PFL & 11.525 .279 & 17,31 & 27 & 105 \\
\hline PGT & 27.825 & 0,04 & 0 & - \\
\hline$P L$ & 1.643 .941 & 2,47 & 13 & 12 \\
\hline PMDB & 10.105 .896 & 15,17 & 26 & 83 \\
\hline PMN & 360.214 & 0,54 & 2 & 2 \\
\hline PPB & 7.553 .169 & 11,34 & 26 & 60 \\
\hline PPS & 872.220 & 1,31 & 4 & 3 \\
\hline PRN & 54.285 & 0,08 & 0 & - \\
\hline PRONA & 592.634 & 0,89 & 1 & 1 \\
\hline PRP & 255.516 & 0,38 & 0 & - \\
\hline PRTB & 53.785 & 0,08 & 0 & - \\
\hline PSB & 2.273.219 & 3,41 & 11 & 18 \\
\hline PSC & 446.329 & 0,67 & 2 & 2 \\
\hline PSD & 503.725 & 0,76 & 0 & 3 \\
\hline PSDB & 11.681 .956 & 17,54 & 27 & 99 \\
\hline PSDC & 62.055 & 0,09 & 0 & - \\
\hline PSL & 177.035 & 0,27 & 2 & 1 \\
\hline PSN & 136.834 & 0,21 & 0 & - \\
\hline PST & 193.562 & 0,29 & 0 & 1 \\
\hline PSTU & 187.683 & 0,28 & 0 & - \\
\hline PT & 8.786 .528 & 13,19 & 27 & 59 \\
\hline PT do B & 216.645 & 0,33 & 1 & - \\
\hline PTB & 3.768 .196 & 5,66 & 17 & 31 \\
\hline PTN & 64.712 & 0,10 & 0 & - \\
\hline PV & 292.694 & 0,44 & 0 & 1 \\
\hline Total & 66.600 .077 & 100,00 & - & 513 \\
\hline
\end{tabular}

Fonte: Banco de Dados do Tribunal Superior Eleitoral, 1998

$\square$ Partidos que atingiram, individualmente, os requisitos do art. $13^{\circ}$ da Lei 9096/95 
Todavia, essa "cláusula de barreira", segundo o Artigo 57 da LOPP, só entrará em vigor a partir das eleições de 2006, após um período de transição de 11 anos. Até lá os critérios poderão mais flexíveis. $\mathrm{O}$ acesso à Câmara dos Deputados até 2006 estará garantido a partidos com registro definitivo que não satisfaçam a cláusula de desempenho, desde que 1) tenham eleito (ou venham a eleger) qualquer número de deputados federais em duas eleições consecutivas ou 2) tenham eleito (ou venham a eleger), numa única eleição, deputados federais em no mínimo cinco estados e também obtido (ou venham a obter) pelo menos $1 \%$ da votação nacional (exclusive votos em branco e nulos). 
Tabela 4

Resultado Eleitoral de 2002 - Eleição para a Câmara dos Deputados Federais

\begin{tabular}{|c|c|c|c|c|}
\hline Partido & votação & $\begin{array}{c}\% \text { dos votos } \\
\text { válidos apurados }\end{array}$ & $\begin{array}{c}\mathrm{n}^{\circ} \text { de UF(s) em que obteve mais } \\
\text { de } 2 \% \text { dos votos válidos } \\
\text { apurados }\end{array}$ & $\begin{array}{c}\mathrm{n}^{\circ} \text { de deputados } \\
\text { eleitos }\end{array}$ \\
\hline PAN & 126.666 & 0,14 & 0 & 0 \\
\hline$P C$ do $B$ & 1.967 .847 & 2,25 & 10 & 12 \\
\hline PCB & 45.963 & 0,05 & 0 & 0 \\
\hline $\mathrm{PCO}$ & 29.351 & 0,03 & 0 & 0 \\
\hline PDT & 4.482 .538 & 5,12 & 18 & 21 \\
\hline PFL & 11.706 .253 & 13,38 & 26 & 84 \\
\hline PGT & 194.686 & 0,22 & 1 & 0 \\
\hline PHS & 294.928 & 0,34 & 0 & 0 \\
\hline PL & 3.780 .930 & 4,32 & 20 & 26 \\
\hline PMDB & 11.691 .526 & 13,37 & 26 & 76 \\
\hline PMN & 282.878 & 0,32 & 3 & 1 \\
\hline PPB & 6.828 .375 & 7,81 & 26 & 48 \\
\hline PPS & 2.682 .487 & 3,07 & 14 & 15 \\
\hline PRONA & 1.804 .655 & 2,06 & 2 & 6 \\
\hline PRP & 251.971 & 0,29 & 0 & 0 \\
\hline PRTB & 304.092 & 0,35 & 1 & 0 \\
\hline PSB & 4.616 .674 & 5,28 & 14 & 22 \\
\hline PSC & 504.611 & 0,58 & 4 & 1 \\
\hline PSD & 452.386 & 0,52 & 4 & 4 \\
\hline PSDB & 12.473 .743 & 14,26 & 23 & 70 \\
\hline PSDC & 192.546 & 0,22 & 1 & 1 \\
\hline PSL & 408.512 & 0,47 & 3 & 1 \\
\hline PST & 504.044 & 0,58 & 2 & 3 \\
\hline PSTU & 159.251 & 0,18 & 0 & 0 \\
\hline PT & 16.094 .080 & 18,40 & 25 & 91 \\
\hline PT do B & 168.639 & 0,19 & 1 & 0 \\
\hline PTB & 4.052 .111 & 4,63 & 19 & 26 \\
\hline PTC & 74.955 & 0,09 & 0 & 0 \\
\hline PTN & 118.471 & 0,13 & 0 & 0 \\
\hline PV & 1.179 .374 & 1,35 & 3 & 5 \\
\hline Total & 87.474.543 & 100 & - & 513 \\
\hline
\end{tabular}

Fonte: Banco de Dados do Tribunal Superior Eleitoral, 2002

Partidos que atingiram, individualmente, os requisitos do art. $13^{\circ}$ da Lei 9096/95 
A LOPP também regulamenta sobre os critérios para o acesso dos partidos a três recursos fundamentais: o funcionamento parlamentar, o programa gratuito de rádio e televisão e o fundo partidário. $O$ acesso aos dois últimos recursos somente é garantido se os partidos preencherem as exigências para o acesso ao primeiro.

Desde o pleito municipal de 1985 até o municipal de 1996, o Congresso Nacional aprovava uma legislação específica regulamentando a eleição vindoura. A Lei $\mathrm{n}^{0}$ 9.504, de 30 de setembro de 1997, pretendeu extinguir esta prática, determinando normas gerais para todo o calendário eleitoral brasileiro ${ }^{8}$. Está sendo aplicada desde as eleições gerais de 1998. Ela delibera, também, sobre a propaganda eleitoral, o voto eletrônico, as pesquisas pré-eleitorais e o financiamento das campanhas.

\footnotetext{
${ }^{8}$ O calendário eleitoral brasileiro está, desde 1994, estruturado de forma a haver permanente coincidência do pleito presidencial com os pleitos estaduais (governadores, senador, deputado federal e deputado estadual). Os mandatos presidenciais, dos governadores e dos deputados federais são todos de quatro anos, renovados simultaneamente. O mandato dos senadores continua sendo de oito anos, mas a sua renovação é sempre simultânea à dos demais cargos (alternadamente por 1/3 e 2/3). Somente a eleição presidencial de $1989-a$ primeira em quase 30 anos - foi "solteira", isto é, isolada de qualquer outra. Essas eleições se realizam, coincidentemente, nos anos de Copa do Mundo. As eleições municipais (prefeitos e vereadores), que completam o calendário eleitoral, irão acontecer nos anos em que também são promovidas as Olimpíadas. Não há mais eleições para vice-presidente e vice-governador; os candidatos a tais cargos são registrados pelos partidos conjuntamente com os respectivos titulares, e a eleição destes implica na do seu companheiro de chapa (R. Schmit, 2000).
} 


\section{Capítulo 3: Reforma política e uso do território}

Qualquer norma traz em sua constituição uma ação programada ${ }^{9}$ (N. Bobbio, 2001, p. 26), ou seja, uma intencionalidade. Para M. L. Silveira (2003) a norma é, de um lado, a ação cristalizada, uma forma de trabalho morto. De outro, ela prescreve, modeliza novas ações. As diferentes intencionalidades fazem com que estas regras sejam "muito diversas pelas finalidades que perseguem, pelo conteúdo, pelo tipo de obrigação que fazem surgir, pelo âmbito de suas validades, pelos sujeitos a quem se dirigem. Mas todas têm em comum um elemento característico que consiste, como veremos melhor em seguida, em ser proposições que tem a finalidade de influenciar o comportamento dos indivíduos e dos grupos, de dirigir as ações dos indivíduos e dos grupos rumo a certos objetivos ao invés de rumo a outros". A norma, originariamente uma ação programada, tem por objetivo conduzir as ações porvir, ou seja, estabelece um padrão desejável de ação.

Neste período do chamado meio técnico-científico-informacional, fase avançada do modo de produção capitalista, as ações no território são rigorosamente programadas pelos agentes hegemônicos. "Em tais condições, no período atual, a 'organização' das 'coisas' passa a ser um dado fundamental. Daí a necessidade de adoção, de um lado, de objetos susceptíveis de participar dessa ordem e, de outro lado, de regras de ação e de comportamento a que se subordinem todos os domínios da ação instrumental. Segundo M. Godelier (1972) 'objetos não relacionados constituem uma realidade desprovida de existência', enquanto a vida social se organiza em derredor de "princípios explícitos" [...] 'normas criadas intencionalmente'. Num mundo globalizado, isso supõem, para entender o espaço, a necessidade de ir além da função localmente exercida e de também considerar suas motivações, que podem ser distantes e ter até mesmo um fundamento planetário" (M. Santos, 1996, p.182).

\footnotetext{
${ }^{9}$ Para H. Kelsen (1998, 1960, p. 5), entre outros autores, "com o termo 'norma' se quer significar que algo deve ser ou acontecer, especialmente que um homem se deve conduzir de determinada maneira". Em outras palavras N. Bobbio (2001, p. 26) fala da norma como ação programada. Para ele, "cada indivíduo, ademais, separado da sociedade a que pertence, formula para a direção da própria vida programas individuais de ação: também estes programas são conjuntos de regras. Cada grupo humano, cada indivíduo singular, enquanto estipula objetivos a atingir, estipula também os meios mais adequados, ou aquele que julga mais adequados para atingi-los".
} 
Quando abordamos as normas a partir da constituição do espaço e seu dinamismo, vemos que as normas são um dado da política no uso do território. Daí, o alerta de M. Santos (1996) sobre a questão da confusão atual quanto o caráter técnico das normas. De fato, qualquer norma - seja ela de origem pública ou privada; interna ou externa às empresas; de ordem técnica ou não ${ }^{10}$ - contém um conteúdo político, beneficiando este ou aquele uso, este ou aquele agente socioespacial.

Temos, desse modo, as normas como prescrição ou como ação programada atendendo a objetivos diversos e conflitantes, revelando, juntamente com outros fenômenos, o território usado como um campo de forças. O debate em torno da necessidade da criação de novas normas eleitorais explicita esse conflito de interesses, gerado por objetivos e finalidades nem sempre coincidentes, já evidente, por exemplo, na questão da cláusula de barreira apresentada anteriormente.

\subsection{Algumas propostas e suas intencionalidades}

A "reforma política" refere-se a uma temática bem específica relativa à forma que devem ter os mecanismos institucionais - em particular, os mecanismos eleitorais e partidários - para a constituição de um regime político representativo adequado às condições atuais do país.

No Brasil, o debate da Reforma Política teve diferentes períodos desde 1988. "Um primeiro período de discussões desembocou na Constituição de 1988, que criou o arcabouço geral das instituições de representação política hoje vigente no Brasil. No entanto, as discussões continuaram por vários motivos e caminhos. Primeiro, porque o adiamento da decisão sobre o sistema de governo (parlamentarista ou presidencialista) criou uma situação de incerteza até o plebiscito de 1993, que decidiu pelo presidencialismo. Segundo, porque a legislação eleitoral e

\footnotetext{
10 Hoje, as normas das empresas "tanto podem ser internas, relativas ao seu funcionamento técnico, como externas, relativas ao seu comportamento político, nas suas relações com o poder público e nas suas relações, regulares ou não, com outras firmas, sejam essas relações de cooperação ou de concorrência [...]. As normas ditas internas atingem o entorno da empresa, já que suas pausas e seus horários de funcionamento, seus custos e preços, seus impostos e suas isenções atingem, direta ou indiretamente, o universo social e geográfico em que estão inseridas ativamente" (M. Santos, 1996, p.183).
} 
partidária infraconstitucional necessitava de adaptações para ajustá-la à nova Constituição e à nova realidade do país. Terceiro, porque as decisões dos constituintes foram postas em causa por grupos relativamente grandes de estudiosos e políticos, em especial a decisão de manter o sistema eleitoral proporcional" (M. N. Rabat, 2002, p. 3).

Essa conjuntura resultou na instalação de várias Comissões no Congresso Nacional - e, em particular, na Câmara dos Deputados - para o estudo de temas específicos relativos à "reforma política" ou para o estudo global da temática nela envolvida. Verificou-se, ao longo do tempo, uma preocupação central nas discussões: "a de criar condições para o surgimento e consolidação de um sistema de partidos estável, representativo das clivagens sociais mais importantes e eficaz na formação de governos" (M. N. Rabat, 2002, p. 3). Tal preocupação refletia uma avaliação bastante recorrente de que o funcionamento sistema partidário brasileiro apresentava problemas estruturais.

Com resultado deste processo, a Comissão Especial de Reforma Política elaborou o Projeto de Lei $n^{\circ}$ 2.679/2003, que tramita apenso ao PL n 5.268/2001 ${ }^{11}$. Tal projeto já foi objeto de Parecer do Deputado Rubens Otoni, pela constitucionalidade, juridicidade e técnica legislativa e, no mérito, pela aprovação, no âmbito da Comissão de Constituição e Justiça e de Cidadania da Casa, no final de 2004.

O PL $n^{\circ} 2.679 / 2003$, conquanto restrito ao plano das leis ordinárias, implica modificações significativas para o funcionamento de nosso sistema eleitoral e partidário, fundamentando-se em algumas propostas de caráter estrutural: 1. adoção de listas pré-ordenadas e financiamento público de campanha

Em nossa pesquisa estamos optando por enfocar, dentro de vasto temário da Reforma Política, estas duas proposições de alteração do sistema político

\footnotetext{
11 "A razão da apensação do PL n 2.679/2003, que resultou dos trabalhos da Comissão Especial de Reforma Política, ao longo do ano de 2003, ao PL $n^{\circ} 5.268 / 01$, foi a de encontrar-se este último em tramitação desde a $51^{\text {a }}$ legislatura, tendo sido elaborado pela Comissão Especial Destinada ao Estudo das Reformas Políticas, que nela funcionou, e contendo, também, propostas de alteração da legislação político-eleitoral. Suas propostas visam, todavia, a modificações menores nas normas atuais, sendo seu escopo o de facilitar e dar transparência às eleições e ao trabalho da Justiça Eleitoral" (M. N. Rabat, 2002).
} 
brasileiro. A razão de nossa opção fundamenta-se no fato de que as duas propostas contribuem para evidenciar como o sistema político eleitoral participa do atual uso do território brasileiro, com ênfase ação das instituições partidárias, e quais as possibilidades de novos usos estão sendo delineadas.

A proposta de adoção das listas pré-ordenadas revela uma tentativa explícita de fortalecer o papel dos partidos políticos em detrimento da escolha direta do eleitor no candidato. Objetiva ter partidos políticos "mais sólidos", ou seja, que as escolhas partidárias sejam as mediadoras das escolhas eleitorais, significando alterações no jogo político no sentido de conferir maior poder sobretudo às elites partidárias.

A discussão sobre o financiamento público ou privado das campanhas eleitorais, tanto no Brasil como em outras democracias, fundamenta-se em argumento comum: tentar evitar ou minimizar a interferência do poder da empresas, que propositadamente investem grandes montas de dinheiro no financiamento de candidatos, atrelando-os futuramente à política das empresas, tornando o jogo político desigualmente favorável a setores hegemônicos do poder econômico. Este tema mostra claramente a relação indissociável entre os sistemas de objetos e de ações no território. Além disso, desvela como o fazer político, no período atual, é comandado pelas variáveis determinantes da globalização: o dinheiro e a informação (M. Santos, 2000). 


\subsection{Territorialização do voto e a questão das listas pré-ordenadas}

O projeto de lei $n^{\circ} .2679$, e o Substitutivo Otoni propõe a extinção da atual sistemática de voto atualmente em vigor no sistema eleitoral brasileiro: o voto nominal com sistema proporcional, também conhecido como "lista aberta". Nesta sistemática há uma lista, mas é oferecido ao eleitor a possibilidade de escolher, um dos candidatos, sem obrigação de obedecer a qualquer ordem previamente estipulada na lista apresentada pelo partido.

J. N. Nicolau (1999, p. ) faz os seguintes comentários sobre o sistema de lista aberta: "Na lista aberta os partidos têm fortes incentivos para atrair nomes de lideranças e personalidades com 'alta popularidade'. Como a bancada final de um partido depende do somatório dos votos que cada candidato conquista individualmente, quanto mais nomes expressivos o partido tiver, maiores as chances de eleger uma bancada significativa. Por outro lado, o partido tem mecanismos limitados para favorecer a eleição de lideranças partidárias incapazes de conquistar tantos votos quanto outros nomes com forte apelo eleitoral".

Segundo o Projeto de Lei a proposta é a de adoção de lista pré-ordenada dos partidos ou das federações partidárias, também conhecido como "lista fechada" elaborada por votação secreta dos convencionais (filiados que participam das convenções partidárias deliberativas), em cada circunscrição. Votam os convencionais nos candidatos e a lista é ordenada respeitando-se sua votação. Cada convencional pode votar em até três nomes, mas poderá, também, usar todos os três votos para um só candidato, ou dar dois votos a um candidato e o terceiro a um outro (A. O. Cintra, 2005).

Já no Substitutivo, "a lista partidária ou federativa resulta da competição de chapas na convenção. Computados os votos de cada chapa, a distribuição dos lugares na lista final será obtida em sucessivas rodadas, ganhando a vaga em disputa em cada rodada a chapa que apresentar a maior média de votos por lugar. Trata-se do método já usado em nosso Código Eleitoral para a distribuição das 
vagas que sobraram após o uso dos quocientes eleitorais (Lei n 4.737/1965, art. 109)" (A. O. Cintra, 2005).

Vários são os países que adotam o sistema do voto em lista fechada. Para seus defensores, tal sistema tem como principal vantagem promover o voto partidário e, consequentemente, o fortalecimento dos partidos políticos. Por isso, tal método contribuiria para reforçar a identidade partidária.

A. O. Cintra (2005, pp. 17-18) apresenta um quadro com os principais argumentos favoráveis e contrários ao voto em lista pré-ordenada. O autor consegue agrupar argumentos de diferentes autores que versam sobre o tema, também consultados por nós.

\begin{tabular}{|c|c|c|}
\hline & Argumentos favoráveis & Argumentos contrários \\
\hline $\begin{array}{l}\text { voto em lista } \\
\text { preordenada }\end{array}$ & $\begin{array}{l}\text { 1. A escolha eleitoral passa a ser por partido. Não } \\
\text { se elimina, porém, a escolha entre líderes, pois } \\
\text { estes encabeçam as listas. } \\
\text { 2. A disputa política passa a orientar-se, mais, por } \\
\text { diferenças entre propostas partidárias com relação } \\
\text { aos vários temas do debate público, e menos por } \\
\text { pleitos clientelistas, ou seja, pelo voto no } \\
\text { candidato porque este presta favores particulares, } \\
\text { qualquer que seja a sua posição política sobre os } \\
\text { temas que serão objeto de decisão. Na lista } \\
\text { aberta, há poder sem responsabilidade, "a marca } \\
\text { do individualismo narcisista moderno que tomou } \\
\text { conta da política" (Paulo Delgado, Valor). } \\
\text { 3. A lista preordenada tem como subproduto a } \\
\text { disciplina partidária e a fidelidade, na medida em } \\
\text { que a eleição do parlamentar torna-se dependente } \\
\text { do partido, via posição dele na lista partidária. }\end{array}$ & $\begin{array}{l}\text { 1. O voto em lista quebra uma tradição acional, } \\
\text { que é, desde a implantação do sistema } \\
\text { proporcional entre nós, a do voto pessoal. Está-se } \\
\text { retirando do eleitor o direito de escolher a pessoa, } \\
\text { obrigando-a a votar numa organização burocrática } \\
\text { e impessoal, simbolizada numa lista partidária } \\
\text { fechada. Há quem argumente que se está ferindo } \\
\text { a cláusula pétrea do voto direto, substituindo-o } \\
\text { pelo voto em lista. } \\
\text { 2. É importante ter representantes com vínculos } \\
\text { com seus eleitores. O voto pessoal é mais } \\
\text { propício a fortificar esses vínculos. } \\
\text { 3. O voto em lista reforçará as oligarquias } \\
\text { partidárias, subjugando lideranças inovadoras ao } \\
\text { arbítrio dos caciques. Novas vocações políticas } \\
\text { serão desestimuladas. }\end{array}$ \\
\hline
\end{tabular}




\begin{tabular}{|c|c|c|}
\hline & Argumentos favoráveis & Argumentos contrários \\
\hline $\begin{array}{l}\text { voto em lista } \\
\text { preordenada }\end{array}$ & $\begin{array}{l}\text { 4. As trocas maciças de partido deixarão de } \\
\text { ocorrer. } \\
\text { 5. O processo político adquire maior clareza e } \\
\text { segurança, pois são organizações estáveis e não } \\
\text { arranjos episódicos, ad hoc, que conduzem as } \\
\text { negociações e acordos. } \\
\text { 6. Como conseqüência dos pontos anteriores, o } \\
\text { relacionamento entre os poderes muda de caráter, } \\
\text { pois passa a conduzir-se num outro patamar. A } \\
\text { cooptação maciça de parlamentares pelo governo } \\
\text { perderá terreno, forçando-se negociação mais } \\
\text { institucional para a tomada de decisões. } \\
\text { 7. O fazimento das listas forçará os partidos a } \\
\text { discutirem, internamente, a democracia de } \\
\text { procedimentos. Em vez da solução fácil de agora } \\
\text { - "os incomodados que se retirem" - haverá } \\
\text { debate interno, questionamentos e contestações } \\
\text { de métodos. } \\
\text { 8. Finalmente, observe-se que a sistemática } \\
\text { brasileira do voto em lista aberta, com escolha de } \\
\text { candidato, burla o eleitor, ao transferir seu voto } \\
\text { para outros, quando sua votação supera o } \\
\text { quociente eleitoral. Esses outros podem, até } \\
\text { mesmo, ser de outro partido, por força das } \\
\text { coligações. }\end{array}$ & $\begin{array}{l}\text { 4. O atual sistema não inibe as votações } \\
\text { disciplinadas em plenário, conforme tem sido } \\
\text { demonstrado pelas pesquisas da ciência política. } \\
\text { A proposta do voto em lista fechada parte de visão } \\
\text { equivocada e eivada de preconceito sobre como } \\
\text { funcionam os partidos no Congresso } \\
\text { 5. As convenções tornar-se-ão palco de disputas } \\
\text { ferozes, pois em vez de deixar o eleitor decidir } \\
\text { quem é primeiro, quem é segundo, e assim por } \\
\text { diante, conforme o número de votos, o sistema de } \\
\text { lista fechada vai passar essa função à convenção } \\
\text { partidária. } \\
\text { 6. O sistema de lista fechada pura, conforme } \\
\text { proposto, é praticado em número ínfimo de } \\
\text { países, o que sugere ser um sistema } \\
\text { problemático, que não se deve adotar por puro } \\
\text { mimetismo. }\end{array}$ \\
\hline
\end{tabular}

No âmbito da discussão da reforma partidária, o projeto em tramitação na Câmara incorporou ações afirmativas visando ampliar a presença de mulheres na política, ao propor duas medidas importantes: a destinação de pelo menos $20 \%$ do tempo de propaganda partidária gratuita na mídia para promover a participação política das mulheres e a destinação de percentual equivalente a $6 \%$ do fundo partidário para promover a formação e a participação política das mulheres. Esses dispositivos significam a regulamentação da utilização de recursos públicos e não devem ser compreendidos como interferência na autonomia partidária (A. Rodrigues, 2004, p. 6). Contudo, se adotado o novo sistema, a elaboração das listas pelos partidos terá que enfrentar o problema da baixa presença das mulheres na esfera da representação política.

O projeto conserva o dispositivo de constituição de lista fechada com o mínimo de $30 \%$ e o máximo de $70 \%$ das vagas para ambos os sexos, como já ocorre para a constituição da lista aberta. Nesse ponto, no entanto, é necessário 
observar que na lista fechada, o sistema de cotas por gênero só será eficaz caso seja garantido o lugar de mulheres e de homens na ordenação da lista, impedindo que as mulheres sejam colocadas ao final da lista e não consigam eleger-se. Dois exemplos de garantias de iguais oportunidades são marcantes pela sua eficácia. $\mathrm{Na}$ Argentina, primeiro país a adotar as cotas em lei eleitoral, em 1991, a elaboração das listas fechadas não deve apresentar mais do que dois nomes consecutivos do mesmo sexo. Segundo A. Rodrigues (2004, p. 6), nesse país as mulheres já representam 30\% do Parlamento. Nas eleições municipais francesas de 2001, houve alternância eqüitativa entre homens e mulheres na formação da lista, alcançando, dessa forma, praticamente uma proporção meio a meio na representação política nessa esfera.

A lista pré-ordenada pode também apresentar um agravamento do problema de distorções representativas dos lugares, como o favorecimento de candidatos de uma região em detrimento de outras, pois a decisão dos primeiros da lista não será mais dos eleitores, ou seja, do território usado a partir dos lugares. Se as bases das lideranças de um partido estão localizadas mais nas capitais ou numa região do estado, candidatos regionais mais distanciados do centro do poder dos partidos podem se localizar no final das listas, acentuando-se sub-representações de uma área para a outra. O fazer político, já tão desvirtuado dos seus verdadeiros propósitos, pode se afastar dos lugares e se concentrar ainda mais na arena endógena de cada partido.

Para Milnor (1969, p.197, citado por N. Bobbio, 1983 pp.1178-1179), a “... ação dos sistemas eleitorais deve ser examinada dinamicamente, partindo do pressuposto de que eles não são senão parte de um mais amplo sistema político, no âmbito do qual interagem com outras variáveis não menos importantes como são, por exemplo, as instituições constitucionais, o sistema partidário e a cultura política em geral". Considerando o papel dos sistemas eleitorais no uso do território, a introdução da lista fechada contribuirá para o fortalecimento do sistema eleitoral, conferindo-Ihe mais legitimidade e aceitação? A resposta que se apresenta registra que não há garantias de que essa modificação implicará o melhoramento do osso sistema eleitoral. 
Para vários autores, a adoção das listas fechadas é um instrumento poderoso para a consolidação do combalido sistema partidário e para a despersonificação do processo político. Contudo, esse processo só será positivo até o momento em que as elites partidárias não concentrem mais poder do que o eleitor. O estabelecimento de "ditaduras partidárias" significaria o monopólio das listas de candidatos e a perda de sua legitimidade (L. Barreto, 2003).

Para A. O. Cintra (2005), "se são necessários partidos mais sólidos, que dêem previsibilidade ao jogo político, então as listas preordenadas são recomendáveis. Se outras qualidades são privilegiadas, tais como o estabelecimento de vínculos mais densos entre representantes e representados, então se recomenda o voto nominal". Contudo, neste caso, o autor defende que é preciso que se adote o voto distrital em substituição a escala da circunscrição estadual, praticada atualmente.

\subsection{Voto distrital, só o enunciado é territorial?}

O voto distrital não foi incluído no Projeto de Lei $n^{\circ} 2.679$, elaborado pela Comissão Especial de Reforma Política, todavia aparece em várias propostas em tramitação no Congresso Nacional.

Na constituinte de 1987-88, o voto distrital misto foi derrotado, mas é crescente no Brasil adeptos a ele.

No relatório do Senador Sergio Machado propõem a adoção do voto distrital, ou sistema eleitoral misto. A combinação entre sistema majoritário e sistema proporcional foi denominada no Brasil como sistema distrital misto. Neste sistema o eleitor daria dois votos desvinculados para a escolha de deputados federais: um para o candidato de seu distrito eleitoral e outro para o partido de sua preferência. Para o primeiro voto, baseado no sistema de maioria simples, os estados seriam divididos em distritos eleitorais em cada qual apenas um candidato, o mais votado, seria eleito. O eleitor também daria um segundo voto, escolhendo uma legenda partidária á qual estaria vinculada uma lista fechada de candidatos previamente ordenada por cada partido. Metade dos representantes de cada estado seria eleita 
nos distritos e o restante pelas listas partidárias através do voto na legenda. No caso do estado de São Paulo, por exemplo, que tem 70 representantes na Câmara dos Deputados, 35 seriam eleitos nos distritos pelo sistema majoritário e o restante pelo sistema proporcional de lista fechada.

De um lado, os sistemas mistos são criticados pela complexidade que introduzem no processo eleitoral. O detalhamento necessário a sua operacionalização, pode dificultar difícil compreensão dos eleitores sobre o seu funcionamento. Outro conjunto de crítica refere-se a criação de dois tipos de candidatura, uma direta com os leitores e outra mediada pelo partido. Estimularia-se, desse modo, o estabelecimento de conexões eleitorais diferenciadas: "o deputado eleito pela parte majoritária tem fortes incentivos para cultivar laços territoriais com o seu distrito; já os parlamentares eleitos pela lista terão maiores incentivos para fortalecer a sua posição dentro do partido" (J. M. Nicolau, 1999, p.68).

Por outro lado, a preocupação com a vinculação do representante às áreas geográficas correspondentes nas reformas eleitorais em sistemas proporcionais, apontado por J. Nicolau (2003, pp. 212-213), parece-nos pertinente ao enfoque geográfico quanto à reforma política em andamento no Brasil. Segundo este autor, "a conexão entre os deputados e o eleitorado depende de vários fatores: tipo de organização partidária, possibilidade de o parlamentar alocar recursos orçamentários para sua circunscrição eleitoral, cultura política. Mas o sistema eleitoral é fator determinante. Quando apenas um parlamentar é eleito por distrito há garantia de que todo o território terá um representante no legislativo. Neste caso são fortes os incentivos para que o deputado crie vínculos mais diretos com os eleitores. No outro extremo, nos países que utilizam o sistema de lista fechada, são reduzidos os incentivos para que o representante cultive uma relação mais direta com os seus representados. Os sistemas de lista flexível e aberta estimulam uma maior personalização do voto, mas não garantem que todas as áreas geográficas tenham representantes no Parlamento. Um dos argumentos recorrentes dos defensores dos sistemas mistos (seja na sua versão de combinação, seja na de correção) é o de que a criação de um distrito que elege um único deputado teria duas vantagens: 
garantir que todas as áreas de um país tenha representantes e estimular maiores vinculações entre os parlamentares e os eleitores"

No caso brasileiro, uma reforma eleitoral, segundo o autor, deveria considerar que "o fato de algumas circunscrições conseguirem eleger um parlamentar é absolutamente contingente no sistema de lista aberta utilizado no Brasil: determinadas áreas conseguem eleger seus representantes (políticos que tem como base eleitoral o seu domicílio e outros municípios adjacentes) e outras não; algumas conseguem mais de um parlamentar, enquanto outras são incapazes de fazê-lo. Certos municípios mais populosos apresentam muitos candidatos, mas a dispersão de votos entre eles faz com que nenhum se eleja. De outro lado, alguns municípios menores que apresentam um único candidato acabam elegendo-o. Estas desigualdades têm sido avo de críticas permanentes".

Todavia, o que de fato aconteceria com o uso do território brasileiro, pelo voto, se este sistema fosse incluído? Teremos uma mudança da natureza da política, pela fragmentação do "território político"? O enunciado é territorial, pois distrital, porém qual o significado geográfico disto?

Delimitar distritos também pode garantir apenas um vínculo formal com a área geográfica? Como garantir uma vinculação geográfica que não se baseia apenas em formas (muitas vezes os casos de delimitações político-administrativas) mas sim em formas-conteúdo, no território e seu uso?

A diminuição da representatividade ( $n^{\circ}$ de representantes) das regiões que não são modernas, localizadas fora da região concentrada, leva-nos a se pensar: a diminuição da quantidade de representantes dessas regiões no poder legislativo não teria reflexo sobre a presença maior ou menos da ação estatal em áreas mais carentes de uma materialidade para o bem-estar das populações?

Seria importante pensar se a mudança na representatividade pode favorecer ou não uma política redistributiva. "Uma política efetiva redistributiva visando a que as pessoas não sejam discriminadas em função do lugar onde vivem, não pode, pois, prescindir do componente territorial” (M. Santos, 1987, p. 113). 


\subsection{Financiamento público de campanha: uma tentativa de minimizar os usos corporativos do território}

Hoje, o financiamento privado é alvo de duras críticas, não apenas pelos altíssimos custos das campanhas mas também pelas formas de arrecadação de recursos. Os custos astronômicos de campanhas políticas, mas também os financiamentos ilegais, significam condições desiguais entre os competidores e o risco de uma representação política subjugada aos interesses econômicos, lícitos ou ilícitos.

Com o financiamento privado, antes mesmo de um partido ou de um candidato se tornar governo, seu projeto territorial já está comprometido, na maioria das vezes, com um conjunto de interesses privados e, conseqüentemente, um uso corporativo do território. Todavia, esta submissão da política do Estado às políticas das empresas é, também, uma característica do período atual. O financiamento privado contribui para essa submissão de decisões políticas estatais a interesses econômicos hegemônicos, todavia não é o único elemento explicativo dessa realidade atual.

$\mathrm{Na}$ análise do papel histórico e da significação do Estado sob a ótica marxista, Lenin (1987, 1917, p. 9) reafirma que ele "é o produto e a manifestação do antagonismo inconciliável das classes. O Estado aparece onde e na medida em que os antagonismos de classes não podem objetivamente ser conciliados. E, reciprocamente, a existência do Estado prova que as contradições de classes são inconciliáveis"

O Estado aparece, desde seu nascimento, como um produto da sociedade dividida em classes, como uma necessidade frente aos interesses econômicos contrários resultantes desta divisão.

Ao analisar o Estado na perspectiva do materialismo dialético como produto das relações sociais, J. Lojikine $(1997,1977$, p. 106) faz uma crítica às teorias marxistas por fazerem uma leitura externa do aparelho de Estado. "O Estado intervém 'na periferia' da relação capital/trabalho, 'fora' da empresa como lugar de 
extorsão da mais-valia, para 'regulamentar' no nível nacional, no nível do conjunto da formação social, a reprodução dessa extorsão".

O autor defende uma outra abordagem do aparelho estatal, que considera de "dentro". Nela o Estado deve ser visto como um organismo interno às relações de produção. Deve ser entendido "como um dos momentos, uma das manifestações da contradição fundamental entre a socialização do processo de trabalho e da apropriação privada dos meios de produção e do produto do trabalho" (J. Lojikine, 1997, 1977, p. 107).

Nesse sentido, coloca ainda que "a intervenção do Estado aparece por sua vez como forma mais desenvolvida da socialização capitalista, depois da sociedade por ações e do monopólio".

O Estado opta, freqüentemente, por uma ação que favorece apenas uma parcela privilegiada de empresas, pessoas e instituições; amiúde aquela que representa as ações verticais próprias de setores hegemônicos empresarias ou das classes sociais mais abastadas. Contudo, pela própria necessidade, estratégica e/ou ideológica, mantém-se o discurso de ser um Estado para todos (J. Lojikine, 1997, 1977, pp. 136-137).

O Estado, em sua esfera legislativa, traz em sua constituição a criação de normas. A elaboração destas normas reflete um conjunto de intencionalidades contraditórias e conflitantes que refletem a disputa pelo uso do território seja política ou economicamente. No caso das leis eleitorais, o jogo de interesses partidários fica ainda mais evidente. A influência do executivo e das empresas também se manifesta com ferocidade, pois através o sistema político-eleitoral é determinante na disputa pelo comando político do Estado.

As prestações de contas dos partidos e candidatos ${ }^{12}$, apesar de serem pouco verdadeiras (na maioria dos casos o custo das campanhas e as quantidades doadas são muito superiores aos declarados), demonstram que as campanhas são

\footnotetext{
12 A prestação de contas do financiamento eleitoral, uma das inovações das reformas, inaugurada a partir de 1993, obteve um novo significado a partir de 2002, porque a justiça eleitoral estabeleceu que as contas eleitorais passariam a ser prestadas em formato eletrônico. Por esse motivo, a partir dessa data tornou-se possível obter um quadro razoável sobre o caixa oficial de campanhas.
} 
fortemente dependentes das doações de empresários. Em 2002, 80\% dos recursos declarados pelos candidatos à presidência da república são de doações das empresas. Além disso as doações previlegiam algumas candidaturas, "Estas não são feitas de maneira neutra: partidos pequenos de esquerda recebem muito menos do que outros. A dependência de recursos de empresas para fazer as campanhas levanta a suspeita (algumas vezes comprovada) de que determinadas políticas públicas são implementadas para favorecer alguns doadores, ou de que certas doações são retribuições a políticas que favorecem as empresas" (J. Nicolau, 2004).

Em 2004, mais de 500 construtoras e 40 bancos financiaram candidatos a prefeito e vereador em diferentes pontos do território nacional. Este dado contribui para evidenciar este estreito laço entre a política do estado e a política das empresas.

As reformas, realizadas a partir de 1993, introduziram um teto para contribuições de pessoas jurídicas e físicas (limitando doações a $2 \%$ do faturamento de empresas e a $10 \%$ do rendimento das pessoas físicas), o que de certa forma desrespeita o princípio da igualdade entre os cidadãos. Porque cidadãos ou empresas com renda mais alta estão autorizados a contribuirem mais para campanhas do que aqueles que têm rendimentos inferiores? Para B. W. Speck (2004, p. 37), "semelhante dispositivo talvez nem resista a um questionamento sério quanto a sua constitucionalidade, uma vez que transforma em norma a desigualdade dos cidadãos no processo eleitoral".

No país, cerca de 50 milhões de pessoas vivem na linha da miséria, ou seja, quase um terço dos seus cidadãos e, obviamente, não tem possibilidade alguma de contribuir financeiramente numa campanha política. Todavia, são eles que mais precisariam de um sistema de objetos e ações que lhes permitam deixar essa condição miséria que historicamente estão submetidos. Os mais que mais necessitam de ações do Estado "mais justas e para todos", são esquecidos pelos que foram eleitos por seus votos e, na maioria das vezes, sem o voto das grandes empresas mas com a contribuição de suas generosas doações e para quem, amiúde, irão governar. 
Dados oficiais sobre o montante de dinheiro investido por algumas construtoras e bancos no financiamento da campanha de 2002 demonstram como o dinheiro das empresas é distribuído seletivamente pelos partidos, pelos estados e pelos candidatos. A distribuição desse dinheiro no território está completamente vinculada à materialidade efetiva e potencial do território e seu uso futuro.

Quanto à criação ou estabelecimento dos usos, não podemos esquecer da condição de inseparabilidade entre as ações e os objetos, já mencionada anteriormente. Os objetos, enquanto trabalho morto, não agem mas tem um papel ativo uma vez que comportam a realização das ações, podendo autorizar e condicionar determinados usos. No dizer de M. Santos (1996, p. 70), os objetos "podem nascer predestinados a um certo tipo de ações, cuja plena eficácia se tornam indispensáveis. São as ações que, em última análise, definem os objetos, dando-lhes um sentido Mas hoje, os objetos 'valorizam' diferentemente as ações, em virtude de seu conteúdo técnico". Poderíamos então dizer que as ações e os objetos, sendo frutos do trabalho social, ao se geografizarem nos lugares conferemIhes novos valores, também de acordo com a equação da quantidade de trabalho e de forças produtivas que contêm. 
Tabela 5: Doações da CONSTRUTORA NORBERTO ODEBRECHT S.A. por Partido na Campanha Eleitoral 2002

\begin{tabular}{|l|r|}
\hline \multicolumn{1}{|c|}{ Partido } & \multicolumn{1}{c|}{ Valor } \\
\hline PFL & $2.091 .000,00$ \\
\hline PSDB & $1.557 .000,00$ \\
\hline PMDB & $876.000,00$ \\
\hline PT & $848.000,00$ \\
\hline PSB & $800.000,00$ \\
\hline PPS & $730.000,00$ \\
\hline PTB & $220.000,00$ \\
\hline PSDC & $170.000,00$ \\
\hline PPB & $115.000,00$ \\
\hline PL & $80.000,00$ \\
\hline PV & $50.000,00$ \\
\hline PMN & $20.000,00$ \\
\hline PC do B & $12.000,00$ \\
\hline PRP & $10.000,00$ \\
\hline TOTAL & $7.579 .000,00$ \\
\hline
\end{tabular}

Fonte: TSE, 2002.

Tabela 6: Doações da CONSTRUTORA NORBERTO ODEBRECHT S.A. por tipo de Candidatura na Campanha Eleitoral - 2002

\begin{tabular}{|l|r|}
\hline \multicolumn{1}{|c|}{ Candidatura } & \multicolumn{1}{c|}{ Valor } \\
\hline Presidente (PT, PPS) & $550.000,00$ \\
\hline $\begin{array}{l}\text { Governador (AL, BA, CE, GO, } \\
\text { MS, PA, PB, PE, RJ, RN, SC, } \\
\text { SP) }\end{array}$ & $3.267 .000,00$ \\
\hline $\begin{array}{l}\text { Senador (AL, AM, BA, CE, DF, } \\
\text { MG, MS, PE, RN) }\end{array}$ & $822.000,00$ \\
\hline $\begin{array}{l}\text { Deputado Federal (BA, CE, ES, } \\
\text { MG, MS, PB, PE, RJ, RN, SC, } \\
\text { SE, SP) }\end{array}$ & $1.855 .000,00$ \\
\hline $\begin{array}{l}\text { Deputado Estadual (BA, ES, GO, } \\
\text { MG, PE, RJ, SC, SP) }\end{array}$ & $735.000,00$ \\
\hline $\begin{array}{l}\text { Comitê Financeiro Único (BA, } \\
\text { PA) }\end{array}$ & $350.000,00$ \\
\hline TOTAL & $\mathbf{7 . 5 7 9 . 0 0 0 , 0 0}$ \\
\hline
\end{tabular}

Fonte: TSE, 2002. 
Tabela 7: Doações da CONSTRUTORA NORBERTO ODEBRECHT S.A. por Estado na Campanha Eleitoral - 2002

\begin{tabular}{|c|c|}
\hline UF & Valor \\
\hline BR & 550.000 \\
\hline$A L$ & $242.000,00$ \\
\hline BA & $1.905 .000,00$ \\
\hline CE & $450.000,00$ \\
\hline $\mathrm{PB}$ & $200.000,00$ \\
\hline $\mathrm{PE}$ & $1.026 .000,00$ \\
\hline $\mathrm{RN}$ & $250.000,00$ \\
\hline SE & $50.000,00$ \\
\hline Região Nordeste & 4.123.000,00 \\
\hline ES & $170.000,00$ \\
\hline MG & $343.000,00$ \\
\hline RJ & $578.000,00$ \\
\hline SP & $425.000,00$ \\
\hline Região Sudeste & $1.516 .000,00$ \\
\hline DF & $95.000,00$ \\
\hline GO & $200.000,00$ \\
\hline MS & $445.000,00$ \\
\hline Região Centro-Oeste & $740.000,00$ \\
\hline AM & $100.000,00$ \\
\hline PA & $400.000,00$ \\
\hline Região Norte & $500.000,00$ \\
\hline SC & $150.000,00$ \\
\hline Região Sul & $150.000,00$ \\
\hline TOTAL & $7.579 .000,00$ \\
\hline
\end{tabular}

Fonte: TSE, 2002. 
Tabela 8: Doações das CONSTRUÇÕES E COMERCIO CAMARGO CORREIA SA na Campanha Eleitoral 2002

\begin{tabular}{|c|c|c|c|c|c|}
\hline UF & Partido & Nome & Número & Candidatura & Valor \\
\hline BR & PSB & $\begin{array}{l}\text { Comitê Financeiro Nacional para } \\
\text { Presidente }\end{array}$ & - & & $1.200 .000,00$ \\
\hline BR & PPS & $\begin{array}{l}\text { Comitê Financeiro Nacional para } \\
\text { Presidente }\end{array}$ & - & & $170.000,00$ \\
\hline \multicolumn{5}{|c|}{ TOTAL NACIONAL } & $1.370 .000,00$ \\
\hline PA & PSDB & SEBASTIÃO PEREIRA DA SILVA & 45222 & Deputado Estadual & $10.000,00$ \\
\hline SP & PSDB & ALOYSIO NUNES FERREIRA FILHO & 4521 & Deputado Federal & $205.000,00$ \\
\hline SP & PSDB & $\begin{array}{l}\text { GERALDO JOSE RODRIGUES ALCKMIN } \\
\text { FILHO }\end{array}$ & & Governador & $2.000,00$ \\
\hline RJ & PSB & $\begin{array}{l}\text { ROSANGELA BARROS ASSED } \\
\text { MATHEUS DE OLIVEIRA }\end{array}$ & & Governador & $200.000,00$ \\
\hline SC & PFL & $\begin{array}{l}\text { PAULO ROBERTO BARRETO } \\
\text { BORNHAUSEN }\end{array}$ & 252 & Senador & $100.000,00$ \\
\hline \multicolumn{5}{|c|}{ TOTAL - ESTADOS } & $517.000,00$ \\
\hline \multicolumn{5}{|c|}{ TOTAL DAS DOAÇÕES } & $1.887 .000,00$ \\
\hline
\end{tabular}

Fonte: TSE, 2002. 
Tabela 9: Doações do BANCO ITAÚ por Estado na Campanha Eleitoral - 2002

\begin{tabular}{|c|c|c|c|}
\hline \multicolumn{3}{|c|}{ Doador: Banco Itaú S.A. } & \multirow{2}{*}{$\begin{array}{l}7.055 .254,68 \\
\text { Valor }\end{array}$} \\
\hline UF & Partido & Nome & \\
\hline BR & PT & $\begin{array}{l}\text { Comitê Financeiro Nacional para } \\
\text { Presidente }\end{array}$ & $250.000,00$ \\
\hline \multirow[t]{2}{*}{$\mathrm{BR}$} & PSDB & $\begin{array}{l}\text { Comitê Financeiro Nacional para } \\
\text { Presidente }\end{array}$ & $2.200 .000,00$ \\
\hline & & TOTAL NACIONAL & $2.450 .000,00$ \\
\hline \multicolumn{3}{|l|}{ MG } & $445.000,00$ \\
\hline \multicolumn{3}{|l|}{ RJ } & $220.000,00$ \\
\hline \multicolumn{3}{|l|}{ SP } & $1.370 .022,80$ \\
\hline \multicolumn{3}{|r|}{ REGIÃO SUDESTE } & $2.035 .022,80$ \\
\hline \multicolumn{3}{|l|}{ BA } & $75.000,00$ \\
\hline \multicolumn{3}{|l|}{ CE } & $100.000,00$ \\
\hline \multicolumn{3}{|l|}{ MA } & $100.000,00$ \\
\hline \multicolumn{3}{|l|}{ PB } & $40.000,00$ \\
\hline \multicolumn{3}{|l|}{ PE } & $520.000,00$ \\
\hline \multicolumn{3}{|l|}{$\mathrm{PI}$} & $40.000,00$ \\
\hline \multicolumn{3}{|l|}{$\mathrm{RN}$} & $240.000,00$ \\
\hline \multicolumn{3}{|r|}{ REGIÃO NORDESTE } & $1.115 .000,00$ \\
\hline \multicolumn{3}{|l|}{ PR } & $300.231,88$ \\
\hline \multicolumn{3}{|l|}{ RS } & $650.000,00$ \\
\hline \multicolumn{3}{|r|}{ REGIÃO SUL } & $950.231,88$ \\
\hline \multicolumn{3}{|l|}{ DF } & $100.000,00$ \\
\hline \multicolumn{3}{|l|}{ GO } & $105.000,00$ \\
\hline \multicolumn{3}{|l|}{ MS } & $200.000,00$ \\
\hline \multicolumn{3}{|r|}{ REGIÃO CENTRO-OESTE } & $405.000,00$ \\
\hline \multicolumn{3}{|l|}{ AM } & $100.000,00$ \\
\hline & & REGIÃO NORTE & $100.000,00$ \\
\hline & TOTAIS & ESTADUAIS & $4.605 .254,68$ \\
\hline
\end{tabular}

Fonte: TSE, 2002. 
Tabela 10: Doações do BANCO ITAÚ por tipo de Candidatura na Campanha Eleitoral - 2002

\begin{tabular}{|c|c|c|c|}
\hline Candidatura/Comitê & $\begin{array}{l}\text { número de } \\
\text { candidatos }\end{array}$ & Estados & Valor \\
\hline & & & $7.055 .254,68$ \\
\hline $\begin{array}{l}\text { Comitê Financeiro Nacional para } \\
\text { Presidente (PT) }\end{array}$ & & & $250.000,00$ \\
\hline $\begin{array}{l}\text { Comitê Financeiro Nacional para } \\
\text { Presidente (PSDB) } \\
\end{array}$ & & & $2.200 .000,00$ \\
\hline Governador & 5 & $\begin{array}{l}\text { MG, MS, RN, SP, } \\
\text { PE }\end{array}$ & $1.000 .000,00$ \\
\hline Senador & & $9 \begin{array}{l}\text { AM, DF, MG, MS, } \\
\text { PE, RJ, RN, SP }\end{array}$ & $1.080 .000,00$ \\
\hline Deputado Estadual & 7 & MG, PR, SP & $130.254,68$ \\
\hline Deputado Federal & 32 & $\begin{array}{l}\text { BA, CE, GO, MA, } \\
\text { MG, PB, PE, PI, RJ, } \\
\text { RN, RS, SP }\end{array}$ & $1.495 .000,00$ \\
\hline Comitê Financeiro Único & 3 & RS, PR & $900.000,00$ \\
\hline
\end{tabular}

Fonte: TSE, 2002.

Tabela 11: Doações do BANCO ITAÚ por Partido na Campanha Eleitoral - 2002

\begin{tabular}{|l|r|}
\hline Partido & \multicolumn{1}{|c|}{ Valor } \\
\hline PSDB & $3.520 .022,80$ \\
\hline PFL & $1.120 .000,00$ \\
\hline PMDB & $630.000,00$ \\
\hline PPB & $595.000,00$ \\
\hline PT & $390.000,00$ \\
\hline PDT & $300.231,88$ \\
\hline PPS & $220.000,00$ \\
\hline PTB & $180.000,00$ \\
\hline PL & $60.000,00$ \\
\hline PSDC & $40.000,00$ \\
\hline & $7.055 .254,68$ \\
\hline
\end{tabular}

Fonte: TSE, 2002. 
Há ainda que mencionar, conforme nos sugere M. Santos (1996, p. 70), que existe, "em cada momento, uma relação entre valor da ação e o valor do lugar onde ela se realiza; sem isso, todos os lugares teriam o mesmo valor de uso e o mesmo valor de troca, valores que não seriam afetados pelo movimento da história".

Tabela 12: Doações da ARACRUZ CELULOSE S.A. na Campanha Eleitoral - 2002

\begin{tabular}{|l|c|c|c|c|r|}
\hline & BR & BA & ES & PE & \multicolumn{1}{c|}{ TOTAL } \\
\hline PFL & - & $1.050 .000,00$ & $170.000,00$ & - & $1.220 .000,00$ \\
\hline PSDB & $379.762,63$ & $80.000,00$ & $245.000,00$ & - & $704.762,63$ \\
\hline PSB & - & - & $670.000,00$ & - & $670.000,00$ \\
\hline PMDB & - & - & $450.000,00$ & $150.000,00$ & $600.000,00$ \\
\hline PTB & - & - & $470.000,00$ & - & $470.000,00$ \\
\hline PPB & - & $20.000,00$ & $415.000,00$ & - & $435.000,00$ \\
\hline PL & - & $120.000,00$ & $120.000,00$ & - & $240.000,00$ \\
\hline PPS & - & - & $240.000,00$ & - & $240.000,00$ \\
\hline PT & $50.000,00$ & - & $70.000,00$ & - & $120.000,00$ \\
\hline PGT & - & - & $50.000,00$ & - & $50.000,00$ \\
\hline PDT & - & - & $30.000,00$ & - & $30.000,00$ \\
\hline PMN & - & - & $20.000,00$ & - & $20.000,00$ \\
\hline & $429.762,63$ & $1.270 .000,00$ & $2.950 .000,00$ & $150.000,00$ & $4.799 .762,63$ \\
\hline
\end{tabular}

Fonte: TSE, 2002.

A territorialização do debate da reforma política se evidencia pelo interesse de empresas ou grupos econômicos em investir na campanha eleitoral de um candidato nos diversos distritos eleitorais. Se compararmos o custo e as empresas financiadoras de uma campanha, como aparece nos casos selecionados, verificamos que os interesses empresariais são quantitativa e qualitativamente distintos, manifestando diferentes valorizações dos lugares de acordo com seus interesses corporativos.

Frente à situação atual, a proposta da Comissão de Reforma Política é proibir que os candidatos recebam recursos privados e passem a fazer campanhas 
exclusivamente com recursos públicos, como uma tentativa de tentar inibir essa estreita ligação entre candidato e doador, ou seja, interesses corporativos.

A utilização do financiamento público tem seu início a partir da década de 1950 e sua ocorrência se dá em vários países. Atualmente, são poucos países que não conhecem alguma forma de subsidio público aos partidos, seja na forma de acesso gratuito ao rádio e à televisão, isenção tributária ou recursos em espécies dos cofres públicos. Segundo J. Nicolau (2004), "o Brasil já oferece um generoso subsídio de campanha, o horário eleitoral gratuito, que custa aos cofres públicos cerca de 1 bilhão, pois as redes de rádio e televisão recebem isenção fiscal pelo tempo ocupado pelos candidatos".

O projeto propõe que seja criado um fundo (que em valores atuais seria de 810 milhões) para financiar também os gastos de campanha (A. O. CINTRA, 2005, p. 11) Porém, para B. W. Speck (2004, p. 36), "não há hoje país que tenha introduzido o financiamento público como forma de substituir completamente o financiamento privado em todas as suas modalidades. A Alemanha, freqüentemente citada neste contexto, caracteriza-se por combinar o financiamento público pesado com praticamente nenhum limite quanto ao financiamento privado".

O financiamento público de campanha é tratado de modo radical no $\mathrm{PL} \mathrm{n}^{\circ}$ 2.679/03, cujo texto não sofreu modificação no Substitutivo. Importa assinalar que a idéia de financiamento público exclusivo já era objeto de projetos em tramitação na Câmara e no Senado, dos quais se aproveitaram os pontos básicos.

Os pontos centrais da proposta, apresentada no (Projeto Lei $n^{\circ} 2.679 / 03$ ), são:

\footnotetext{
“a) as despesas eleitorais serão realizadas sob a responsabilidade dos partidos e federações. Portanto, a nova figura, federação, é equiparada aos partidos no que concerne aos gastos de campanha,

b) a lei orçamentária, em ano eleitoral, terá dotação equivalente ao número de eleitores do País em 31/12 do ano anterior, multiplicado por $\mathrm{R} \$ 7,00$. Tal dispositivo poria, com números de 2004, um total de 800 milhões de reais à disposição das campanhas eleitorais.
}

c) O TSE fará a distribuição dos recursos às direções nacionais dos partidos. O critério para distribuição entre os partidos é o seguinte: $1 \%$ dividido igualitariamente entre 
todos os partidos com estatutos registrados no TSE; $14 \%$ divididos igualitariamente entre os partidos e federações com representação na Câmara dos Deputados e 85\% divididos proporcionalmente ao número de representantes que elegeram na última eleição geral para a Câmara dos Deputados. Um exemplo dos montantes de recursos, caso a lei estivesse em vigor, está apresentado no anexo, num pequeno estudo que fizemos. Por sua vez, os recursos acima mencionados deverão aplicar-se segundo os seguintes critérios, conforme discrimina o Projeto:

I - nas eleições presidenciais, federais e estaduais, quando o partido ou a federação tiverem candidato próprio a Presidente da República, os diretórios nacionais dos partidos políticos e a direção nacional de cada federação reservarão trinta por cento dos recursos para sua administração direta;

II - se o partido ou federação não tiver candidato próprio a Presidente da República, mesmo concorrendo em coligação, os respectivos diretórios nacionais reservarão vinte por cento dos recursos para sua administração direta;

III - nas hipóteses dos incisos I e II, os diretórios nacionais dos partidos ou federações distribuirão os recursos restantes aos diretórios regionais, sendo:

a. metade na proporção do número de eleitores de cada Estado, do Distrito Federal e de cada Território; e

b. metade na proporção das bancadas dos Estados, do Distrito Federal e dos Territórios, que o partido ou federação elegeu para a Câmara dos Deputados.

IV - nas eleições municipais, os diretórios nacionais dos partidos políticos ou a direção nacional de cada federação reservarão dez por cento dos recursos para sua administração direta e distribuirão os noventa por cento restantes aos diretórios regionais, conforme critérios estabelecidos nas alíneas a e b do inciso III.

$V$ - dos recursos recebidos pelos diretórios regionais, dez por cento serão reservados para a sua administração direta e os noventa por cento restantes serão distribuídos aos diretórios municipais, sendo:

a. metade na proporção do número de eleitores do município; e

b. metade na proporção do número de vereadores eleitos pelo partido político ou federação, no município, em relação ao total de vereadores eleitos pelo partido político ou federação no Estado.(NR)".

Como pode ser observado acima, o projeto estabelece um complexo sistema de distribuição dos recursos levando em conta a representatividade dos partidos, beneficiando a manutenção de um campo de forças e de poder partidários 
já estabelecido. A tabela abaixo apresenta o cálculo com os recursos destinados aos quatro principais partidos para as eleições de 2006, caso o projeto tivesse em vigor.

\begin{tabular}{|l|l|}
\hline Partido & Recursos (R\$) \\
\hline PT & 132 milhões \\
\hline PSDB & 104 milhões \\
\hline PFL & 98 milhões \\
\hline PMDB & 98 milhões \\
\hline
\end{tabular}

Extraído de J. Nicolau (2004).

Uma das questões que se levanta sobre a implantação de financiamento público exclusivo é a de sua associação à instituição da lista preordenada, garantindo-se, dessa forma, sua viabilidade efetiva. A defesa das propostas casadas alega que seriam muitas as dificuldades para se estabelecer critérios de distribuição dos recursos públicos entre cada um dos candidatos no sistema de lista aberta; já no caso da lista preordenada os recursos seriam repassados aos partidos.

Para C. Siqueira (2002, p. 13), primeiro-secretário nacional do Partido Socialista Brasileiro, "a proposta que tramita no Congresso, a meu ver, está apresentada de maneira insuficiente porque ao mesmo tempo que propõe financiamento público, não cria um mecanismo de controle social capaz de evitar que, de modo ilegal, haja o financiamento público e ao mesmo tempo o financiamento privado. $\mathrm{O}$ projeto precisa ser aperfeiçoado no sentido de garantir $100 \%$ de financiamento público da campanha, criando-se, então, uma norma clara que penalize de modo determinante as candidaturas que, eventualmente, venham a receber recursos privados para suas campanhas, inclusive com um dispositivo que garanta a cassação da candidatura mesmo que já registrada".

A questão então que se coloca quanto à proposta do financiamento público refere-se à sua real eficácia em se acabar ou minimizar as manipulações e pressões, muitas vezes ilícitas, gerada pela política das empresas neste casamento vil com a política do Estado, que tem produzido um uso do território com oportunidades tão desiguais aos seus integrantes. 
Acreditamos que o financiamento público fecha algumas portas de manipulação e pressão, mas nem todas. Ele de fato exclui a possibilidade de contribuições privadas declaradas e, talvez, possa limitar o caixa dois dos candidatos individuais. Contudo, de forma alguma, o financiamento público elimina o financiamento empresarial e oculto dos partidos.

Ao que parece o financiamento público eliminaria as contribuições privadas declaradas, todavia isso poderia contribuir, ao mesmo tempo negativamente, ocultando os vínculos corporativos dos candidatos e partidos.

O quadro de A. O. Cintra (2005, pp. 18-20) oferece um panorama dos principais argumentos favoráveis e contrários a financiamento público exclusivo. 


\begin{tabular}{|c|c|c|}
\hline & Argumentos favoráveis & Argumentos contrários \\
\hline $\begin{array}{l}\text { Financiamento } \\
\text { público } \\
\text { exclusivo }\end{array}$ & $\begin{array}{l}\text { 1. Trata-se de sistema mais republicano e } \\
\text { democrático. Iguala as chances dos candidatos, } \\
\text { pobres e ricos. } \\
\text { 2. Reduzirá a influência eleitoral dos } \\
\text { financiadores, cujo apoio implica reciprocidade da } \\
\text { parte do candidato eleito. } \\
\text { 3. Protegerá os partidos e a política da influência } \\
\text { do crime organizado, o qual tem buscado, } \\
\text { mediante o financiamento de candidatos, ganhar } \\
\text { poder político. } \\
\text { 4. O financiamento público, acompanhado por } \\
\text { rigoroso sistema de fiscalização e de severas } \\
\text { punições, é a melhor opção que temos para sair } \\
\text { do péssimo sistema de financiamento em vigor no } \\
\text { país. Os benefícios para a democracia brasileira } \\
\text { compensam em muito as possíveis imperfeições } \\
\text { que o financiamento público possa ter. Até } \\
\text { mesmo a pior delas, a continuidade residual do } \\
\text { caixa dois (Jairo Nicolau, em O Globo). "A sombra } \\
\text { da corrupção fica mais nítida no pano de fundo } \\
\text { dos recursos oficiais" (Roberto Romano, Folha de } \\
\text { São Paulo). } \\
\text { 5. A tarefa de fiscalização de gastos de } \\
\text { campanha pela Justiça Eleitoral é praticamente } \\
\text { impossível na atual sistemática, dadas as } \\
\text { prestações de contas individuais por milhares de } \\
\text { candidatos. Contas partidárias serão em número } \\
\text { infinitamente menor, perfeitamente administrável } \\
\text { pelos auditores, e trarão veracidade ao processo } \\
\text { eleitoral. } \\
\text { 6. Apesar do custo do financiamento público, } \\
\text { haverá ganho para o País. A menor dependência } \\
\text { do parlamentar de conquistar o máximo possível } \\
\text { de votos individuais, resultado do voto em lista, } \\
\text { acarretará melhoria na elaboração e execução do } \\
\text { orçamento. Eliminar-se-á a necessidade de } \\
\text { pulverizar recursos, para atender aos pleitos } \\
\text { individuais dos parlamentares, e permitirse-ão } \\
\text { despesas planejadas mais racionalmente, em } \\
\text { projetos de maior impacto regional, negociadas } \\
\text { não individualmente, mas pelos partidos. }\end{array}$ & 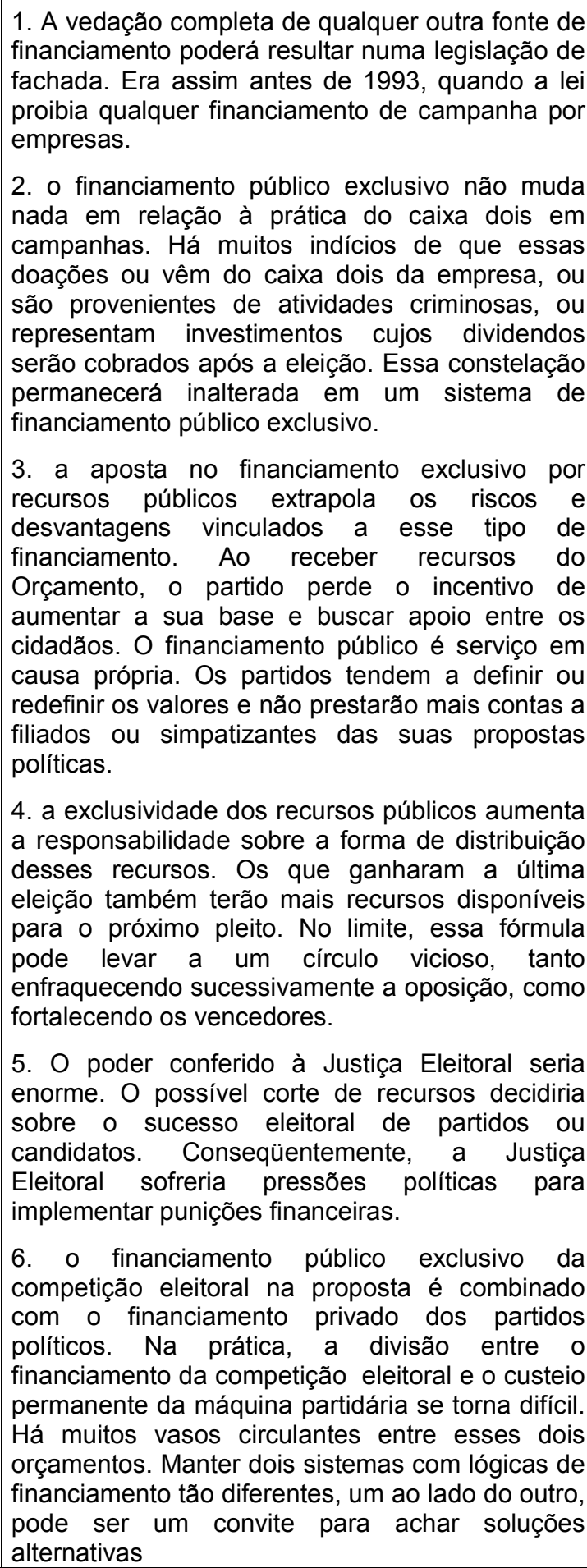 \\
\hline
\end{tabular}




\subsection{Nacionalização do partidos e a proporcionalidade territorial das representações políticas}

A desigualdade da representação dos Estados e do Distrito Federal na Câmara dos Deputados apesar de não constar no projeto de reforma política apresentado pela Comissão, aparece freqüentemente na literatura que trata do tema da reforma política, como sendo essencial ao aperfeiçoamento da democracia brasileira.

Para muitos políticos e intelectuais, o sistema representativo brasileiro fere o principio elementar da democracia representativa, ou seja, cada pessoa um voto, porque quando um cidadão muda de domicílio eleitoral, por exemplo do Estado de Roraima para o Estado de São Paulo, o peso específico do seu voto, nas eleições para a Câmara dos Deputados, é reduzido de forma significativa.

São Paulo tem direito a 70 cadeiras na Câmara Federal, enquanto Roraima apenas 8. Mas se dividirmos o número de representantes pelo de eleitores de cada Estado, verifica-se uma distorção.

O tema em debate aponta para o problema existente na representação que é o da sobre-representação de quatro estados da Região Norte: Roraima, Amapá, Acre e Tocantins.

Segundo A. F. de Oliveira (2003, p. 77), a solução para essa situação, através de uma mudança constitucional, contempla duas possibilidades: a redução do número mínimo de representantes por Estado de oito para quatro ou a elevação do número máximo de setenta para cem, neste caso ampliando-se em igual número a composição total da Câmara. "A elevação do número de representantes de São Paulo de setenta para noventa ou cem já é bastante para, desprezando detalhes aritméticos e concentrando-se na questão política essencial, equacionar a matéria de maneira razoável, evitando eventuais diferenças, que remanesçam, à conta do princípio federativo". 


\section{CONCLUSÃo}

Enfocando os lugares a partir da totalidade da qual participam, "cada lugar constitui na verdade uma fração do espaço total, pois só esse espaço total é o objeto da totalidade das relações exercidas dentro de uma sociedade, em um dado momento. Cada lugar é objeto de apenas algumas dessas relações 'atuais' de uma dada sociedade e, através dos seus movimentos próprios, apenas participa de uma fração do movimento social total” (M. Santos, 1992, 1985, p. 18).

O mundo tomado como totalidade contém as possibilidades de um período. Estas possibilidades se concretizam seletivamente nos lugares. Conforme a constituição interna e dinâmica externa de cada lugar ou região, esta ou aquela possibilidade do mundo torna-se um evento ganhando existência efetiva.

Os usos diversos associam-se a comandos diversos que incidem sobre os lugares. "As ações são cada vez mais estranhas aos fins próprios do homem e do lugar. Daí a necessidade de operar uma distinção entre a escala de realização das ações e a escala de seu comando. Essa distinção se torna fundamental no mundo de hoje: muitas das ações que se exercem num lugar são produto de necessidades alheias, de funções cuja geração é distante e das quais apenas a resposta é localizada naquele ponto preciso da superfície da terra” (M. Santos, 1996, p. 65).

Neste período da chamada globalização, assim como as técnicas, as normas são freqüentemente portadoras de uma ordem externa, seja global ou mesmo nacional, aos lugares. Como um vetor externo, tais normas atingem os lugares condicionando ações locais a partir de comandos homogeneizadores exógenos. Todavia, para M. L. Silveira (2000, p. 123), “a ordem global enfrenta uma profunda contradição que lhe impede de concretizar a pretensa homogeneidade. [...] A evolução técnica com suas permanentes inovações, a crescente especialização e obsolescência dos objetos e a difusão da informação-segredo e da informação banal questionam, a cada dia, a validade das normas nas regiões e nos países".

No início da década de 1990, ao considerar os espaços do mandar e os espaços do fazer, M. Santos (1994b, p. 107) parece perguntar-se sobre o papel que a diferente constituição dos espaços, incluindo as racionalidades correspondentes, 
teria sobre o voto de determinada região ou lugar? Menciona que as áreas opacas, aquelas menos modernas, podem acolher, de um ponto de vista geográfico, "contraracionalidades" e, do ponto de vista social, as minorias (M. Santos, 1994b, p. 107).

Quando se definem novas normas, autorizam-se novos usos. Todavia, a uma distância entre a prescrição e sua efetiva realização. Concebidas muitas vezes longe da vida dos lugares, as normas tornam-se vetores externos que atingem-nos imprimindo novos usos. Todavia, os lugares pela sua materialidade e a seu uso acolhem as normas metamorfoseando-as, geografizando-as. Quando se modifica a forma de eleger um candidato, por ex. não mais um eleitor escolhe a pessoa em que vota e sim o partido, isso terá diferentes manifestações nos distintos cantos do país. Regiões onde existem mais números de filiados e maior participação partidária podem produzir resultados eleitorais mais benéficos às necessidades dos lugares do que em regiões sem participação das pessoas nas instituições partidárias, onde as pessoas não reconhecem os candidatos escolhidos pelos partidos. Ou, regiões que já apresentam uma "distritalização informal do voto" pode ter sua representação territorial completamente modificada por essa norma diferentemente daquelas porções do território onde a expressão territorial do voto já é mais dispersa.

As normas, então, geografizam-se seletivamente nos lugares. Esta geografização das normas revela também o papel ativo dos lugares de acordo com sua maior ou menor força de resistência frente aos vetores hegemônicos, sejam nacionais ou globais.

Estamos entendendo a Reforma Política como parte dos pactos territoriais, uma vez que M. Santos (1987) menciona como exemplo destes pactos, entre outros, a mudança na distribuição de cadeiras da Câmara Federal uma vez que tal medida modifica a representatividade dos Estados e da população.

Desse modo, para pensarmos a Reforma Política acreditamos ser necessário estar atento à diferenciação feita por $M$. Santos quanto à natureza dos pactos territoriais: funcional ou estrutural. Para M. Santos (1987, p. 105) "pactos funcionais interessam a parcelas da população e a interesses localizados, mas não atingem o âmago das relações sociais fundamentais. Criar um novo município, por 
exemplo, pode atender a interesses eleitorais (ocasionais) de um partido ou a interesses financeiros de um grupo. O mesmo se pode dizer em relação ao surgimento de novos Estados e Territórios. O que faz falta é a proposição de um pacto territorial estrutural, conjunto de propostas visando a um uso do território coerente com um projeto de país e parte essencial deste projeto".

Qual é a natureza da atual Reforma Política? Será mais um pacto funcional ou algumas de suas proposições podem significar um pacto territorial estrutural? Poderá contribuir ou não para a implantação de uma democracia que não seja apenas eleitoral ${ }^{13}$ ? Como uma nova regulamentação eleitoral, autorizando novas formas do fazer político-eleitoral se geografizará nos lugares?

\footnotetext{
${ }^{13}$ M. Santos (2000, p. 139) distingue a democracia apenas eleitoral da democracia econômica, social e política.
} 


\section{BIBLIOGRAFIA}

AMARAL, Roberto. "Apontamentos para a Reforma Política. A democracia representativa está morta; viva a democracia participativa", in Revista de Informação Legislativa, ano 38, n. 151, Brasília, jul./set. 2001.

AMORIM, Miriam Campelo de Melo e Antônio Octávio CINTRA. Breve Histórico das Reformas Políticas durante a 51a. Legislatura na Câmara dos Deputados, Câmara dos Deputados, Brasília, fevereiro de 2003.

ANDRADE, Manuel Correia de. A questão do território no Brasil, Hucitec, São PauloRecife, 1995.

BARRETO, Leonardo. "Reforma Política: o risco da adoção das listas fechadas. O exemplo da Venezuela", in Revista do Curso de Direito, v. 4, n² 2, AEUDF, ICS, Brasília, julho-dezembro 2003, pp. 77-87.

BOBBIO, Norberto. Teoria da norma jurídica, EDIPRO, São Paulo, 2001.

CARVALHO, Katia de. Cláusula de barreira e funcionamento parlamentar, Câmara dos Deputados, Brasília, fevereiro de 2003.

CINTRA, Antônio Octávio. A proposta de Reforma Política: prós e contras, Câmara dos Deputados, Brasília, janeiro de 2005.

COSTA, Wanderley Messias da. Geografia política e geopolítica, Hucitec-Edusp, São Paulo, 1992.

DIRCEU, José de Oliveira e Silva e Marcus lanoni. Reforma política. Instituições e democracia no Brasil, Atual, Fundação Perseu Abramo, São Paulo, 1996.

GOGUEL, François. "Géographie électorale et science politique: un itinéraire", in Jacques LÉVY (org.), Géographies du polititique, Fondation Nationale des Sciences Politiques, Paris, 1991.

KELSEN, Hans [1960]. Teoria Pura do Direito, 6ª ed., Martins Fontes, São Paulo, 1998.

KOSIK, Karel. Dialética do concreto. $2^{a}$ ed., Paz e Terra, Rio de Janeiro, 1976 (1963). 
LATOUR, Bruno [1991]. Jamais fomos modernos, Editora 34, São Paulo, 1997.

LÊNIN, V.I.[1917] O Estado e a Revolução, Hucitec, São Paulo, 1987.

LIMA JÚNIOR, Olavo Brasil. Instituições políticas democráticas: o segredo da legitimidade, Jorge Zahar, Rio de Janeiro, 1997.

LOJKINE, Jean [1977] O Estado capitalista e a questão urbana, $2^{\mathrm{a}}$. ed. Martins Fontes, São Paulo, 1997

MOISÉS, José Álvaro. Os brasileiros e a democracia: bases sócio-politicas da legitimidade democrática, Ática, São Paulo, 1995.

NETO, Edgard Leite Ferreira. Os partidos políticos no Brasil, $3^{\mathrm{a}}$ edição, Contexto, São Paulo, 1995.

NICOLAU, Jairo Marconi. Multipartidarismo e democracia, Fundação Getulio Vargas, Rio de Janeiro, 1996.

NICOLAU, Jairo Marconi. Sistemas eleitorais, Fundação Getulio Vargas, Rio de Janeiro, 1999.

NICOLAU, Jairo. "A reforma da representação proporcional no Brasil", in: Maria Victoria BENEVIDES, Paulo VANNUCHI, Fabio KERCHE (orgs.), Reforma política e cidadania, Instituto Cidadania, Fundação Perseu Abramo, São Paulo, 2003.

NICOLAU, Jairo. "Receita para reduzir escândalos", in O Globo, seção Opinião, Rio de Janeiro, 4 março 2004.

NOHLEN, Dieter. Sistemas electorales y partidos políticos, Universidad Nacional Autónoma de México, Fondo de Cultura Económica, México, 1994.

OLIVEIRA, Arlindo Fernandes de. "Mitos sobre a Reforma Política", in UnB Revista, Ano III, $n^{\circ}$ 8, Universidade de Brasília, Brasília, julho-outubro 2003, pp. 7477.

RABAT, Márcio Nuno. A que se refere a expressão "Reforma Política" nas discussões em curso no Congresso Nacional, Relatório Especial, Câmara dos Deputados, Brasília, agosto 2002. 
RAFFESTIN, Claude. Por uma geografia do poder, Ática, São Paulo, 1993.

RODRIGUES, Almira. "Reforma Política e participação", in Democracia Viva, n 23 , Ibase, agosto-setembro 2004, pp. 3-7.

SANGUIN, André-Louis. "A evolução e a renovação da geografia política", in Boletim Geográfico, 35(252), Rio de Janeiro, jan./mar. 1977, pp. 5-23.

SANTOS, Boaventura de Souza [1995]. Pela mão de Alice: o social e o político na pós-modernidade, $9^{\mathrm{a}}$ ed., Cortez, São Paulo, 2003.

SANTOS, Milton [1985]. Espaço \& Método, $3^{\text {a }}$ ed., Nobel, São Paulo, 1992.

SANTOS, Milton. Espaço do cidadão, Nobel, São Paulo, 1987.

SANTOS, Milton. "O espaço: sistema de objetos, sistemas de ações", in Anais do IV Encontro Nacional da ANPUR, Salvador, 1991, pp. 35-39.

SANTOS, Milton. "O Retorno do Território", in Milton SANTOS; Maria Adélia de Souza e Maria Laura Silveira (Orgs.), Território: globalização e fragmentação, Hucitec-Anpur, São Paulo, 1994a.

SANTOS, Milton. Técnica, espaço, tempo. Globalização e meio técnico-científicoinformacional, Hucitec, São Paulo, 1994b.

SANTOS, Milton. A natureza do espaço. Técnica e tempo. Razão e emoção. Hucitec, São Paulo, 1996.

SANTOS, Milton. "Globalização, espaço e democracia", in Estudos. Cadernos do Centro de Estudos e Pesquisas do Vale do Piracicaba, Gráfica e Editora Alves LTDA, Piracicaba, 1998.

SANTOS, Milton. Por uma outra globalização. Do pensamento único à consciência universal, Record, Rio de Janeiro, 2000.

SANTOS, Milton e María Laura SILVEIRA. O Brasil: território e sociedade no início do século XXI, Record, Rio de Janeiro, 2001.

SARTRE, Jean Paul [1957]. Questão de método. Difusão Européia do Livro, São Paulo, 1967. 
SCHMITT, Rogério. Partidos políticos no Brasil (1945-2000), Jorge Zahar Editor, Rio de Janeiro, 2000.

SILVEIRA, Maria Laura [1997]. Um país, uma região. Fim de século e modernização na Argentina. Laboplan-USP, FAPESP, São Paulo, 1999.

SILVEIRA, María Laura. "Imperio de la escala, escala del imperio", in Revista Universitaria de Geografia, vol. 8, $n^{o s} 1$ e 2, Departamento de Geografía, Universidad Nacional del Sur, 1999b, pp. 105-113.

SILVEIRA, María Laura. "O espaço da globalização: usos diversos, comando único", in Alvaro José de SOUZA et al. (orgs.), Milton Santos: cidadania e globalização, Saraiva, São Paulo, AGB, Bauru, 2000, pp. 121-127.

SILVEIRA, María Laura. "A questão da política: normas e ações no uso atual do território", aula ministrada no Curso de Pós-Graduação "Questões de Método em Geografia", Departamento de Geografia, Universidade de São Paulo, $2^{\circ}$ semestre de 2003 (mimeo).

SIQUEIRA, Carlos. "A reforma política que o Brasil necessita", in Senatus, v. 2, nº 1 , Senado Federal, Brasília, dezembro 2002, pp. 11-13.

SOUZA, Maria Adélia Aparecida de (org.). Território Brasileiro: usos e abusos, Territorial, Campinas, 2003.

SOUZA, Maria Adélia Aparecida de; Márcio Antônio CATAIA; Rubens de TOLEDO JUNIOR, Território, lugar e poder. A expressão territorial do voto no Ceará, Edições UVA, Sobral; Territorial, Campinas, 2002.

SPECK, Bruno Wilhelm. "Cinco teses sobre o financiamento da competição política e a proposta da respectiva Reforma", in Revista Jurídica Consulex, Ano VIII, $n^{\circ}$ 179, 30 junho 1994, pp. 35-37.

TAYLOR, Peter J. Geografía política: economía mundo, estado-nación y localidad, Trama Editorial, Madrid, 1994. 


\section{GLOSSÁRIO}

\section{Sistemas Eleitorais}

J. M. Nicolau (1999, p. 10) define sistemas eleitorais como "os mecanismos responsáveis pela transferência dos votos dados pelos eleitores no dia das eleições em mandatos".

Segundo os especialistas, grosso modo, existem dois grandes modelos de sistema eleitoral: o proporcional e o majoritário. Há também um terceiro tipo híbrido: o sistema misto, que resulta da combinação de elementos dos dois sistemas anteriores.

\subsection{Sistema majoritário}

A representação majoritária tem por objetivo eleger o candidato mais votado, estabelecendo assim, de forma geral, um representante para cada distrito eleitoral, ou seja, para cada unidade territorial previamente definida (Estado, país, município etc.), em que os votos dos eleitores convertem-se em assentos parlamentares ou cargos executivos.

É importante destacar que no interior de cada um dos sistemas de representação existem variações. A família dos sistemas majoritários é composta por quatro tipos: maioria simples, dois turnos, voto alternativo e voto em bloco. Os dois primeiros destacam-se por serem mais utilizados.

No sistema de maioria simples a eleição se dá em um único turno, e, é eleito o candidato que obtiver mais votos em um distrito eleitoral, que deve ter apenas um representante.

O sistema de dois turnos também se dá em distrito eleitoral de um único representante. Os partidos concorrentes apresentam apenas um candidato e a escolha o eleitorado é também por um único nome. Nesse sistema o candidato 
precisa obter a maioria absoluta dos votos, ou seja, mais de $50 \%$. Caso isso não ocorra, é realizada uma nova eleição e o candidato será eleito em segundo turno.

Os defensores desse sistema argumentam que ele possibilita uma relação estreita ou direta entre o representado e o representante, pois pode facilitar o acompanhamento das propostas apresentadas durante a campanha eleitoral pelo candidato, assim como o desempenho do representante durante o seu mandado. Destacam, segundo (J. M. Nicolau, 1999, p.10), que a representação majoritária tem a "capacidade de produzir governos unipartidários" e "uma capacidade maior de controle dos representantes pelos representados e a representação territorial".

\subsection{Sistema proporcional}

O sistema proporcional busca a eqüidade na relação entre os votos recebidos pelos partidos e as cadeiras parlamentares ocupadas por cada um deles, de modo que a distribuição dos postos legislativos corresponda, aritmeticamente, ao desempenho eleitoral das diversas correntes organizadas, majoritárias ou minoritárias, que concorrem no pleito. Difere do sistema majoritário, cujo princípio é a eleição do representante partidário mais votado.

O sistema proporcional visa "garantir que um partido que receba $10 \%$ dos votos ocupe aproximadamente $10 \%$ das cadeiras, o que recebe $20 \%$ ocupe aproximadamente $20 \%$ e assim por diante, para assegurar a representação fiel da pluralidade de opiniões da sociedade ou dos partidos expressa nos votos dos eleitores" (J. Dirceu e lanoni, 1999, p. 22).

Para J. M. Nicolau (1999, p. 10) "o princípio dos sistemas proporcionais tenciona distribuir os postos em disputa de maneira equânime à votação obtida pelos competidores. Desta forma, os defensores da representação proporcional destacam a capacidade de se produzir uma relação equânime entre votos e cadeiras e a necessidade de o parlamento garantir a representação de minorias". 
A representação proporcional pode operar de duas maneiras: por intermédio da representação proporcional de lista e pelo sistema de voto único transferível (STV).

O sistema de voto único transferível (STV) assegura a representação das opiniões individuais. Nele é permitido ao eleitor a possibilidade de escolha não só de partidos mas principalmente de seus representantes individuais.

Este sistema é o que permite o maior grau de escolha por parte dos eleitores, que podem votar em candidatos de diferentes partidos e ainda ordená-los de acordo com sua preferência.

Já o sistema de representação proporcional de lista, pretende garantir a representação das opiniões expressas da sociedade por intermédio dos partidos políticos. Assim, cada partido apresenta uma lista de candidatos para uma dada eleição, a partir de procedimentos previamente definidos. Os votos são contados para o partido e distribuem-se as cadeiras parlamentares disputadas, de acordo com o porcentual de votos recebidos por cada partido.

O sistema de lista, porém, apresenta uma maior complexidade para sua implantação. J. M. Nicolau (1999) enumera cinco escolhas que precisam ser feitas para o funcionamento deste sistema:

2. depois da contagem dos votos aplica-se basicamente dois tipos de método para a distribuição das cadeiras: o das maiores médias ${ }^{14}$ e o das maiores sobras $^{15}$;

3. os níveis para a alocação das cadeiras podem ser nacional, onde o cálculo é realizado em um único distrito, que abrange todo o país, ou local, quando a quantidade de cadeiras refere-se aos diversos distritos locais, com diferentes números de representantes;

\footnotetext{
14 "os métodos das maiores médias dividem os votos recebidos pelos partidos por número de série. Feita a divisão, os partidos que obtêm resultados com maiores valores ocupam as cadeiras disputadas" (J. M. Nicolau, 1999, p. 37).

15 "os métodos de maiores sobras operam em dois estágios. O primeiro é o cálculo de uma cota - os votos de cada partido serão divididos por ela - para o cálculo inicial das cadeiras. O segundo é a distribuição das cadeiras não ocupadas no primeiro estágio, e que é feita segundo as maiores sobras de cada partido" (J. M. Nicolau, 1999, p. 42).
} 
4. a cláusula de exclusão, através da qual fica estabelecido o mínimo de votos definidos por lei eleitoral que um partido necessita receber para garantir representação parlamentar. Ela tem por objetivo dificultar o acesso dos pequenos partidos ao legislativo;

5. as regras para a seleção dos candidatos em cada lista, que definem os critérios para distribuição das cadeiras conquistadas pelos partidos entre os candidatos de cada lista, ou seja, quem de cada partido ocupará essas cadeiras ${ }^{16}$.

6. as coligações eleitorais, que permitem que os partidos se unam nas eleições parlamentares. Mantendo sua autonomia organizacional, os partidos apresentam uma lista própria de candidatos nas eleições, mas têm os votos agregados para efeito do cálculo das cadeiras do Legislativo. A soma dos votos dos partidos coligados possibilita que os pequenos partidos tenham mais chances de obter representação.

\subsection{Sistema misto}

Os sistemas mistos combinam, ao mesmo tempo, características dos dois sistemas de representação em eleições para o legislativo. As combinações envolvem, de um lado, algumas formas do sistema proporcional e, de outro, alguma forma do sistema majoritário.

Os sistemas mistos podem ser divididos em dois tipos: de combinação ou de correção, conforme o papel desempenhado pelas cadeiras proporcionais. "No sistema de combinação, as cadeiras eleitas pelo sistema proporcional são independentes das eleitas pelo sistema majoritário. Já no sistema de correção, as cadeiras proporcionais são distribuídas com o objetivo de corrigir as distorções geradas pela parte majoritária“ (Blais e Massicotte apud J. M. Nicolau, 1999, p. 59).

\footnotetext{
16 "A principal distinção nas regras para a seleção de candidatos no sistema de representação proporcional é o grau de influência dos partidos comparado à influência dos eleitores. Em um extremo, no sistema de lista fechada os partidos definem previamente o ordenamento dos candidatos, cabendo os eleitores exclusivamente votar na legenda. Outros modelos permitem algum tipo de intervenção do eleitor na definição de quais candidatos serão eleitos. No sistema de lista aberta e lista livre o ordenamento é definido exclusivamente pelos eleitores. O caso mais complexo é o do sistema de lista flexível, no qual os partidos apresentam uma lista de
} 
O sistema eleitoral misto era utilizado, até muito recentemente, apenas pela Alemanha e pelo México. A partir da década de 1990, o interesse pela combinação dos sistemas proporcionais e majoritários vem crescendo entre os países, levando a reformas nos seus respectivos sistemas eleitorais.

candidatos previamente ordenados, mas também é permitida a intervenção do eleitor" (J. M. Nicolau, 1999, p. 42). 


\section{Anexos}

\section{ANEXo 1}

Doações da Empresa Itaú na Campanha Eleitoral - 2002

\begin{tabular}{|c|c|c|c|c|c|}
\hline UF & Partido & Nome & número & Candidatura & Valor \\
\hline \multicolumn{5}{|c|}{ Doador: Cimento Itaú } & $280.000,00$ \\
\hline MS & PT & $\begin{array}{l}\text { JOSÉ O. MIRANDA DOS } \\
\text { SANTOS }\end{array}$ & 13 & Governador & $250.000,00$ \\
\hline MG & $\mathrm{PL}$ & $\begin{array}{l}\text { RONALDO VASCONCELLOS } \\
\text { NOVAIS }\end{array}$ & 2222 & Deputado Federal & $30.000,00$ \\
\hline
\end{tabular}

\begin{tabular}{|c|c|c|c|c|c|}
\hline UF & Partido & Nome & número & Candidatura & Valor \\
\hline \multicolumn{5}{|c|}{ Doador: Banco Itaú S.A. } & $7.055 .254,68$ \\
\hline BR & PT & $\begin{array}{l}\text { Comitê Financeiro Nacional para } \\
\text { Presidente }\end{array}$ & 4 & & $250.000,00$ \\
\hline BR & PSDB & $\begin{array}{l}\text { Comitê Financeiro Nacional para } \\
\text { Presidente }\end{array}$ & 4 & & $2.200 .000,00$ \\
\hline AM & PSDB & $\begin{array}{l}\text { ARTHUR VIRGILIO DO CARMO } \\
\text { RIBEIRO NETO }\end{array}$ & 451 & Senador & $100.000,00$ \\
\hline $\mathrm{BA}$ & PSDB & JOÃO ALMEIDA DOS SANTOS & 4560 & Deputado Federal & $35.000,00$ \\
\hline $\mathrm{BA}$ & PMDB & BENITO DA GAMA SANTOS & 1519 & Deputado Federal & $40.000,00$ \\
\hline CE & PSDB & $\begin{array}{l}\text { LEONARDO ROSARIO DE } \\
\text { ALCANTARA }\end{array}$ & 4505 & Deputado Federal & $100.000,00$ \\
\hline $\mathrm{DF}$ & PT & $\begin{array}{l}\text { CRISTOVAM RICARDO } \\
\text { CAVALCANTI BUARQUE }\end{array}$ & 133 & Senador & $100.000,00$ \\
\hline GO & PSDB & $\begin{array}{l}\text { RAQUEL FIGUEIREDO } \\
\text { ALESSANDRI TEIXEIRA }\end{array}$ & 4566 & Deputado Federal & $30.000,00$ \\
\hline GO & PSDB & JOVAIR DE OLIVEIRA ARANTES & 4545 & Deputado Federal & $35.000,00$ \\
\hline GO & PFL & VILMAR DA SILVA ROCHA & 2525 & Deputado Federal & $40.000,00$ \\
\hline MA & PFL & JOSE SARNEY FILHO & 2566 & Deputado Federal & $100.000,00$ \\
\hline MG & PSDB & AÉCIO NEVES DA CUNHA & 45 & Governador & $200.000,00$ \\
\hline MG & PPB & $\begin{array}{l}\text { ALBERTO PINTO COELHO } \\
\text { JÚNIOR }\end{array}$ & 11111 & Deputado Estadual & $20.000,00$ \\
\hline MG & PPB & IBRAHIM ABI-ACKEL & 1116 & Deputado Federal & $35.000,00$ \\
\hline MG & PMDB & ANTÔNIO JÚLIO DE FARIA & 15296 & Deputado Estadual & $25.000,00$ \\
\hline MG & PMDB & LUIZ SÁVIO DE SOUZA CRUZ & 15900 & Deputado Estadual & $25.000,00$ \\
\hline MG & PMDB & MARCELLO LIGNANI SIQUEIRA & 1522 & Deputado Federal & $30.000,00$ \\
\hline MG & PMDB & HÉLIO CALIXTO DA COSTA & 150 & Senador & $50.000,00$ \\
\hline MG & $\mathrm{PL}$ & ANDERSON ADAUTO PEREIRA & 2215 & Deputado Federal & $30.000,00$ \\
\hline MG & $\mathrm{PL}$ & $\begin{array}{l}\text { RONALDO VASCONCELLOS } \\
\text { NOVAIS }\end{array}$ & 2222 & Deputado Federal & $30.000,00$ \\
\hline MS & PSDB & $\begin{array}{l}\text { MARISA JOAQUINA MONTEIRO } \\
\text { SERRANO }\end{array}$ & 45 & Governador & $50.000,00$ \\
\hline
\end{tabular}




\begin{tabular}{|c|c|c|c|c|c|}
\hline MS & PMDB & RAMEZ TEBET & 151 & Senador & $150.000,00$ \\
\hline PB & PFL & $\begin{array}{l}\text { MARCONDES IRAN BENEVIDES } \\
\text { GADELHA }\end{array}$ & 2502 & Deputado Federal & $40.000,00$ \\
\hline PE & PPB & RICARDO FERREIRA FIUZA & 1133 & Deputado Federal & $40.000,00$ \\
\hline PE & PMDB & $\begin{array}{l}\text { Comitê Financeiro Estadual para } \\
\text { Governador }\end{array}$ & 8 & & $200.000,00$ \\
\hline PE & PFL & $\begin{array}{l}\text { ANDRÉ CARLOS ALVES DE } \\
\text { PAULA FILHO }\end{array}$ & 2515 & Deputado Federal & $40.000,00$ \\
\hline PE & PFL & $\begin{array}{l}\text { JOEL DE HOLLANDA } \\
\text { CORDEIRO }\end{array}$ & 2526 & Deputado Federal & $40.000,00$ \\
\hline PE & PFL & $\begin{array}{l}\text { MARCO ANTONIO DE OLIVEIRA } \\
\text { MACIEL }\end{array}$ & 256 & Senador & $200.000,00$ \\
\hline $\mathrm{PI}$ & PFL & $\begin{array}{l}\text { JOSE FRANCISCO PAES } \\
\text { LANDIM }\end{array}$ & 2510 & Deputado Federal & $40.000,00$ \\
\hline PR & PDT & JOSÉ MARIA FERREIRA & 12255 & Deputado Estadual & 231,88 \\
\hline PR & PDT & Comitê Financeiro Único & 0 & & $300.000,00$ \\
\hline RJ & PSDB & $\begin{array}{l}\text { MARCIO JOAO DE ANDRADE } \\
\text { FORTES }\end{array}$ & 4550 & Deputado Federal & $100.000,00$ \\
\hline RJ & PMDB & $\begin{array}{l}\text { SERGIO DE OLIVEIRA CABRAL } \\
\text { SANTOS FILHO }\end{array}$ & 155 & Senador & $80.000,00$ \\
\hline RJ & PFL & $\begin{array}{l}\text { RODRIGO FELINTO IBARRA } \\
\text { EPITÁCIO MAIA }\end{array}$ & 2587 & Deputado Federal & $40.000,00$ \\
\hline RN & PTB & $\begin{array}{l}\text { FERNANDO LUIZ GONÇALVES } \\
\text { BEZERRA }\end{array}$ & 14 & Governador & $100.000,00$ \\
\hline RN & PFL & NEY LOPES DE SOUZA & 2512 & Deputado Federal & $40.000,00$ \\
\hline RN & PFL & JOSÉ AGRIPINO MAIA & 252 & Senador & $100.000,00$ \\
\hline RS & PPS & $\begin{array}{l}\text { NELSON LUIZ PROENÇA } \\
\text { FERNANDES }\end{array}$ & 2300 & Deputado Federal & $50.000,00$ \\
\hline RS & PPS & Comitê Financeiro Único & 0 & & $100.000,00$ \\
\hline$R S$ & PPB & Comitê Financeiro Único & 0 & & $500.000,00$ \\
\hline SP & PTB & ARNALDO FARIA DE SA & 1452 & Deputado Federal & $40.000,00$ \\
\hline SP & PTB & LUIZ ANTONIO FLEURY FILHO & 1415 & Deputado Federal & $40.000,00$ \\
\hline SP & PT & $\begin{array}{l}\text { JOSE EDUARDO MARTINS } \\
\text { CARDOZO }\end{array}$ & 1301 & Deputado Federal & $40.000,00$ \\
\hline SP & PSDC & JOSE MARIA EYMAEL & 2727 & Deputado Federal & $40.000,00$ \\
\hline $\mathrm{SP}$ & PSDB & WALTER SHINDI IIHOSHI & 45111 & Deputado Estadual & 22,80 \\
\hline SP & PSDB & $\begin{array}{l}\text { ANDRE FRANCO MONTORO } \\
\text { FILHO }\end{array}$ & 4546 & Deputado Federal & $40.000,00$ \\
\hline SP & PSDB & $\begin{array}{l}\text { ANTONIO CARLOS DE MENDES } \\
\text { THAME }\end{array}$ & 4577 & Deputado Federal & $40.000,00$ \\
\hline SP & PSDB & ARNALDO DE ABREU MADEIRA & 4580 & Deputado Federal & $40.000,00$ \\
\hline SP & PSDB & $\begin{array}{l}\text { JOSÉ ANIBAL PERES DE } \\
\text { PONTES }\end{array}$ & 451 & Senador & $100.000,00$ \\
\hline SP & PSDB & $\begin{array}{l}\text { GERALDO JOSE RODRIGUES } \\
\text { ALCKMIN FILHO }\end{array}$ & 45 & Governador & $150.000,00$ \\
\hline SP & PSDB & $\begin{array}{l}\text { GERALDO JOSE RODRIGUES } \\
\text { ALCKMIN FILHO }\end{array}$ & 45 & Governador & $300.000,00$ \\
\hline SP & PPS & ROMEU TUMA JUNIOR & 23023 & Deputado Estadual & $30.000,00$ \\
\hline SP & PPS & EMERSON KAPAZ & 2332 & Deputado Federal & $40.000,00$ \\
\hline SP & PMDB & FRANCISCO CHICO AMARAL & 15588 & Deputado Estadual & $30.000,00$ \\
\hline
\end{tabular}




\begin{tabular}{|l|l|l|c|l|r} 
SP & PFL & ROBSON TUMA & 2552 & Deputado Federal & $40.000,00$ \\
\hline SP & PFL & $\begin{array}{l}\text { FRANCISCO ANTONIO } \\
\text { SARDELLI }\end{array}$ & 2505 & Deputado Federal & $50.000,00$ \\
\hline SP & PFL & $\begin{array}{l}\text { VALDEMAR CORAUCI } \\
\text { SOBRINHO }\end{array}$ & 2526 & Deputado Federal & $50.000,00$ \\
\hline SP & PFL & GILBERTO KASSAB & 2525 & Deputado Federal & $100.000,00$ \\
\hline SP & PFL & ROMEU TUMA & 252 & Senador & $200.000,00$ \\
\hline
\end{tabular}

\begin{tabular}{|c|c|c|c|c|c|}
\hline UF & Partido & Nome & número & Candidatura & Valor \\
\hline \multicolumn{5}{|c|}{ Doador: ITAUTEC INFORMÁTICA S.A. E ITAUTEC PHLCO S.A. } & $130.999,95$ \\
\hline SP & PSDB & $\begin{array}{l}\text { JULIO FRANCISCO SEMEGHINI } \\
\text { NETO }\end{array}$ & 4555 & Deputado Federal & $104.530,95$ \\
\hline SP & PSDB & $\begin{array}{l}\text { JULIO FRANCISCO SEMEGHINI } \\
\text { NETO }\end{array}$ & 4555 & Deputado Federal & $11.469,00$ \\
\hline $\mathrm{SP}$ & PL & VALDIR PEREIRA DA SILVA & 22677 & Deputado Estadual & $15.000,00$ \\
\hline
\end{tabular}

Fonte: TSE, 2002. 


\section{ANEXo 2}

Doações da ARACRUZ CELULOSE S.A. na Campanha Eleitoral - 2002

\begin{tabular}{|c|c|c|c|c|c|}
\hline UF & Partido & Nome & número & Candidatura & Valor \\
\hline BR & PT & $\begin{array}{l}\text { Comitê Financeiro Nacional para } \\
\text { Presidente }\end{array}$ & 4 & & $50.000,00$ \\
\hline BR & PSDB & $\begin{array}{l}\text { Comitê Financeiro Nacional para } \\
\text { Presidente }\end{array}$ & 4 & & $379.762,63$ \\
\hline \multicolumn{5}{|c|}{ TOTAL - PRESIDENTE } & $429.762,63$ \\
\hline BA & PFL & PAULO GANEM SOUTO & 25 & Governador & $500.000,00$ \\
\hline BA & PFL & $\begin{array}{l}\text { CÉSAR AUGUSTO RABELLO } \\
\text { BORGES }\end{array}$ & 252 & Senador & $50.000,00$ \\
\hline BA & PFL & $\begin{array}{l}\text { ANTONIO CARLOS PEIXOTO DE } \\
\text { MAGALHÃES }\end{array}$ & 251 & Senador & $50.000,00$ \\
\hline BA & PFL & FÁBIO LOUREIRO SOUTO & 2588 & Deputado Federal & $100.000,00$ \\
\hline BA & PFL & $\begin{array}{l}\text { LUIZ ANTONIO } \\
\text { VASCONCELLOS CARREIRA }\end{array}$ & 2599 & Deputado Federal & $80.000,00$ \\
\hline BA & PFL & AROLDO CEDRAZ DE OLIVEIRA & 2550 & Deputado Federal & $50.000,00$ \\
\hline BA & PFL & GERSON SILVA GABRIELLI & 2580 & Deputado Federal & $50.000,00$ \\
\hline BA & PFL & JOSÉ CARLOS ALELUIA COSTA & 2555 & Deputado Federal & $50.000,00$ \\
\hline BA & PFL & JORGE KHOURY HEDAYE & 2552 & Deputado Federal & $50.000,00$ \\
\hline BA & PFL & LUIZ BARBOSA DE DEUS & 25118 & Deputado Estadual & $30.000,00$ \\
\hline BA & PFL & CARLOS RICARDO GABAN & 25101 & Deputado Estadual & $20.000,00$ \\
\hline BA & PFL & HERALDO EDUARDO ROCHA & 25155 & Deputado Estadual & $20.000,00$ \\
\hline BA & PL & SANDRO DE OLIVEIRA REGIS & 22220 & Deputado Estadual & $120.000,00$ \\
\hline BA & PPB & ROBERTO DE OLIVEIRA MUNIZ & 11011 & Deputado Estadual & $20.000,00$ \\
\hline BA & PSDB & JOÃO ALMEIDA DOS SANTOS & 4560 & Deputado Federal & $40.000,00$ \\
\hline BA & PSDB & $\begin{array}{l}\text { JOSÉ LOMANTO CARDOSO DE } \\
\text { MATOS }\end{array}$ & 45670 & Deputado Estadual & $40.000,00$ \\
\hline \multicolumn{5}{|c|}{ TOTAL - BA } & $1.270 .000,00$ \\
\hline ES & PSDB & ADEMIR SANTOS CARDOSO & 4567 & Deputado Federal & $30.000,00$ \\
\hline ES & PDT & ELIAS KIEFER & 1222 & Deputado Federal & $30.000,00$ \\
\hline ES & PFL & $\begin{array}{l}\text { JOSE CARLOS FONSECA } \\
\text { JUNIOR }\end{array}$ & 2522 & Deputado Federal & $120.000,00$ \\
\hline ES & PFL & JOSÉ ESMERALDO DE FREITAS & 25222 & Deputado Estadual & $50.000,00$ \\
\hline ES & PGT & DIRCEU CAVALHERI & 30123 & Deputado Estadual & $50.000,00$ \\
\hline ES & PL & MAGNO PEREIRA MALTA & 222 & Senador & $70.000,00$ \\
\hline ES & PL & ROBSON DE SOUZA VAILLANT & 22333 & Deputado Estadual & $30.000,00$ \\
\hline ES & PL & $\begin{array}{l}\text { CLÁUDIO DE ALMEIDA THIAGO } \\
\text { SOARES }\end{array}$ & 22800 & Deputado Estadual & $20.000,00$ \\
\hline ES & PMDB & GERSON CAMATA & 155 & Senador & $250.000,00$ \\
\hline
\end{tabular}




\begin{tabular}{|c|c|c|c|c|c|}
\hline ES & PMDB & ALBUINO CUNHA DE AZEREDO & 1520 & Deputado Federal & $30.000,00$ \\
\hline ES & PMDB & ESMAEL NUNES LOUREIRO & 15699 & Deputado Estadual & $70.000,00$ \\
\hline ES & PMDB & RUI CARLOS BAROMEU LOPES & 15123 & Deputado Estadual & $60.000,00$ \\
\hline ES & PMDB & JOSÉ BELISÁRIO CORREAA & 15369 & Deputado Estadual & $40.000,00$ \\
\hline ES & PMN & $\begin{array}{l}\text { RAQUEL FERREIRA MAGESTE } \\
\text { LESSA }\end{array}$ & 33233 & Deputado Estadual & $20.000,00$ \\
\hline ES & PPB & MARCUS ANTONIO VICENTE & 1145 & Deputado Federal & $100.000,00$ \\
\hline ES & PPB & $\begin{array}{l}\text { MARIA DE FÁTIMA ROCHA } \\
\text { COUZI }\end{array}$ & 11222 & Deputado Estadual & $80.000,00$ \\
\hline ES & PPB & $\begin{array}{l}\text { ANTONIO CARLOS TONINHO } \\
\text { DE FREITAS }\end{array}$ & 11140 & Deputado Estadual & $70.000,00$ \\
\hline ES & PPB & HERALDO BARBOSA MUSSO & 11190 & Deputado Estadual & $65.000,00$ \\
\hline ES & PPB & GILSON ANTONIO DE SALES & 11110 & Deputado Estadual & $50.000,00$ \\
\hline ES & PPB & LUZIA ALVES TOLEDO & 11500 & Deputado Estadual & $40.000,00$ \\
\hline ES & PPB & $\begin{array}{l}\text { ROSEMARY RODRIGUES DE } \\
\text { LIMA }\end{array}$ & 11123 & Deputado Estadual & $10.000,00$ \\
\hline ES & PPS & RICARDO REZENDE FERRAÇO & 234 & Senador & $100.000,00$ \\
\hline ES & PPS & CÉSAR ROBERTO COLNAGHI & 23456 & Deputado Estadual & $40.000,00$ \\
\hline ES & PPS & Comitê Financeiro Único & 0 & & $100.000,00$ \\
\hline ES & PSB & $\begin{array}{l}\text { PAULO CESAR HARTUNG } \\
\text { GOMES }\end{array}$ & 40 & Governador & $400.000,00$ \\
\hline ES & PSB & $\begin{array}{l}\text { PAULO CESAR HARTUNG } \\
\text { GOMES }\end{array}$ & 40 & Governador & $100.000,00$ \\
\hline ES & PSB & JOSE RENATO CASAGRANDE & 4040 & Deputado Federal & $80.000,00$ \\
\hline ES & PSB & JONES CAVAGLIERI & 4004 & Deputado Federal & $20.000,00$ \\
\hline ES & PSB & LUIZ FERNANDO SCHETTINO & 40123 & Deputado Estadual & $30.000,00$ \\
\hline ES & PSB & MARLUSSE PESTANA DAHER & 40004 & Deputado Estadual & $20.000,00$ \\
\hline ES & PSB & PAULO ALFONSO MENEGUELI & 40400 & Deputado Estadual & $20.000,00$ \\
\hline ES & PSDB & $\begin{array}{l}\text { RICARDO FERREIRA DOS } \\
\text { SANTOS }\end{array}$ & 4512 & Deputado Federal & $120.000,00$ \\
\hline ES & PSDB & ROSILDA DE FREITAS & 4545 & Deputado Federal & $15.000,00$ \\
\hline ES & PSDB & MARIA JOSE VELLOZO LUCAS & 45123 & Deputado Estadual & $70.000,00$ \\
\hline ES & PSDB & ROSANE RIBEIRO MACHADO & 45670 & Deputado Estadual & $10.000,00$ \\
\hline ES & PT & JOÃO CARLOS COSER & 131 & Senador & $70.000,00$ \\
\hline ES & PTB & MAX FREITAS MAURO & 14 & Governador & $200.000,00$ \\
\hline ES & PTB & JOSÉ CARLOS ELIAS & 1414 & Deputado Federal & $120.000,00$ \\
\hline ES & PTB & $\begin{array}{l}\text { ETEVALDA GRASSI DE } \\
\text { MENEZES }\end{array}$ & 14140 & Deputado Estadual & $50.000,00$ \\
\hline ES & PTB & $\begin{array}{l}\text { EUCLERIO DE AZEVEDO } \\
\text { SAMPAIO JUNIOR }\end{array}$ & 14444 & Deputado Estadual & $50.000,00$ \\
\hline ES & PTB & PAULO ROBERTO FERREIRA & 14014 & Deputado Estadual & $30.000,00$ \\
\hline ES & PTB & IZOLINA MARCIA LAMAS SILVA & 14000 & Deputado Estadual & $20.000,00$ \\
\hline \multicolumn{5}{|c|}{ TOTAL - ES } & $2.950 .000,00$ \\
\hline
\end{tabular}




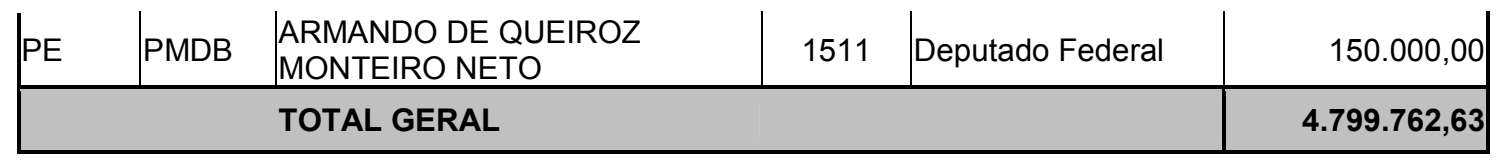

Fonte: TSE, 2002. 


\section{Anexo 3}

Doações da CONSTRUTORA NORBERTO ODEBRECHT S.A. na Campanha Eleitoral - 2002

\begin{tabular}{|c|c|c|c|c|c|}
\hline UF & Partido & Nome & número & Candidatura & Valor \\
\hline BR & PT & LUIZ INACIO LULA DA SILVA & 13 & Presidente & $50.000,00$ \\
\hline BR & PPS & $\begin{array}{l}\text { Comitê Financeiro Nacional para } \\
\text { Presidente }\end{array}$ & 4 & & $500.000,00$ \\
\hline \multicolumn{5}{|c|}{ TOTAL } & $550.000,00$ \\
\hline$A L$ & PSDB & $\begin{array}{l}\text { TEOTONIO BRANDÃO VILELA } \\
\text { FILHO }\end{array}$ & 456 & Senador & $42.000,00$ \\
\hline$A L$ & PSB & $\begin{array}{l}\text { Comitê Financeiro Estadual para } \\
\text { Governador }\end{array}$ & 8 & & $200.000,00$ \\
\hline \multicolumn{5}{|c|}{ TOTAL ESTADUAL } & $242.000,00$ \\
\hline AM & PSDB & $\begin{array}{l}\text { ARTHUR VIRGILIO DO CARMO } \\
\text { RIBEIRO NETO }\end{array}$ & 451 & Senador & $50.000,00$ \\
\hline AM & PSDB & $\begin{array}{l}\text { ARTHUR VIRGILIO DO CARMO } \\
\text { RIBEIRO NETO }\end{array}$ & 451 & Senador & $50.000,00$ \\
\hline \multicolumn{5}{|c|}{ TOTAL ESTADUAL } & $100.000,00$ \\
\hline $\mathrm{BA}$ & PFL & $\begin{array}{l}\text { SONIA MARIA FONTES } \\
\text { MOREIRA }\end{array}$ & 25198 & Deputado Estadual & $5.000,00$ \\
\hline $\mathrm{BA}$ & PRP & JAMIL CHAGOURI OCKÉ & 44789 & Deputado Estadual & $10.000,00$ \\
\hline BA & PFL & $\begin{array}{l}\text { AROLDO CEDRAZ DE } \\
\text { OLIVEIRA }\end{array}$ & 2550 & Deputado Federal & $50.000,00$ \\
\hline$B A$ & PFL & JAIME FERNANDES FILHO & 2505 & Deputado Federal & $20.000,00$ \\
\hline BA & $\mathrm{PL}$ & $\begin{array}{l}\text { EUJÁCIO SIMÕES VIANA } \\
\text { FILHO }\end{array}$ & 2222 & Deputado Federal & $50.000,00$ \\
\hline BA & PSDB & JOÃO ALMEIDA DOS SANTOS & 4560 & Deputado Federal & $100.000,00$ \\
\hline $\mathrm{BA}$ & PTB & MÁRIO SOARES LIMA & 1456 & Deputado Federal & $20.000,00$ \\
\hline BA & PFL & PAULO GANEM SOUTO & 25 & Governador & $1.300 .000,00$ \\
\hline BA & PFL & $\begin{array}{l}\text { CÉSAR AUGUSTO RABELLO } \\
\text { BORGES }\end{array}$ & 252 & Senador & $200.000,00$ \\
\hline BA & PT & Comitê Financeiro Único & 0 & & $150.000,00$ \\
\hline \multicolumn{5}{|c|}{ TOTAL ESTADUAL } & $1.905 .000,00$ \\
\hline CE & PPS & $\begin{array}{l}\text { JOSÉ LEÔNIDAS DE MENEZES } \\
\text { CRISTINO }\end{array}$ & 2345 & Deputado Federal & $50.000,00$ \\
\hline CE & PSDB & $\begin{array}{l}\text { LEONARDO ROSARIO DE } \\
\text { ALCANTARA } \\
\end{array}$ & 4505 & Deputado Federal & $50.000,00$ \\
\hline CE & PSDB & $\begin{array}{l}\text { Comitê Financeiro Estadual para } \\
\text { Governador }\end{array}$ & 8 & & $260.000,00$ \\
\hline CE & PSDB & $\begin{array}{l}\text { Comitê Financeiro Estadual para } \\
\text { Senador }\end{array}$ & 9 & & $90.000,00$ \\
\hline \multicolumn{5}{|c|}{ TOTAL ESTADUAL } & $450.000,00$ \\
\hline DF & PFL & $\begin{array}{l}\text { PAULO OCTAVIO ALVES } \\
\text { PEREIRA }\end{array}$ & 255 & Senador & $20.000,00$ \\
\hline DF & PT & $\begin{array}{l}\text { CRISTOVAM RICARDO } \\
\text { CAVALCANTI BUARQUE }\end{array}$ & 133 & Senador & $75.000,00$ \\
\hline \multicolumn{5}{|c|}{ TOTAL ESTADUAL } & $95.000,00$ \\
\hline ES & PMDB & SÉRGIO MANOEL NADER & 15311 & Deputado Estadual & $50.000,00$ \\
\hline
\end{tabular}




\begin{tabular}{|c|c|c|c|c|c|}
\hline & & BORGES & & & \\
\hline ES & PMN & $\begin{array}{l}\text { DERMIVAL GALVÃO } \\
\text { GONÇALVES }\end{array}$ & 33123 & Deputado Estadual & $20.000,00$ \\
\hline ES & PFL & $\begin{array}{l}\text { JOSE CARLOS FONSECA } \\
\text { JUNIOR }\end{array}$ & 2522 & Deputado Federal & $100.000,00$ \\
\hline \multicolumn{5}{|c|}{ TOTAL ESTADUAL } & $170.000,00$ \\
\hline GO & PSDC & DANIEL AUGUSTO GOULART & 27800 & Deputado Estadual & $50.000,00$ \\
\hline GO & PSDB & $\begin{array}{l}\text { MARCONI FERREIRA PERILLO } \\
\text { JUNIOR }\end{array}$ & 45 & Governador & $150.000,00$ \\
\hline \multicolumn{5}{|c|}{ TOTAL ESTADUAL } & $200.000,00$ \\
\hline MG & PSDB & $\begin{array}{l}\text { AMILCAR VIANNA MARTINS } \\
\text { FILHO }\end{array}$ & 45234 & Deputado Estadual & $20.000,00$ \\
\hline MG & PFL & $\begin{array}{l}\text { JOSÉ SANTANA DE } \\
\text { VASCONCELLOS MOREIRA }\end{array}$ & 2511 & Deputado Federal & $25.000,00$ \\
\hline MG & PFL & LAEL VIEIRA VARELLA & 2505 & Deputado Federal & $20.000,00$ \\
\hline MG & PMDB & $\begin{array}{l}\text { JOÃO LÚCIO MAGALHÃES } \\
\text { BIFANO }\end{array}$ & 1513 & Deputado Federal & $50.000,00$ \\
\hline MG & PMDB & $\begin{array}{l}\text { MARCELLO LIGNANI } \\
\text { SIQUEIRA }\end{array}$ & 1522 & Deputado Federal & $50.000,00$ \\
\hline MG & PMDB & MAURO RIBEIRO LOPES & 1511 & Deputado Federal & $25.000,00$ \\
\hline MG & PPB & IBRAHIM ABI-ACKEL & 1116 & Deputado Federal & $20.000,00$ \\
\hline MG & PPB & $\begin{array}{l}\text { MÁRCIO REINALDO DIAS } \\
\text { MOREIRA }\end{array}$ & 1177 & Deputado Federal & $25.000,00$ \\
\hline MG & PT & ROBERTO MESSIAS FRANCO & 1340 & Deputado Federal & $8.000,00$ \\
\hline MG & PSDB & $\begin{array}{l}\text { EDUARDO BRANDÃO DE } \\
\text { AZEREDO }\end{array}$ & 456 & Senador & $100.000,00$ \\
\hline \multicolumn{5}{|c|}{ TOTAL ESTADUAL } & $343.000,00$ \\
\hline MS & PT & $\begin{array}{l}\text { VANDER LUIZ DOS SANTOS } \\
\text { LOUBET }\end{array}$ & 1331 & Deputado Federal & $100.000,00$ \\
\hline MS & PT & $\begin{array}{l}\text { JOSÉ ORCÍRIO MIRANDA DOS } \\
\text { SANTOS }\end{array}$ & 13 & Governador & $300.000,00$ \\
\hline MS & PT & DELCIDIO AMARAL GOMEZ & 138 & Senador & $45.000,00$ \\
\hline \multicolumn{5}{|c|}{ TOTAL ESTADUAL } & $445.000,00$ \\
\hline PA & PSB & ADEMIR GALVÃO ANDRADE & 40 & Governador & $100.000,00$ \\
\hline PA & PTB & $\begin{array}{l}\text { HILDEGARDO DE FIGUEIREDO } \\
\text { NUNES }\end{array}$ & 14 & Governador & $100.000,00$ \\
\hline PA & PSB & Comitê Financeiro Único & 0 & & $100.000,00$ \\
\hline PA & PTB & Comitê Financeiro Único & 0 & & $100.000,00$ \\
\hline \multicolumn{5}{|c|}{ TOTAL ESTADUAL } & $400.000,00$ \\
\hline PB & PSDB & INALDO ROCHA LEITÃO & 4545 & Deputado Federal & $100.000,00$ \\
\hline PB & PSDB & $\begin{array}{l}\text { CASSIO RODRIGUES DA } \\
\text { CUNHA LIMA }\end{array}$ & 45 & Governador & $100.000,00$ \\
\hline \multicolumn{5}{|c|}{ TOTAL ESTADUAL } & $200.000,00$ \\
\hline PE & PFL & $\begin{array}{l}\text { AUGUSTO RODRIGUES } \\
\text { COUTINHO DE MELO }\end{array}$ & 25155 & Deputado Estadual & $50.000,00$ \\
\hline PE & PFL & $\begin{array}{l}\text { MARCO AURELIO DE } \\
\text { MEDEIROS LIMA }\end{array}$ & 25123 & Deputado Estadual & $10.000,00$ \\
\hline PE & PMDB & RAUL JEAN LOUIS HENRY & 15999 & Deputado Estadual & $50.000,00$ \\
\hline
\end{tabular}




\begin{tabular}{|c|c|c|c|c|c|}
\hline & & JUNIOR & & & \\
\hline$P E$ & PPB & $\begin{array}{l}\text { HENRIQUE JOSÉ QUEIROZ } \\
\text { COSTA }\end{array}$ & 11160 & Deputado Estadual & $10.000,00$ \\
\hline $\mathrm{PE}$ & PPB & MANOEL FERREIRA DA SILVA & 11166 & Deputado Estadual & $10.000,00$ \\
\hline $\mathrm{PE}$ & PPS & RANILSON BRANDÃO RAMOS & 23456 & Deputado Estadual & $10.000,00$ \\
\hline $\mathrm{PE}$ & PSB & $\begin{array}{l}\text { JOÃO FERNANDO PONTUAL } \\
\text { COUTINHO }\end{array}$ & 40140 & Deputado Estadual & $10.000,00$ \\
\hline $\mathrm{PE}$ & PSB & $\begin{array}{l}\text { JOSÉ AUGUSTO CAVALCANTI } \\
\text { DE FARIAS }\end{array}$ & 40456 & Deputado Estadual & $20.000,00$ \\
\hline $\mathrm{PE}$ & PSDB & $\begin{array}{l}\text { BRUNO CAVALCANTI DE } \\
\text { ARAÚJO }\end{array}$ & 45111 & Deputado Estadual & $15.000,00$ \\
\hline $\mathrm{PE}$ & PSDC & ADELMO DUARTE RIBEIRO & 27777 & Deputado Estadual & $50.000,00$ \\
\hline $\mathrm{PE}$ & PSDC & $\begin{array}{l}\text { AUGUSTINHO RUFINO DE } \\
\text { MELO }\end{array}$ & 27111 & Deputado Estadual & $50.000,00$ \\
\hline $\mathrm{PE}$ & PFL & $\begin{array}{l}\text { JOAQUIM FRANCISCO DE } \\
\text { FREITAS CAVALCANTI }\end{array}$ & 2550 & Deputado Federal & $50.000,00$ \\
\hline $\mathrm{PE}$ & PFL & OSVALDO DE SOUZA COELHO & 2530 & Deputado Federal & $20.000,00$ \\
\hline $\mathrm{PE}$ & PMDB & JOSÉ SEVERIANO CHAVES & 1555 & Deputado Federal & $40.000,00$ \\
\hline$P E$ & PMDB & SALATIEL SOUZA CARVALHO & 1544 & Deputado Federal & $40.000,00$ \\
\hline $\mathrm{PE}$ & PPS & $\begin{array}{l}\text { ROBERTO JOÃO PEREIRA } \\
\text { FREIRE }\end{array}$ & 2323 & Deputado Federal & $100.000,00$ \\
\hline $\mathrm{PE}$ & PSB & LUIZ GONZAGA PATRIOTA & 4000 & Deputado Federal & $10.000,00$ \\
\hline $\mathrm{PE}$ & PSDB & $\begin{array}{l}\text { JOSÉ MÚCIO MONTEIRO } \\
\text { FILHO }\end{array}$ & 4590 & Deputado Federal & $70.000,00$ \\
\hline $\mathrm{PE}$ & PFL & $\begin{array}{l}\text { MARCO ANTONIO DE } \\
\text { OLIVEIRA MACIEL }\end{array}$ & 256 & Senador & $100.000,00$ \\
\hline $\mathrm{PE}$ & PMDB & $\begin{array}{l}\text { Comitê Financeiro Estadual para } \\
\text { Governador }\end{array}$ & 8 & & $311.000,00$ \\
\hline TO & ESTADU & AL & & & $1.026 .000,00$ \\
\hline RJ & PFL & $\begin{array}{l}\text { EIDER RIBEIRO DANTAS } \\
\text { FILHO }\end{array}$ & 25123 & Deputado Estadual & $50.000,00$ \\
\hline RJ & PFL & $\begin{array}{l}\text { JOÃO PEDRO CAMPOS DE } \\
\text { ANDRADE FIGUEIRA }\end{array}$ & 25001 & Deputado Estadual & $20.000,00$ \\
\hline RJ & PSB & BERNARD RAJZMAN & 40111 & Deputado Estadual & $10.000,00$ \\
\hline RJ & PSB & JAMIL HADDAD & 40140 & Deputado Estadual & $20.000,00$ \\
\hline RJ & PSB & $\begin{array}{l}\text { RAYMUNDO THEODORO } \\
\text { CARVALHO DE OLIVEIRA }\end{array}$ & 40821 & Deputado Estadual & $10.000,00$ \\
\hline RJ & PSDB & $\begin{array}{l}\text { RONALDO CHAER DO } \\
\text { NASCIMENTO }\end{array}$ & 45007 & Deputado Estadual & $75.000,00$ \\
\hline RJ & PV & $\begin{array}{l}\text { ANDRE GUSTAVO PEREIRA } \\
\text { CORREA DA SILVA }\end{array}$ & 43123 & Deputado Estadual & $50.000,00$ \\
\hline RJ & PC do B & JANDIRA FEGHALI & 6565 & Deputado Federal & $12.000,00$ \\
\hline RJ & PMDB & $\begin{array}{l}\text { WAGNER HUCKLEBERRY } \\
\text { SIQUEIRA }\end{array}$ & 1516 & Deputado Federal & $10.000,00$ \\
\hline RJ & PMDB & $\begin{array}{l}\text { WELLINGTON MOREIRA } \\
\text { FRANCO }\end{array}$ & 1515 & Deputado Federal & $50.000,00$ \\
\hline RJ & PSB & $\begin{array}{l}\text { ALEXANDRE AGUIAR } \\
\text { CARDOSO }\end{array}$ & 4040 & Deputado Federal & $50.000,00$ \\
\hline RJ & PSB & JOSIAS QUINTAL DE OLIVEIRA & 4010 & Deputado Federal & $25.000,00$ \\
\hline RJ & PSB & $\begin{array}{l}\text { LUIZ HENRIQUE MORAES DE } \\
\text { LIMA }\end{array}$ & 4001 & Deputado Federal & $75.000,00$ \\
\hline
\end{tabular}




\begin{tabular}{|c|c|c|c|c|c|}
\hline RJ & PT & $\begin{array}{l}\text { LUIZ SÉRGIO NÓBREGA DE } \\
\text { OLIVEIRA }\end{array}$ & 1312 & Deputado Federal & $20.000,00$ \\
\hline RJ & PFL & SOLANGE AMARAL & 25 & Governador & $1.000,00$ \\
\hline RJ & PT & $\begin{array}{l}\text { BENEDITA SOUZA DA SILVA } \\
\text { SAMPAIO }\end{array}$ & 13 & Governador & $100.000,00$ \\
\hline \multicolumn{5}{|c|}{ TOTAL ESTADUAL } & $578.000,00$ \\
\hline RN & PFL & NEY LOPES DE SOUZA & 2512 & Deputado Federal & $30.000,00$ \\
\hline RN & PSB & WILMA MARIA DE FARIA & 40 & Governador & $170.000,00$ \\
\hline $\mathrm{RN}$ & PMDB & GARIBALDI ALVES FILHO & 154 & Senador & $50.000,00$ \\
\hline \multicolumn{5}{|c|}{ TOTAL ESTADUAL } & $250.000,00$ \\
\hline SC & PPB & ANTONIO CARLOS VIEIRA & 11147 & Deputado Estadual & $30.000,00$ \\
\hline SC & PFL & GERVÁSIO JOSÉ DA SILVA & 2580 & Deputado Federal & $20.000,00$ \\
\hline SC & PMDB & EDSON BEZ DE OLIVEIRA & 1515 & Deputado Federal & $50.000,00$ \\
\hline SC & PMDB & LUIZ HENRIQUE DA SILVEIRA & 15 & Governador & $50.000,00$ \\
\hline \multicolumn{5}{|c|}{ TOTAL ESTADUAL } & $150.000,00$ \\
\hline SE & PMDB & $\begin{array}{l}\text { JORGE ALBERTO TELES } \\
\text { PRADO }\end{array}$ & 1555 & Deputado Federal & $50.000,00$ \\
\hline \multicolumn{5}{|c|}{ TOTAL ESTADUAL } & $50.000,00$ \\
\hline SP & PPB & $\begin{array}{l}\text { ANTONIO DE SOUSA } \\
\text { RAMALHO }\end{array}$ & 11233 & Deputado Estadual & $10.000,00$ \\
\hline SP & PPB & $\begin{array}{l}\text { ANTONIO DE SOUSA } \\
\text { RAMALHO }\end{array}$ & 11233 & Deputado Estadual & $10.000,00$ \\
\hline SP & PSDB & $\begin{array}{l}\text { ANTONIO DUARTE NOGUEIRA } \\
\text { JUNIOR }\end{array}$ & 45155 & Deputado Estadual & $10.000,00$ \\
\hline SP & $\mathrm{PL}$ & $\begin{array}{l}\text { LUIZ ANTONIO DE MEDEIROS } \\
\text { NETO }\end{array}$ & 2277 & Deputado Federal & $30.000,00$ \\
\hline SP & PPS & EMERSON KAPAZ & 2332 & Deputado Federal & $50.000,00$ \\
\hline SP & PPS & JOÃO HERRMANN NETO & 2323 & Deputado Federal & $20.000,00$ \\
\hline SP & PSDB & $\begin{array}{l}\text { ALOYSIO NUNES FERREIRA } \\
\text { FILHO }\end{array}$ & 4521 & Deputado Federal & $100.000,00$ \\
\hline SP & PSDB & MARCO VINICIO PETRELLUZZI & 4520 & Deputado Federal & $50.000,00$ \\
\hline$S P$ & PSDC & JOSE MARIA EYMAEL & 2727 & Deputado Federal & $20.000,00$ \\
\hline SP & PSDB & $\begin{array}{l}\text { GERALDO JOSE RODRIGUES } \\
\text { ALCKMIN FILHO }\end{array}$ & 45 & Governador & $125.000,00$ \\
\hline \multicolumn{5}{|c|}{ TOTAL ESTADUAL } & $425.000,00$ \\
\hline \multicolumn{5}{|c|}{ TOTAL } & $7.579 .000,00$ \\
\hline
\end{tabular}

Fonte: TSE, 2002. 


\section{ANEXO 4}

Doações da CONSTRUTORA NORBERTO ODEBRECHT S.A. na Campanha Eleitoral - 2002

\begin{tabular}{|c|c|c|c|}
\hline Partido & UF & Candidatura & Valor \\
\hline $\mathrm{PC}$ do $\mathrm{B}$ & RJ & Deputado Federal & $12.000,00$ \\
\hline \multicolumn{3}{|l|}{ TOTAL - PC do B } & $12.000,00$ \\
\hline PFL & BA & Deputado Estadual & $5.000,00$ \\
\hline PFL & BA & Deputado Federal & $50.000,00$ \\
\hline PFL & BA & Deputado Federal & $20.000,00$ \\
\hline PFL & BA & Governador & $1.300 .000,00$ \\
\hline \multirow[t]{2}{*}{ PFL } & BA & Senador & $200.000,00$ \\
\hline & & & $1.575 .000,00$ \\
\hline \multirow[t]{2}{*}{ PFL } & DF & Senador & $20.000,00$ \\
\hline & & & $20.000,00$ \\
\hline \multirow[t]{2}{*}{ PFL } & ES & Deputado Federal & $100.000,00$ \\
\hline & & & $100.000,00$ \\
\hline PFL & MG & Deputado Federal & $25.000,00$ \\
\hline \multirow[t]{2}{*}{ PFL } & MG & Deputado Federal & $20.000,00$ \\
\hline & & & $45.000,00$ \\
\hline \multirow[t]{2}{*}{ PFL } & PE & Deputado Estadual & $50.000,00$ \\
\hline & PE & Deputado Estadual & $10.000,00$ \\
\hline PFL & PE & Deputado Federal & $50.000,00$ \\
\hline PFL & PE & Deputado Federal & $20.000,00$ \\
\hline \multirow[t]{2}{*}{ PFL } & PE & Senador & $100.000,00$ \\
\hline & & & $230.000,00$ \\
\hline PFL & RJ & Deputado Estadual & $50.000,00$ \\
\hline PFL & RJ & Deputado Estadual & $20.000,00$ \\
\hline \multirow[t]{2}{*}{ PFL } & RJ & Governador & $1.000,00$ \\
\hline & & & $71.000,00$ \\
\hline \multirow[t]{2}{*}{ PFL } & RN & Deputado Federal & $30.000,00$ \\
\hline & & & $30.000,00$ \\
\hline \multirow[t]{2}{*}{ PFL } & SC & Deputado Federal & $20.000,00$ \\
\hline & & & $20.000,00$ \\
\hline \multicolumn{3}{|l|}{ TOTAL - PFL } & $2.091 .000,00$ \\
\hline $\mathrm{PL}$ & BA & Deputado Federal & $50.000,00$ \\
\hline PL & SP & Deputado Federal & $30.000,00$ \\
\hline
\end{tabular}




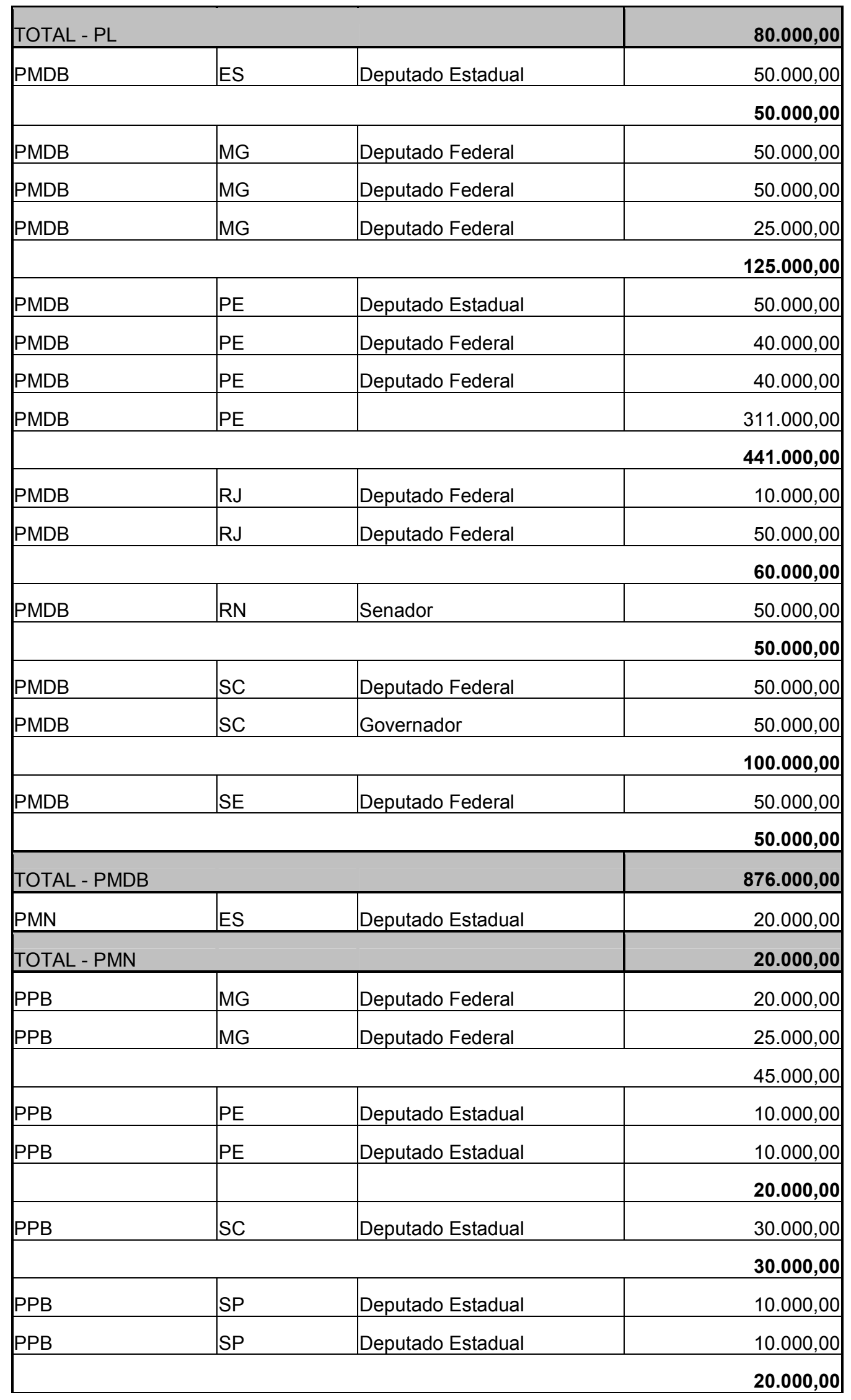




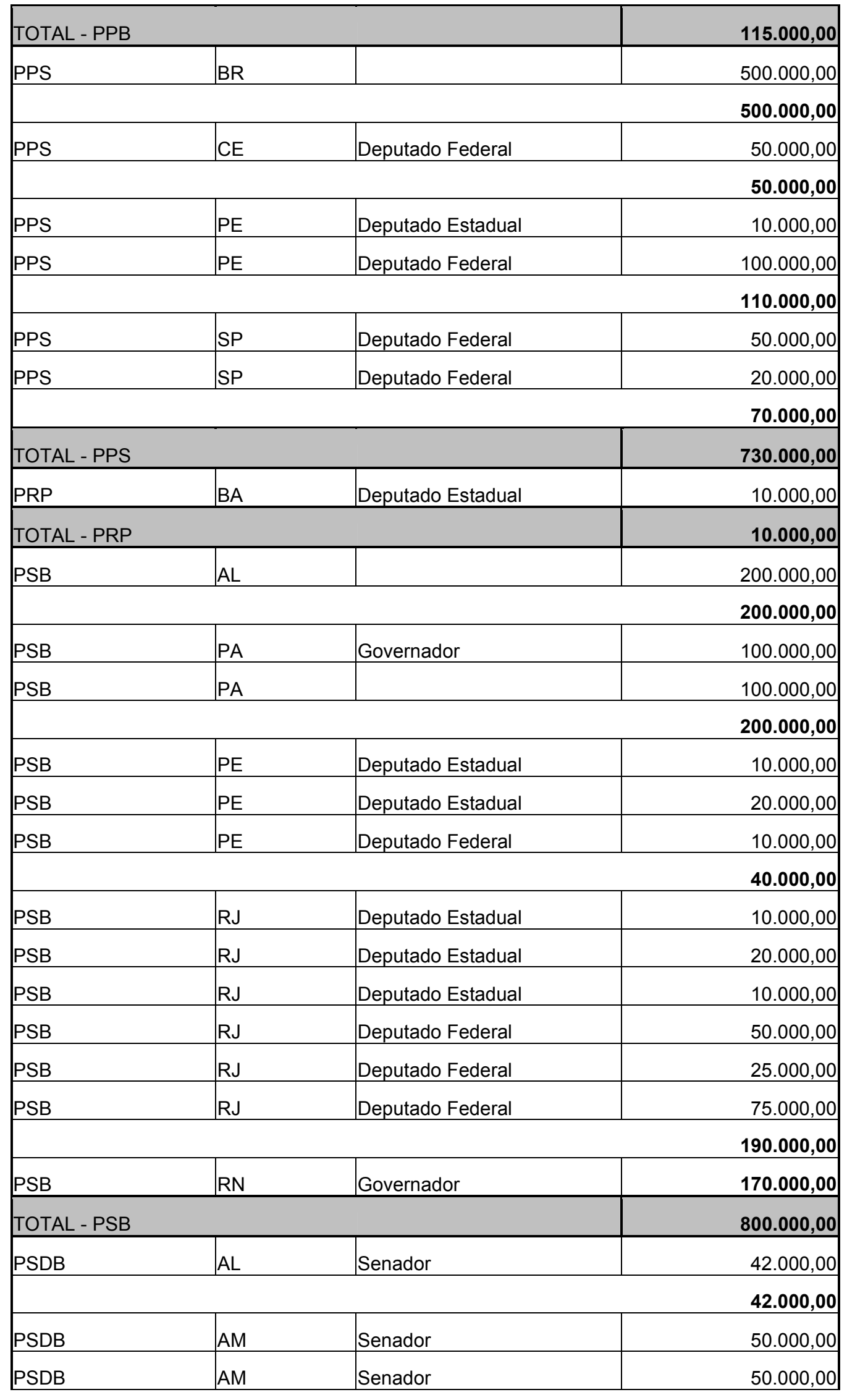




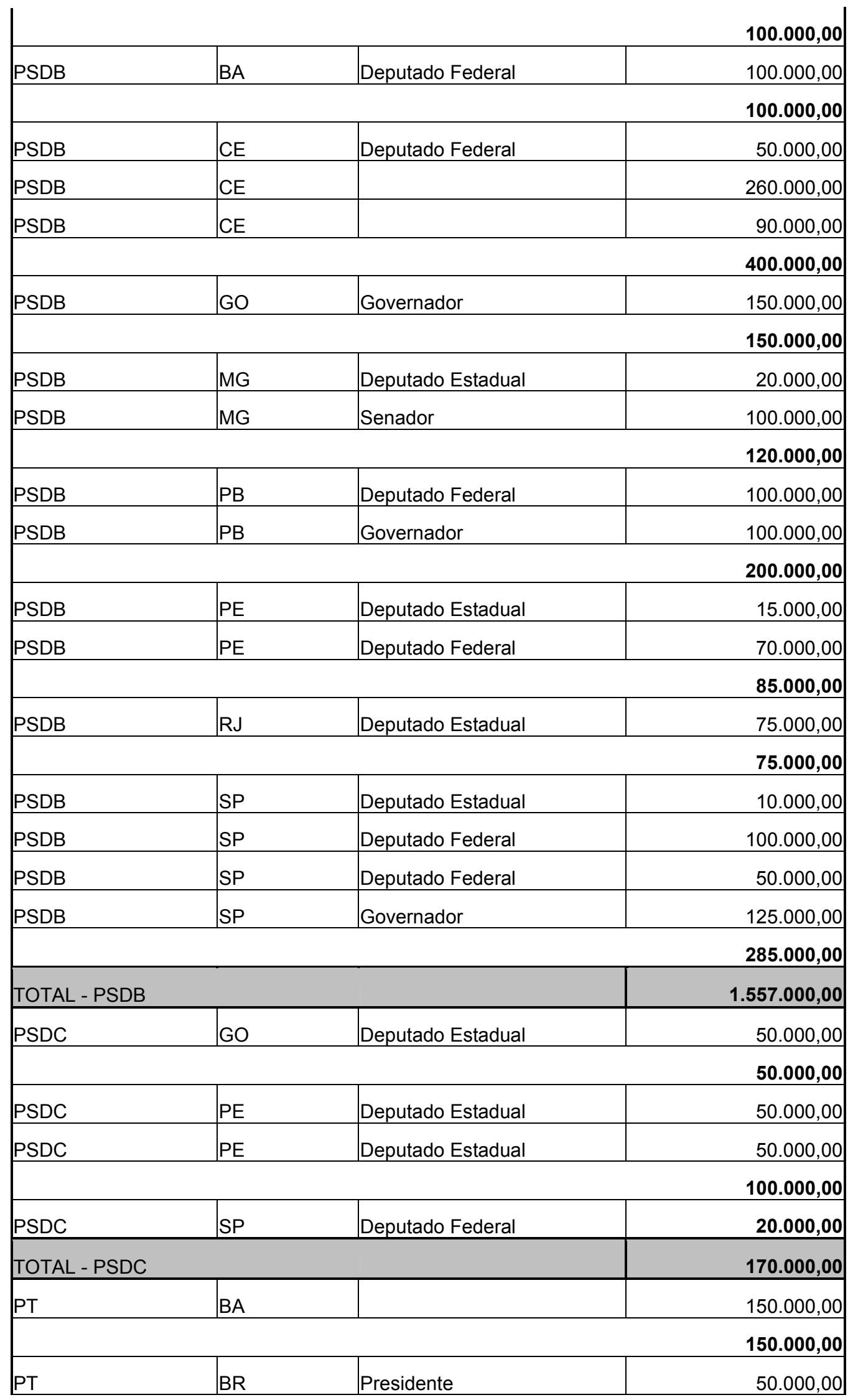




\begin{tabular}{|c|c|c|c|}
\hline PT & DF & Senador & $75.000,00$ \\
\hline & & & $75.000,00$ \\
\hline PT & MG & Deputado Federal & $8.000,00$ \\
\hline & & & $8.000,00$ \\
\hline PT & MS & Deputado Federal & $100.000,00$ \\
\hline PT & MS & Governador & $300.000,00$ \\
\hline PT & MS & Senador & $45.000,00$ \\
\hline & & & $445.000,00$ \\
\hline PT & RJ & Deputado Federal & $20.000,00$ \\
\hline PT & RJ & Governador & $100.000,00$ \\
\hline & & & $120.000,00$ \\
\hline TOTAL - PT & & & $848.000,00$ \\
\hline PTB & BA & Deputado Federal & $20.000,00$ \\
\hline & & & $20.000,00$ \\
\hline PTB & PA & Governador & $100.000,00$ \\
\hline PTB & PA & & $100.000,00$ \\
\hline & & & $200.000,00$ \\
\hline TOTAL - PTB & & & $220.000,00$ \\
\hline PV & RJ & Deputado Estadual & $50.000,00$ \\
\hline TOTAL - PV & & & $50.000,00$ \\
\hline TOTAL & & & $7.579 .000,00$ \\
\hline
\end{tabular}

Fonte: TSE, 2002. 